\title{
PHRQINPT-AN INTERACTIVE COMPUTER PROGRAM FOR CONSTRUCTING INPUT DATA SETS TO THE GEOCHEMICAL SIMULATION PROGRAM PHREEQE
}

By G.W. Fleming and L.N. Plummer

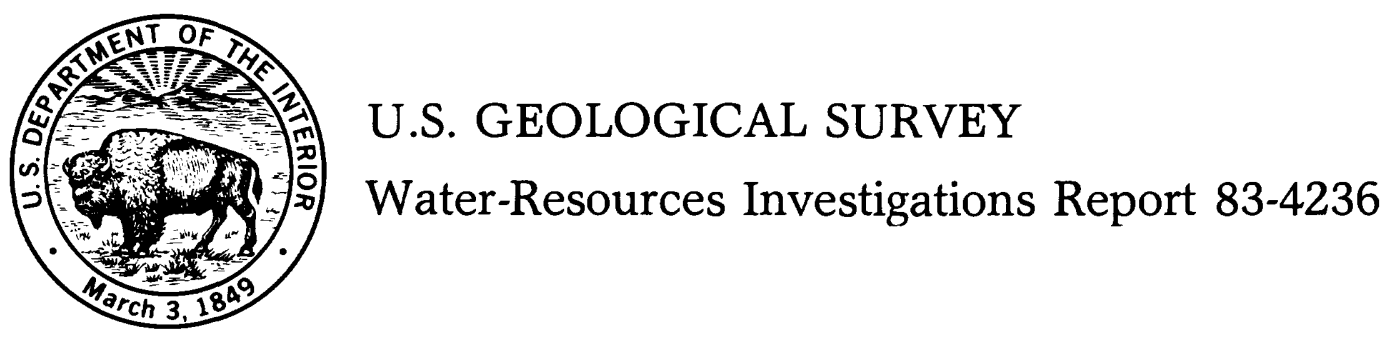

1983 


\author{
UNITED STATES DEPARTMENT OF THE INTERIOR \\ WILLIAM P. CLARK, Secretary \\ GEOLOGICAL SURVEY \\ Dallas L. Peck, Director
}

For additional information write to:

Chief Hydrologist

U.S. Geological Survey

National Center, Mail Stop 432

Reston, Virginia 22092
Copies of this report can be purchased from:

Open-File Services Section Western Distribution Branch U.S. Geological Survey Box 25425, Federal Center Denver, Colorado 80225

Requests, at cost, for the source code and data files listed in Attachments $D, E$, and $F$ should be directed to: U.S. Geological Survey, Office of Program Support Services, 802 National Center, Reston, VA 22092.

A blank tape should accompany your request. 


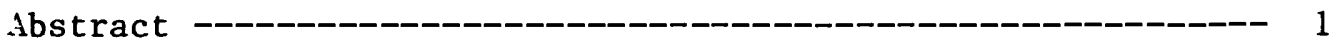

Introduction --_-_-_-_-_-_-_-_-_-_-_-_-_-_-_-_-_-_--- 1

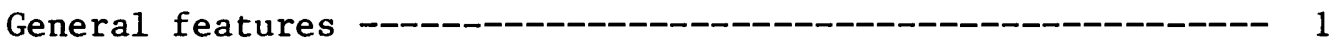

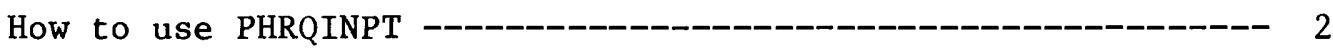

Adapting PHRQINPT to other systems --_-_-_-_---_---_----- 4

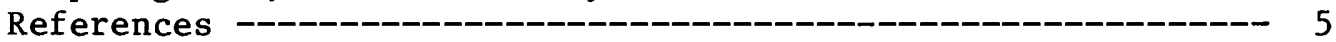

Attachment A - Description of input variables to

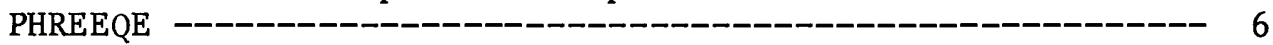

Attachment B - Example using PHRQINPT to construct input data set a priori ----_--- 30

Attachment C - Example using PHRQINPT to modify an

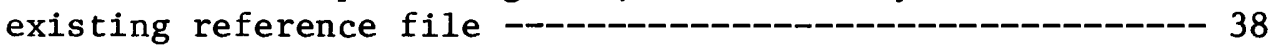

Attachment D - Source code listing of PHRQINPT -------------- 47

Attachment E - Minerals file read by PHRQINPT as

logical file unit 11 ---_---_--- 93

Attachment $F$ - PHREEQE data file read by PHRQINPT

as logical file unit 12 -- 96 
PHRQINPT is a FORTRAN 77 program that facilitates formulation of the input data file to PHREEQE (Parkhurst, Thorstenson, and Plummer, 1980). PHRQINPT runs interactively and contains many features to help the user construct the input data set. This report describes these features and gives instructions on the use and implementation of PHRQINPT. A listing of the program and the two accompanying data sets are given in the Attachments, along with two examples.

\section{INTRODUCTION}

After publication of the program PHREEQE (Parkhurst, Thorstenson, and Plummer, 1980)*, it became apparent that construction of the input file to PHREEQE is of ten tedious and subject to user error. With this in mind, PHRQINPT was written to relieve these problems.

GENERAL FEATURES

PHRQINPT, written in Prime Fortran 77, interactively asks the user at the terminal for values of variables required by PHREEQE (Attachment A describes the input required by PHREEQE as given by Parkhurst, Thorstenson, and Plummer, 1980), explains the meaning and significance of each variable when required, and internally checks to make sure that values entered are valid. In some cases, PHRQINPT automatically assigns values to certain variables, based on values previously entered, and keeps track of additional required information. PHRQINPT contains an editor which allows the user to correct mistakes after each line has been completed.

\footnotetext{
*For the reader unfamiliar with PHREEQE, this FORTRAN 77 code is capable of simulating the outcome of real or hypothetical chemical reactions (both reversible and irreversible) under a wide variety of physico-chemical conditions of interest in the earth sciences.
} 
Two data files are used by PHRQINPT. One is a table of preconstructed MINERALS input cards from which the user may select by mineral number listed on the screen. This mineral list may be displayed using the command LIST during MINERALS input. The other file read by PHRQINPT is the thermodynamic data file of PHREEQE, which provides a list of master species, master elements, their charges and appropriate index numbers. In addition to these two files, the user also can specify an optional reference file. The optional reference file contains an existing PHREEQE input data set that the user may copy and/or modify through PHRQINPT and then write the updated PHREEQE input data set to a different file.

HOW TO USE PHRQINPT

This program was written so that the user should be able to run it with no outside information other than knowledge of the desired geochemical simulation. Basic understanding of the program PHREEQE is helpful, though not necessary. The interested reader is referred to several recent reports (Parkhurst, Thorstenson, Plummer, 1980; Plummer, Parkhurst, and Thorstenson, 1983). For those who are running this program for the first time, the following information should be helpful:

The program will recognize commands in either upper or lower case.

A11 input values are free-formated. Therefore, numbers do not need to be right justified.

All files are opened within the program. The program will first ask for the output file name and name of a reference file. This reference file name, if given, must be the name of an existing data file previously coded to be read by PHREEQE. The reference file may contain more than one simulation. If one does not wish to use a reference file, simply enter a carriage return.

Caution: When copying directly from a reference file, the program assumes that the reference file is correct and does not check the values of variables. 
Help messages are automatically printed whenever the value entered is of the wrong format, not within the correct range, or a '?' is entered. In addition to the help messages, a list of preconstructed minerals and a list of master elements/species is available at certain locations within the program, which are indicated in the help messages.

The program PHRQINPT stores all values in memory, and does not write them into the output file until the end of the session. Because of this, the PHREEQE data blocks (cf. Attachment A) SOLUTION, ELEMENTS, SPECIES, MINERALS, LOOK MIN, and SUMS can be called more than once. New entries are simply attached to the end of the block. The program also keeps track of entries to make sure that there is no duplication; and recognizes for every master species entered, a master element must also be entered.

At the completion of each card, the user is asked (answer Yes, $\mathrm{Y}$; No, N) whether the values on the card are satisfactory. If the user answers Yes, all values on that card are assumed completely correct and may no longer be changed in the current session. If the user answers No, the program goes into the correction mode by reprinting the values one at a time and asks the user for correct values. Previously correct values are retained by keying a carriage return, after each value appears on the system.

The last keyword command required by PHREEQE is END. If the user entered 'END' and has not entered all required information, the program will inform the user of this fact and will list the remaining required keywords. Until these are entered, the program can not be exited normally.

The order that keyword data blocks are entered is not necessarily the order that is printed in the output file. Instead, PHRQINPT writes the data blocks to the output file in the order preferred for PHREEQE.

If one accidentally entered a wrong keyword, that keyword data block can be aborted by entering 'exit' during the first question of that keyword block.

During modification of an existing reference file, the user may choose to keep, delete, or modify keyword data blocks as they appear on the screen. Extra data blocks may be inserted by answering delete when PHRQINPT recalls the 'END' card from the reference file. 
If one does so, the program at this point then behaves as if there were no reference file at all and will ask the user for the name of a keyword.

At the conclusion of each simulation, the user has several options: (1) stop, (2) continue with the next simulation on the optional reference file (if it exists), (3) define a new reference file, (4) define the previous output as the new reference, or (5) just continue on entering values without a reference file. All further input to PHRQINPT will be appended to the same output file during a single session.

As examples of the use of PHRQINPT, Attachment $B$ is a record of an interactive terminal session in which a PHREEQE input data set was constructed a priori. Attachment $C$ records a session in which the previously constructed data set of Attachment $B$ is modified. Attachment D contains a listing of the PHRQINPT source code and Attachments $\mathrm{E}$ and $\mathrm{F}$ 1ist the data files required by PHREEQE .

\section{ADAPTING PHRQINPT TO OTHER SYSTEMS}

The program is written in Prime Fortran $77^{a}$. In transporting the program to another computer, several changes may be required:

Logical file 1 , which is assigned to the terminal during input/output, may need to be changed.

Open statements may need to be changed to adapt to the different convention of file naming.

Internal reads, "read (STRING, . . .)", may or may not be supported. Buffer-In statements can be substituted.

Long format statements may need to be broken down into several shorter ones.

a Mention of brand name in this report is for identification purposes only and does not constitute endorsement by the U.S. Geological Survey. 
Because of the unusually large number of dynamic variables in the program, procedures may be needed to ensure that it will run properly. On the Prime computer, this problem can be avoided by compiling PHRQINPT with the -save option, making the variables static. Because many of the variables are used in CALL statements, they should not be placed in COMMON.

\section{REFERENCES}

Parkhurst, D. L., Thorstenson, D. C., and Plummer, L. N., 1980, PHREEQE-A computer program for geochemical calculations:

U.S. Geological Survey Water-Resources Investigations 80-96, 210 p., National Technical Information Services Report

PB 81-167 801, Springfie1d, VA 22161 .

Plumer, L. N., Parkhurst, D. L., and Thorstenson, D. C., 1983, Development of reaction models for ground-water systems: Geochimica et Cosmochimica Acta, v. 47, p. 665-686. 
Attachment A. - Description of input variables to PHREEQE

(From Parkhurst, Thorstenson, and Plummer, 1980) 
PHREEQE is designed to perform a sequence of simulations in a single computer run. Each simulation consists of two separate problems:

1. Process an initial solution or solutions and

2. Model a reaction (starting from the initial solution(s)).

Many pathways for a simulation are accessable with a card input data deck; that is, no program modification should be necessary. Required input begins with a title card followed by an option card. Depending on the options selected, additional data are supplied using various "Keyword" data blocks. A data block consists of a Keyword card followed by appropriate data. The Keyword informs the program of the type and format of the data to follow. ELEMENTS and SPECIES, if they are used, should be the first two data blocks while the other keyword blocks may follow in any order. The keyword END denotes the end of the input data and is required once for each simulation. After the calculations for one simulation are completed, the program starts the data input process again, beginning with a new title and option card.

The general types of reactions that can be simulated are as follows:

1. Mixing of two solutions.

2. Titrating one solution with a second solution.

3. Adding or subtracting a net stoichiometric reaction (changing total concentrations of elements in proportion to a given stoichiometry).

4. Adding a net stoichiometric reaction until the phase boundary of a specified mineral is reached.

5. Equilibrating with mineral phases (mineral equilibrium can be specified with reaction types $1,2,3,4$, or 6 as wel1). Any condition which can be written in the form

$$
\log \left(k_{p}\right)=\sum_{i} b_{p, i} \cdot \log \left(a_{i}\right)
$$

where

$$
\begin{aligned}
& a_{i} \text { is activity of the } i^{\text {th }} \text { aqueous species, } \\
& b_{p, i} \text { is the stoichiometric coefficient of the }
\end{aligned}
$$




$$
\begin{aligned}
& i^{\text {th }} \text { aqueous species in the } \mathrm{p}^{\text {th }} \\
& \text { phase, and } \\
& \mathrm{K}_{\mathrm{p}} \text { is the equilibrium constant for the } \\
& \mathrm{p}^{\text {th }} \text { phase, }
\end{aligned}
$$

is considered a mineral phase. This definition of mineral equilibrium includes the following:

a. Maintaining the aqueous phase in equilibrium with one or more minerals, such as calcite, $\mathrm{Fe}(\mathrm{OH})_{3}$, or gypsum;

b. Equilibration of a mineral-water system with a gas $\left(\mathrm{CO}_{2}, \mathrm{CH}_{4}, \mathrm{H}_{2} \mathrm{~S}\right)$;

c. Apparent ion exchange in the sense that a ratio of two aqueous ion activities is kept constant.

Any combination of the above can be included in the MINERALS keyword input provided the Gibbs Phase Rule is not violated.

\section{Changing temperature.}

These six types of reaction (processes) may be used in various combinations. For example, one could add a net stoichiometric reaction to a starting solution while maintaining mineral equilibrium and increasing temperature.

In each type of reaction, an initial solution must be specified. There are three ways to provide a starting solution for a reaction. (1) The total concentrations of elements (and other necessary information such as $\mathrm{pH}$, and temperature) may be input using the SOLUTION $\mathrm{n}$ keyword. $n$ is either 1 or 2 and indicates the number of the array where the solution data will be stored. Any stoichiometric reaction or simple mineral equilibration is performed on solution number 1 alone. Solution number 2 is required only for mixing and titrating. (2) The second method of providing a starting solution for a reaction is to save the final solution from the reaction step of the previous simulation (provided more than one simulation is made in a run). IOPT( 7 ) is used to specify the solution number into which the final solution will be saved. In the subsequent simulation no new solution should be read into that solution number. (3) Finally, if no reaction solution is saved and no new solutions are input, the solutions from the previous simulation remain in memory. Thus, a solution can be input once but can be used as the starting solution for several simulations. 
One of the principle applications of PHREEQE is intended to be simulation of reactions based on observed water analyses, which will generally show an apparent electrical imbalance as a result of analytical errors. Because we use the electrical neutrality criterion in solving for $\mathrm{pH}$, it is important to consider this apparent charge imbalance. Various options are available to achieve charge balance or to maintain a charge imbalance in the computations. Care should be taken in choosing the appropriate option and interpreting the results. Only perfect chemical analyses would produce electrical neutrality in an initial solution. Lacking these, the solution may be left electrically unbalanced by setting $\operatorname{IOPT}(2)=0$. When a reaction is modeled the final calculated solution will have the same electrical imbalance as the initial solution. If $\operatorname{IOPT}(2)=1$, the $\mathrm{pH}$ of the initial solution will be adjusted to produce electrical neutrality in that solution. It may be that the $\mathrm{pH}$ of the initial solution is well known and it is more reasonable to add relatively inert ions like $\mathrm{K}^{+}$or $\mathrm{Cl}^{-}$to balance the solution electrically. In this case set $\operatorname{IOPT}(2)=2$, and use the keyword NEUTRAL and associated input to specify $\mathrm{K}$ and $\mathrm{Cl}$. The amount of $\mathrm{C} 1$ or $\mathrm{K}$ added will be listed in the output. One final alternative is to attribute the charge error to the most suspect analysis, e.g. carbon or sodium, or to a constituent known to be present for which one has no analytical data. Again, set IOPT(2) $=2$ and use the NEUTRAL input. Lack of charge balance is a meaningful clue to the errors in analyses and a large error probably makes a solution unsuitable for reaction simulation. By using the various options of the program, one can investigate the significance of analytical errors and their effects on reaction simulations. (Detailed test problems and examples for using PHREEQE are given in the section Test Problems.)

In the following description of the card input, the Fortran format for each card is given. Any Fortran manual will provide a complete explanation of the symbols used in format statements. Briefly, A indicates an alphanumeric character field, I an integer field, F floating point, $E$ single precision exponential, $D$ double precision exponential, and $X$ indicates spaces. The first number following A, I, D, E, or F defines the length of the field, or the number of columns on the card reserved for the field. All integers must be right justified in their fields. All exponential fields, when including an exponent, must be right justified. For floating point and exponential fields, it is suggested that the decimal point always be included. A number preceding a letter is the repeat counter and indicates the number of times the field occurs consecutively on the card. Similarly a number directly preceding a parenthesis indicates the number of times the formats contained within the parentheses are repeated as a group. Any blanks in I, F, E, or D fields are considered to be zeros. 
A. Title and option cards.

1. TITLE CARD TITLE

FORMAT (20A4)

Eighty characters of titles or comments.

2. OPTION CARD ( IOPT( $I), I=1,9$ ), NSTEPS, NCOMPS, VO

FORMAT ( $9 \mathrm{I} 1,1 \mathrm{X}, 2 \mathrm{I} 2,6 \mathrm{X}, \mathrm{F} 10.5$ )

$\operatorname{IOPT}(1)=0$, No print of thermodynamic data or coefficients of aqueous species.

$=1$, Print the aqueous model data (which are stored on disk) once during the entire computer run.

IOPT(2) $=0$, Initial solutions are not to be charge balanced. Reaction solutions maintain the initial charge imbalance.

$=1, \mathrm{pH}$ is adjusted in initial solution(s) to obtain charge balance.

$=2$, The total concentration of one of the elements (except $\mathrm{H}$ or 0 ) is adjusted to obtain electrical balance. NEUTRAL input is required.

$\operatorname{IOPT}(3)=0$, No reactions are modeled. Only the initial solutions are solved.

$=1$, Solution 1 is mixed (a hypothetical constant volume process) with solution 2 in specified reaction steps. STEPS input and a value for NSTEPS are required. MINERALS input may be included.

$=2$, Solution 1 is titrated with solution 2 in specified reaction steps. STEPS input, a value for NSTEPS, and a value for $V 0$ are required. MINERALS input may be included.

$=3$, A stoichiometric reaction is added in specified reaction steps. $\overline{\text { REACTION }}$ input, STEPS input, a value for NSTEPS, and a value for NCOMPS are required. MINERALS input may be included.

$=4, \mathrm{~A}$ net stoichiometric reaction is added in NSTEPS equal increments. REACTION input, STEPS input, 
a value for NSTEPS, and a value for NCOMPS are required. MINERALS input may be included. Only one value for the total reaction is read in STEPS.

$=5$, Solution number 1 is equilibrated with mineral phases only. No other reaction is performed. MINERALS input is required.

$=6$, A reaction is added to solution 1 until equilibrium is attained with the first phase in MINERALS input (equilibrium with other MINERALS phases is maintained throughout the reaction). REACTION input, a value for NCOMPS, and MINERALS input are required. No STEPS input is required. Note: there should be a common element in the reaction and the first phase in MINERALS input.

$\operatorname{IOPT}(4)=0$, The temperature of the reaction solution is (a) the same as the initial solution if adding a reaction, or (b) calculated linearly from the end members if mixing or titrating. No TEMP input required.

$=1$, The temperature is constant during the reaction steps and differs from that of the initial solution(s). One value is read in the TEMP input.

$=2$, The temperature is varied from $T_{o}$ to $T_{f}$ in NSTEPS equal increments during the reaction steps. A value for NSTEPS and two values of temperature, $T_{o}$ and $T_{f}$, (in order) are required in the TEMP input, where $\mathrm{T}_{\mathrm{O}}$ is the initial temperature and $\mathrm{T}_{\mathrm{f}}$ is the final temperature.

$=3$, The temperature of each reaction step is specified in TEMP input, in order. NSTEPS values are read.

$\operatorname{IOPT}(5)=0$, The pe from the initial solution is held constant during all the reaction steps for the simulation.

$=1$, The pe of the reaction solution is determined by the reaction. 
$\operatorname{IOPT}(6)=0$, Activity coefficients are calculated as follows:

a. the WATEQ Debye-Hückel formula is used for all species with GFLAG $=1$ (see SPECIES input below),

b. the Davies formula is used for all species with no ion size parameter ( $\mathrm{DHA}=0$, see SPECIES input),

c. the extended Debye-Hückel formula is used for all species with an ion size parameter ( DHA 0 ).

$=1$, Activity coefficients are calculated as follows:

a. the WATEQ Debye-Hücke1 formula is used for all species with GFLAG $=1$.

b. the Davies formula is used for all other species.

$\operatorname{IOPT}(7)=0$, Do not save the aqueous phase composition at the end of a reaction for additional simulations.

$=1$, Save the final reaction solution in solution number 1 .

$=2$, Save the final reaction solution in solution number 2 .

$\operatorname{IOPT}(8)=0$, The debugging print routine is not called.

$=1$, A long printout is output at each iteration in each problem. This print is to be used only if there are convergence problems with the program. (See Subroutine PBUG.)

$\operatorname{IOPT}(9)=0$, No printout of each array to be solved.

$=1$, A long printout occurs of the entire array to be solved at each iteration. This print is used only if there are convergence problems. (See Subroutine SLNQ.)

NSTEPS The number of reaction steps. A value is required if $\operatorname{IOPT}(3)=1,2,3$, or 4 , or if $\operatorname{IOPT}(4)=2$ or 3 . (Right justified.) 
NCOMPS The number of constituents in a net stoichiometric reaction. A constituent may be any element with an index number between 4 and 30 inclusive. No aqueous species with index numbers greater than 30 may be included as reaction constituents except $\mathrm{H}_{2}$ and $\mathrm{O}_{2}$. Any constituent with an index number greater than 30 is assumed to be either $\mathrm{H}_{2}$ or $\mathrm{O}_{2}$ and has the effect of raising or lowering the redox state of the solution depending on the assigned valence (THMEAN). A value for NCOMPS is required if $\operatorname{IOPT}(3)=3,4$, or 6 . (Right justified.)

v0

The initial volume of solution number 1 when modeling a titration. The unit of V0 must be the same as that of XSTEP (see STEPS input below) if $\operatorname{IOPT}(3)=2$. Otherwise, $v 0$ is not required.

B. Keyword data blocks. Blocks are preceded by a keyword card. The keywords are numbered and underlined in the following text. Each keyword must begin in the first column of the card. The appropriate cards, which are lettered in the text, must follow in order directly after the keyword.

\section{ELEMENTS FORMAT (A8) \\ This input defines the names and indices of all elements in the aqueous model data base. One card $1 . \mathrm{a}$ is read for each element. The index numbers of the elements do not need to be consec- utive or sequential. This input block must be terminated with one blank card. Generally these data will be part of the aqueous model stored on disk and read by the program at the beginning of each run. Only changes to the data base need to be in the input card deck.}

1.a. TNAME, NELT, TGFW

FORMAT (A8, 2X, I2, 3X, F10.0)

TNAME Alphanumeric name of element.

NELT Index number assigned to the element. Number must be between 4 and 30 , inclusive. (Right justified.) 
TGFW Gram formula weight of the species used to report the analytical data. If solution data is to include alkalinity, TGFW for the element carbon must be the equivalent weight of the reported alkalinity species. TGFW is not used if the concentrations are entered as molality (IUNITS $=0$ in SOLUTION input card $3 . b$ ).

1.b. Blank card.

\section{SPECIES}

FORMAT (A8)

This input defines the names, index numbers and composition of all aqueous species in the aqueous model data base. Cards 2.a, 2.b, 2.c, and 2.d are read for each species. The index numbers for the species do not need to be sequential or consecutive. This input block must be terminated with one blank card. To eliminate a species (already in the PHREEQE data array) from the aqueous model only card 2.a followed by a blank card 2.b must be entered. More species changes could then follow or a second blank card would terminate this input block. All species must have association reactions which contain only master species (species numbers less than or equal to 30 ; see discussion in section, Equilibrium Equations). Reactions containing non-master species must be converted to master species reactions and the appropriate association constants must be calculated before they can be entered into the program. These data are generally stored in the disk file which is read by the program at the beginning of each run and retained for the entire run. Only changes and additions would appear in the input card deck.

2.a. I

FORMAT (I3)

I

The index number assigned to the aqueous species. Numbers 4 through 30 are reserved for master species. 250 is the maximum index number for an aqueous species. (Right justified.)

2.b. SNAME, NSP, KFLAG, GFLAG, ZSP; THSP, DHA, ADHSP(1), ADHSP (2), ALKSP

FORMAT (A8, 2X, I3 , 2I1,6F10.3)

Three different formulations are available for the activity coefficient expression. 
Three different formulations are available for the activity coefficient expression.

i) Extended Debye-Hücke1,

$$
\log \gamma_{i}=\frac{-A z_{i}^{2} \sqrt{I}}{1+B a_{i}^{o} \sqrt{I}}
$$

ii) WATEQ Debye-Hücke1

$$
\log \gamma_{i}=\frac{-A z_{i}^{2} \sqrt{I}}{1+B a_{i} \sqrt{I}}+b_{i} I
$$

iii) Davies

$$
\text { Log } \gamma_{i}=-A z_{i}^{2}\left(\frac{\sqrt{I}}{1+\sqrt{I}}-0.3 I\right) \text {, }
$$

where $A$ and $B$ in all three equations are constants depending on the dielectric constant of the solvent and the temperature (Robinson and Stokes, 1970).

SNAME Alphanumeric species name.

NSP The total number of master species in the association reaction that forms this species; do not count the species itself unless the species is a master species. (Right justified.)

KFLAG $=0$, The Van't Hoff expression is used to calculate temperature dependence of the association constant for this species.

$=1$, An analytical expression is used to calculate temperature dependence of the association constant. Values for ASP are required on card 2.c.

GFLAG $=0$, The extended Debye-Hücke1 or Davies expression (according to IOPT(6)) is used to calculate the activity coefficient for this species if DHA $>0$ (see below). If DHA $=0$ and GFLAG $=0$, the Davies equation is always used regardless of $\operatorname{IOPT}(6)$. 
$=1$, The WATEQ Debye-Hückel expression is used to calculate the activity coefficient of this species regardless of the value of IOPT(6).

ZSP The charge on this aqueous species.

THSP The sum of the OPV's of the redox species in this species. (e.g. $\mathrm{FeSO}_{4}^{\circ}$ has a $\operatorname{THSP}=2+6=8$.)

DHA The extended Debye-Hückel $a_{i}^{0}$ term. If this parameter is zero and GFLAG $=0$ then the Davies equation is used to calculate the activity coefficient for this species.

$\operatorname{ADHSP}(1)$ The $a_{i}$ term for the WATEQ Debye-Hückel expression.

ADHSP(2) The $b_{i}$ term for the WATEQ Debye-Hũckel expression.

ALKSP The alkalinity assigned to this aqueous species. (See discussion in Numerical Methods section.)

\section{2.c. LKTOSP, $\operatorname{DHSP},(\operatorname{ASP}(I), I=1,5)$}

FORMAT (2F 10.3,5E12.5)

Constants used to evaluate the association constant as a function of temperature. The analytical expression has the form:

$$
\log (\mathrm{K})=\mathrm{A}_{1}+\mathrm{A}_{2} \mathrm{~T}+\mathrm{A}_{3} / \mathrm{T}+\mathrm{A}_{4} \mathrm{~T}^{2}+\mathrm{A}_{5} / \mathrm{T}^{2}
$$

where $\mathrm{T}$ is expressed in ${ }^{\circ} \mathrm{K}$.

LKTOSP $\log _{10}$ of the mass action association constant at $25^{\circ} \mathrm{C}$ (used in Van't Hoff equation).

DHSP Standard enthalpy of the association reaction at $25^{\circ} \mathrm{C}\left(\Delta_{\mathrm{r}}^{\mathrm{O}}\right.$, in $\left.\mathrm{kcal} / \mathrm{mole}\right)$; used in the Van't Hof $\mathrm{f}$ calculation of the temperature dependence of the association reaction. Required if KFLAG $=0$. (A zero or blank will result in no temperature variation in the association constant.)

ASP(1) Constant term in the analytical expression for the association constant, $\left(A_{1}\right)$. The array ASP is used if KFLAG $=1$. 
ASP(2) Coefficient of $\mathrm{T}^{\circ} \mathrm{K}$ in analytic expression, $\left(\mathrm{A}_{2}\right)$.

$\operatorname{ASP}(3)$ Coefficient of $1 / \mathrm{T}$ in analytic expression, $\left(A_{3}\right)$.

ASP(4) Coefficient of $\mathrm{T}^{2}$ in analytic expression, $\left(\mathrm{A}_{4}\right)$.

$\operatorname{ASP}(5)$ Coefficient of $1 / \mathrm{T}^{2}$ in analytic expression, $\left(A_{5}\right)$.

2.d. (LSP (I), $\operatorname{CSP}(I), I=1, N S P)$

FORMAT 6(I3,F7.3)

List of master species numbers and their coefficients in the mass action association reaction. NSP pairs of values, LSP and CSP, are read. One and only one of these cards is required for each species.

LSP(I) Index number of master species. (Right justified.)

CSP(I) Stoichiometric coefficient of master species in this aqueous species.

For example, using the data base in Attachment A for master species, the reactions below define variables as shown:

$$
\mathrm{Ca}^{2+}+\mathrm{H}^{+}+\mathrm{CO}_{3}^{2-}=\mathrm{CaHCO}_{3}^{+} \quad \text { (species } 77 \text { ) }
$$

NSP $=3$

$\operatorname{LSP}(1)=4, \operatorname{CSP}(1)=1.0 ; \operatorname{LSP}(2)=1, \operatorname{CSP}(2)=1.0 ;$

$\operatorname{LSP}(3)=15, \operatorname{CSP}(3)=1.0$

or,

$$
\mathrm{SO}_{4}^{2-}+8 \mathrm{H}^{+}+8 e^{-}=\mathrm{s}^{2-}+4 \mathrm{H}_{2} \mathrm{O} \quad(\text { species } 41)
$$

$$
\mathrm{SO}_{4}^{2-}+8 \mathrm{H}^{+}+8 \mathrm{e}^{-}-4 \mathrm{H}_{2} \mathrm{O}=\mathrm{S}^{2-}
$$

$$
\begin{aligned}
& \operatorname{NSP}=4 \\
& \operatorname{LSP}(1)=16, \operatorname{CSP}(1)=1.0 ; \operatorname{LSP}(2)=1, \operatorname{CSP}(2)=8.0 ; \\
& \operatorname{LSP}(3)=2, \operatorname{CSP}(3)=8.0 ; \operatorname{LSP}(4)=3, \operatorname{CSP}(4)=-4.0
\end{aligned}
$$

2.e. Blank card. 


\section{SOLUTION $\mathrm{n}$ FORMAT (A8, 1X, I1)}

This input is used to define a starting solution. $n$ can be either 1 or 2 and indicates the solution number of the data following. Cards 3.a and 3.b are required. Card 3.c is not included if NTOTS $=0$. There must be as many card 3.c's as necessary to read NTOTS total concentrations.

3.a. HEAD

FORMAT ( 20A4)

Title or comments about the solution.

HEAD Alphanumeric heading.

3.b. NTOTS, IALK, IUNITS, PH, PE, TEMP, SDENS

FORMAT (I2, I3, I2, 3X, 4F 10.3)

NTOTS The number of total concentrations to be read from card 3.c input. For example, if the starting solution is a $\mathrm{MgCl}_{2}-\mathrm{NaHCO}_{3}$ solution, NTOTS $=4$ (for $\mathrm{Mg}, \mathrm{Cl}, \mathrm{Na}$, and $\mathrm{C}$ ). (Right justified.)

IALK Flag which indicates whether total carbon or total alkalinity is to be input. (Right justified.)

$=0$ indicates the total concentration of carbon (not alkalinity) is input in the units specified by IUNITS (see below).

$=\mathrm{n} \quad 4 \leq \mathrm{n} \leq 30$, where $\mathrm{n}$ is the index number for the element carbon, (in our data base $n=15$ ) indicates total alkalinity is being entered. If alkalinity is used $(n>0)$, then IOPT(2) can not be equal to 1 . It is theoretically impossible to use $\mathrm{pH}$ to achieve electrical neutrality if the alkalinity is fixed. ELEMENTS input may be required. The units of alkalinity are specified by IUNITS (below) and if IUNITS $>0$, the gram formula weight (GFW) of the element carbon is critically important. The GFW in the case of alkalinity must be the gram equivalent weight (grams/ equivalent) of the chemical species in which the alkalinity is reported. The following is a list of species commonly used for reporting alkalinity and their corresponding equivalent weights : 


$$
\begin{array}{ll}
\mathrm{CaCO}_{3} & 50.0446 \mathrm{~g} / \mathrm{eq} \\
\mathrm{HCO}_{3}^{-} & 61.0171 \mathrm{~g} / \mathrm{eq} \\
\mathrm{CO}_{3}^{2-} & 30.0046 \mathrm{~g} / \mathrm{eq} .
\end{array}
$$

In our data base 44.010 is the GFW of carbon which is suitable for entering carbon as total $\mathrm{CO}_{2}$. This GFW must be changed via ELEMENTS input if alkalinity is to be entered as $\mathrm{mg} / 1$ or $\mathrm{ppm}$ (IUNITS $=2$ or 3 ). If IUNITS $=0$ alkalinity must be input as eq $/ \mathrm{kg} \mathrm{H}_{2} \mathrm{O}$ and in this case the GFW need not be changed because no conversion of units is necessary. For a discussion of the contribution of the different aqueous species to the total alkalinity see the Numerical Methods section.

IUNITS Flag describing units of input concentrations (right justified). The program makes all of its calculations in terms of molality and any other allowed concentration units (mmoles/1, $\mathrm{mg} / 1$, or $\mathrm{ppm}$ ) must be converted to molality before the calculations may begin. To make the conversions it is necessary to know the gram formula weight (GFW), in $\mathrm{g} / \mathrm{mole}$, of the chemical formula in which elemental analyses are reported. The GFW is an input parameter under ELEMENTS input and must be in agreement with the analytical units for each solution data set. (If the units are molality, no conversion is necessary and the GFW's are not used.) Consider silicon as an example: Si is commonly reported as ppm of $\mathrm{SiO}_{2}$ but may also be given as ppm $\mathrm{H}_{4} \mathrm{SiO}_{4}$. To convert ppm $\mathrm{SiO}_{2}$ to moles $\mathrm{Si} / \mathrm{kg} \mathrm{H} \mathrm{H}_{2} \mathrm{O}$ the GFW for silicon in the ELEMENTS data must be 60.0843 . For ppm $\mathrm{H}_{4} \mathrm{SiO}_{4}$ the GFW must be 96.1147 . If the units of the water analysis do not correspond to the GFW for any element, the GFW must be changed using ELEMENTS input or the data must be converted by hand before input into the program. Values of GFW used in the preliminary PHREEQE data base are given in Table 1. Note: All elements must have the same units. It is not possible to enter $\overline{\mathrm{mg} / 1}$ of one element and molality of another. 
$=0$ Concentration of elements entered as molality of each element, or for alkalinity, equivalents $/ \mathrm{kg} \mathrm{H} \mathrm{H}_{2}$.

$=1$ Concentration of elements entered as mmoles $/ 1$ of each element, or for alkalinity, meq/1.

$=2$ Concentration of elements entered as $\mathrm{mg} / 1$ of the species which has a gram formula weight given in ELEMENTS input. (ELEMENTS input may be required.) For alkalinity see discussion under IALK above.

$=3$ Concentration of elements entered as ppm of the species which has a gram formula weight given in ELEMENTS input. (ELEMENTS input may be required.) For alkalinity see discussion under IALK above.

$\mathrm{PH} \quad$ The $\mathrm{pH}$ of the solution (the approximate $\mathrm{pH}$ if $\operatorname{IOPT}(2)=1)$. Required for all solutions.

PE The pe of the solution. Required for all solutions.

TEMP The temperature of the solution in ${ }^{\circ} \mathrm{Celsius.}$

SDENS The density of the solution. Required if concentrations are input as mmoles/1, $\mathrm{mg} / 1$, or ppm. If SDENS is omitted, 1.0 is assumed.

3.c. (LT(I), DTOT(I), $I=1$, NTOTS)

FORMAT 5(I4,D11.3)

Total concentrations of elements. Five values of LT and DTOT are read on each card. The card may be repeated in order to enter all the elements desired. All data must appear consecutively in the fields, no blanks or zeros are allowed as values for LT. Omit this card if NTOTS is zero, the case of pure water.

LT

Index number of the element. (Right justified.)

DTOT

Total concentration of the element in molality, mmoles $/ 1$, $\mathrm{mg} / 1$, or $\mathrm{ppm}$ according to IUNITS. 


\section{MINERALS FORMAT (A8)}

This input defines the phases which will be maintained at equilibrium with each of the reaction solutions. Cards $4 . a$ and $4 . b$ are required for each mineral. Card 4.c is optional for each mineral depending on the value of MFLAG. Unlike SPECIES, MINERALS may be defined in terms of any aqueous species, not just the master species. The input expression for the equilibrium constant must correspond with the input mass action coefficients. Mineral reactions are written as dissociation reactions. MINERALS input must be terminated with a blank card.

4.a. MNAME, NMINO, THMIN, LKTOM, DHMIN, MFLAG, SIMIN FORMAT (A8, 2X, I2 , 3X, 3F 10.2, 5X, I1 , 9X, F10.3)

Constant parameters for this mineral.

MNAME Alphanumeric name of mineral.

NMINO Number of different species in the mineral dissociation reaction (including $\mathrm{H}^{+}, \mathrm{e}^{-}$, and $\mathrm{H}_{2} \mathrm{O}$ ). NMIN0 must be less than or equal to 10 . (Right justified.)

THMIN The sum of the OPV's of the species in the mineral dissociation reaction.

For example,

$$
\mathrm{FeS}_{2}=\mathrm{Fe}^{2+}+2 \mathrm{~S}^{2-}-2 \mathrm{e}^{-}
$$

THMIN $_{\text {Pyrite }}=1(+2)+2(-2)-2(-1)=0$

$$
\begin{aligned}
\mathrm{Fe}(\mathrm{OH})_{3} & =\mathrm{Fe}^{3+}+3 \mathrm{OH}^{-} \\
\operatorname{THMIN}_{\mathrm{Fe}(\mathrm{OH})_{3}} & =1(+3)+3(0)=+3
\end{aligned}
$$

$$
\begin{aligned}
& \mathrm{CaCO}_{3}=\mathrm{Ca}^{2+}+\mathrm{CO}_{3}^{2-} \\
& \operatorname{THMIN}_{\mathrm{CaCO}_{3}}=1(0)+1(+4)=+4
\end{aligned}
$$

LKTOM Log of the equilibrium constant at $25^{\circ} \mathrm{C}$ for the reaction. 


$\begin{aligned} \text { DHMIN } \quad & \Delta \mathrm{H}_{\mathrm{r}} \text { (kcal/mole) for the Van't Hoff expression. } \\ \text { MFLAG }= & 0 \text {, The Van't Hoff expression is used to calcu- } \\ & \text { late the temperature dependence of the equil- } \\ & \text { ibrium constant. } \\ = & 1 \text {, The analytical expression is used to calcu- } \\ & \text { late the temperature dependence of the equil- } \\ & \text { ibrium constant. Card } 4 . c \text { is required. } \\ & \text { Saturation index (log(Ion Activity Product/K } \mathrm{K}_{\mathrm{sp}} \text { )) } \\ & \text { desired in the final solution. SIMIN } 0.0 \\ & \text { would produce equilibrium with the mineral } \\ & \text { while } 1.0 \text { would produce a solution } 10 \text { times } \\ & \text { supersaturated (SI } 1.0 \text { ). This variable is } \\ & \text { useful in specifying the partial pressure of } \\ & \text { a gas. The Henry's law constant for the gas } \\ & \text { would be entered using the Van't Hoff constant } \\ & \text { (LKTOM) or analytical expression (AMIN) and the } \\ & \text { log of the partial pressure would be entered for } \\ & \text { for sIMIN. }\end{aligned}$

4.b. ( $\operatorname{LMIN}(I), \operatorname{CMIN}(I), I=1, \operatorname{NMIN0})$

FORMAT 5(I4,F11.3)

List of species index numbers and stoichiometric coefficients in the dissociation reaction for this mineral. NMINO pairs of numbers, LMIN and CMIN, are read. The maximum value of NMINO is 10. If NMINO is greater than 5 , a second card $4 . b$ is required.

LMIN(I) Index number of species (not necessarily master species) in the dissociation reaction for this mineral. (Right justified.)

CMIN(I) Stoichiometric coefficient of species in dissociation reaction.

For example, using the data for aqueous species index numbers in At tachment $A$,

$$
\text { i. } \begin{aligned}
& \mathrm{CaCO}_{3}=\mathrm{Ca}^{2+}+\mathrm{CO}_{3}^{2-} \\
& \operatorname{NMINO}=2 \\
& \operatorname{LMIN}(1)=4, \operatorname{CMIN}(1)=1.0 ; \\
& \operatorname{LMIN}(2)=15, \operatorname{CMIN}(2)=1.0 .
\end{aligned}
$$


ii.

$$
\begin{aligned}
& \mathrm{FeS}_{2}+2 \mathrm{e}^{-}=\mathrm{Fe}^{2+}+2 \mathrm{~S}^{2-} \\
& \text { or, } \mathrm{FeS}_{2}=\mathrm{Fe}^{2+}+2 \mathrm{~s}^{2-}-2 \mathrm{e}^{-} \\
& \text {NMINO }=3 \\
& \operatorname{LMIN}(1)=8, \operatorname{CMIN}(1)=1.0 ; \\
& \operatorname{LMIN}(2)=41, \operatorname{CMIN}(2)=2.0 \text {; } \\
& \operatorname{LMIN}(3)=2, \operatorname{CMIN}(3)=-2.0 \text {. } \\
& \mathrm{CaSO}_{4} \cdot 2 \mathrm{H}_{2} \mathrm{O}=\mathrm{Ca}^{2+}+\mathrm{SO}_{4}^{2-}+2 \mathrm{H}_{2} \mathrm{O} \\
& \text { NMINO }=3 \\
& \operatorname{LMIN}(1)=4, \operatorname{CMIN}(1)=1.0 \text {; } \\
& \operatorname{LMIN}(2)=16, \operatorname{CMIN}(2)=1.0 ; \\
& \operatorname{LMIN}(3)=3, \operatorname{CMIN}(3)=2.0 \text {. }
\end{aligned}
$$

iii.

iv.

$$
\mathrm{Ca}^{2+}-\mathrm{Na}^{+} \text {ion exchange. (Assumes com- }
$$
position of exchanger does not change.)

$$
\mathrm{Na}_{2}(\mathrm{ex})+\mathrm{Ca}^{2+}=\mathrm{Ca}(\mathrm{ex})+2 \mathrm{Na}^{+}
$$

or

$$
\mathrm{Na}_{2}(\mathrm{ex})-\mathrm{Ca}(\mathrm{ex})=2 \mathrm{Na}^{+}-\mathrm{Ca}^{2+}
$$

NMINO $=2$

$\operatorname{LMIN}(1)=6, \operatorname{CMIN}(1)=2.0$;

$\operatorname{LMIN}(2)=4, \operatorname{CMIN}(2)=-1.0$.

LKTOM $=\frac{\mathrm{a}_{\mathrm{Na}}^{2}}{\mathrm{a}_{\mathrm{Ca}}{ }^{2+}}$ at exchange equilibrium.

v.

Fix $\mathrm{CO}_{2}$ partial pressure.

or

$$
\mathrm{CO}_{2} \text { (gas) }+\mathrm{H}_{2} \mathrm{O}=\mathrm{H}_{2} \mathrm{CO}_{3}(\mathrm{aq})
$$

$$
\mathrm{CO}_{2} \text { (gas) }=\mathrm{H}_{2} \mathrm{CO}_{3}(\mathrm{aq})-\mathrm{H}_{2} \mathrm{O}
$$

$$
\begin{aligned}
& \text { NMINO }=2 \\
& \operatorname{LMIN}(1)=35, \operatorname{CMIN}(1)=1.0 ; \\
& \operatorname{LMIN}(2)=3, \operatorname{CMIN}(2)=-1.0, \\
& \operatorname{LKTOM}=\text { Henry's 1aw constant for } \mathrm{CO}_{2}, \\
& \text { SIMIN }=\log \mathrm{P}_{\mathrm{CO}_{2}} \text { desired. }
\end{aligned}
$$


4.c. $\operatorname{AMIN}(I), I=1,5$

FORMAT (5E12.5)

Equilibrium constant expression of the form:

$$
\log (\mathrm{K})=\mathrm{A}_{1}+\mathrm{A}_{2} \mathrm{~T}+\mathrm{A}_{3} / \mathrm{T}+\mathrm{A}_{4} \mathrm{~T}^{2}+\mathrm{A}_{5} / \mathrm{T}^{2},
$$

for the mineral dissociation reaction where $\mathrm{T}$ is ${ }^{\circ} \mathrm{K}$. This card is used only if MFLAG $=1$.

$$
\begin{aligned}
& \text { AMIN(1) Constant coefficient of analytical } \\
& \text { expression, ( } A_{1} \text { above). } \\
& \text { AMIN(2) Coefficient of } \mathrm{T}^{\mathrm{O}} \mathrm{K} \text { in analytical } \\
& \text { expression, }\left(\mathrm{A}_{2}\right) \text {. } \\
& \text { AMIN(3) Coefficient of } 1 / T \text { in analytical } \\
& \text { expression, }\left(\mathrm{A}_{3}\right)_{2} \\
& \operatorname{AMIN}(4) \text { Coefficient of } \mathrm{T}^{2} \text { in analytical } \\
& \text { expression, }\left(\mathrm{A}_{4}\right) \text {. } \\
& \operatorname{AMIN}(5) \text { Coefficient of } 1 / \mathrm{T}^{2} \text { in analytical } \\
& \text { expression, }\left(\mathrm{A}_{5}\right) \text {. }
\end{aligned}
$$

4.d. Blank card.

\section{LOOK MIN}

FORMAT (A8)

The purpose of this input is simply to provide information on the saturation state of the aqueous phase with respect to desired minerals. The minerals in this block of input do not affect the calculations of the initial solution or any of the reaction solutions. This input is never mandatory. The Ion Activity Product (IAP) and saturation index $(\mathrm{SI}=\log (\mathrm{IAP} / \mathrm{K}))$ of each of these minerals is printed in the output following each solution description. Only the minerals which contain elements present in the solution are printed. The input following this card is identical to the input for MINERALS (see above). This input must be terminated with a blank card.

The list of "look minerals" is maintained for the duration of the run and any new "look mineral" is simply added to the 1ist. If a "look mineral" is added that has the identical 8 letter name as another mineral in the 1 ist, the new mineral replaces the old mineral. The word DELETE as a mineral name will eliminate all of the minerals in the list and new minerals may be added. Only thirty nine "look minerals" are allowed. LOOK MIN 
input is generally placed in the disk file which is read at the beginning of each run. The input card deck need only contain additions and changes to that permanent list.

6. TEMP FORMAT (A8)

This input varies the temperature during the reaction steps. It is required input if IOPT(4) is greater than 0 . Only one card $6 . a$ is necessary unless $\operatorname{IOPT}(4)=3$. In that case as many cards as necessary to input NSTEPS values are required.

6.a. XTEMP

FORMAT ( 8 F 10.1$)$

XTEMP Temperature in degrees Celsius.

If $\operatorname{IOPT}(4)=1$, one value of XTEMP is coded.

If $\operatorname{IOPT}(4)=2$, two values of XTEMP are coded, $\mathrm{T}_{\mathrm{o}}$ and $\mathrm{T}_{\mathrm{f}}$ (in order).

If $\operatorname{IOPT}(4)=3$, NSTEPS values of XTEMP are coded (no blank fields permitted).

7. STEPS FORMAT (A8)

This input defines the steps of the reaction process. The input has a different meaning depending on the value of IOPT(3) (option card).

$\operatorname{IOPT}(3)=1, \operatorname{XSTEP}$ is the fraction of solution 1 to be mixed with solution 2 . NSTEPS values are read.

$\operatorname{IOPT}(3)=2$, XSTEP is the volume of solution 2 to be titrated into solution 1. XSTEP must have the same units as vo (option card). NSTEPS values are read.

$\operatorname{IOPT}(3)=3$, XSTEP is the moles of reaction to be added to solution 1 . NSTEP values are read.

$\operatorname{IOPT}(3)=4$, Only one value of XSTEP is read. XSTEP is the total number of moles of reaction to be added in NSTEPS steps. NSTEPS reaction solutions 
will be calculated. The $\mathrm{I}^{\mathrm{th}}$ solution will have I'XSTEP/NSTEPS moles of reaction added to solution 1 .

7.a. XSTEP

FORMAT ( $8 \mathrm{~F} 10.3)$

XSTEP Reaction increments as defined above.

\section{REACTION FORMAT (A8)}

This input describes the stoichiometry and valence of the elements to be added as a reaction. STEPS input (see above) defines the total number of moles of this reaction to be added. The REACTION process changes the total aqueous concentration of an element by the stoichiometric coefficient (CREAC) times the total moles of reaction (XSTEP). (However, the final total concentration in the reaction solution may also be altered by mass transfer to achieve equilibrium with minerals specified in MINERALS input.) It is necessary to consider the charge balance of the reaction which is added. A charge imbalance by an input error or by intent is equivalent to adding acid or base. If the reaction is a simulation from a known solution to another known solution it is possible to add an inert electrical charge equal to the difference in the charge imbalance between the two solutions. Set $\operatorname{LREAC}(I)=0, \operatorname{CREAC}(I)=$ charge imbalance (equivalents $/ \mathrm{kgH}_{2} \mathrm{O}$ ) and $\operatorname{THMEAN}(\mathrm{I})=0.0$. This will eliminate implicit addition of acid or base. Card 8.a is repeated as often as necessary to read NCOMPS (option card) reaction constituents.

8.a. (LREAC(I), CREAC(I), THMEAN(I), I = 1, NCOMPS) FORMAT 4(I4, 2F8.3)

This input defines a net stoichiometric reaction. Four triples of numbers are read on each card. Enough cards must be included to read NCOMPS triples of numbers.

LREAC(I) Index number of element for the reaction. LREAC must be between 4 and 30 inclusive. If LREAC is greater than 30 the program considers this constituent to be $\mathrm{H}_{2}$ or $\mathrm{O}_{2}$ and only uses CREAC and THMEAN (below) to change the oxidation state of the reaction solution. (Right justified.) 
CREAC(I) Stoichiometric coefficient of the element in the reaction.

THMEAN(I) The OPV of the element in the reaction (e.g. carbon as carbonate: THMEAN $=+4$; carbon as methane: THMEAN $=-4$; ferrous iron: +2 ; and ferric iron: +3 ). An element may be included more than once in a reaction to accomodate different valence states of the element.

The variables which affect a reaction simulation are IOPT(3), NSTEPS, and NCOMPS from the option card, REACTION input and STEPS input. The following examples use the species index numbers from Attachment A.

i. Gypsum is added to the initial solution in 5 equal increments of 0.005 moles, to a total of .025 moles. Calcite equilibrium is maintained in each of the five steps.

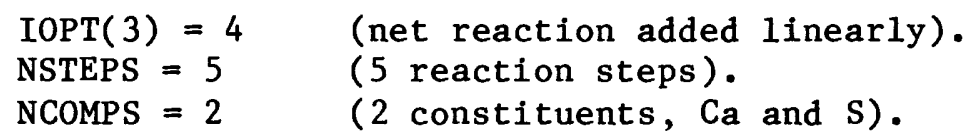

The total calcium at the completion of the first reaction step is given by:

$$
\mathrm{Ca}_{\text {tot }}=\mathrm{Ca}_{\text {tot(initial) }}+.005+\mathrm{MIN}_{\text {calcite }} \text {. }
$$

ii. Suppose mass balance between two solutions shows calcite, gypsum, and dolomite dissolving $(+)$ and precipitating (-) in proportions of $-1: 1.5: 1$. The net reaction is written:

$$
\begin{aligned}
& \text { - } 1 \mathrm{Ca} \quad-1 \mathrm{C} \quad \text { Calcite } \\
& +1.5 \mathrm{Ca}+1.5 \mathrm{~S} \quad \text { Gypsum } \\
& \begin{aligned}
+1 \mathrm{Ca}+1 \mathrm{Mg}+2 \mathrm{C} & \text { Dolomite } \\
\hline 1.5 \mathrm{Ca}+1 \mathrm{Mg}+1 \mathrm{C}+1.5 \mathrm{~S} & \text { NET }
\end{aligned}
\end{aligned}
$$

Three points along this possible path are modeled by (arbitrarily) adding $10^{-4}, 10^{-3}$, and $10^{-2}$ moles of the net reaction. 


$\begin{array}{llll}\text { IOPT }(3)=3 & & \text { (add net reaction in specified steps). } \\ \text { NSTEPS } & =3 & & \text { (number of steps). } \\ \text { NCOMPS } & =4 & & \text { (number of constituents in the reaction). } \\ \text { LREAC }(1)=4, & & \operatorname{CREAC}(1)=1.5, \operatorname{THMEAN}(1)=0.0(\mathrm{Ca}) ; \\ \text { LREAC (2) }=5, & & \operatorname{CREAC}(2)=1.0, \operatorname{THMEAN}(2)=0.0(\mathrm{Mg}) ; \\ \text { LREAC (3) }=15, & & \operatorname{CREAC}(3)=1.0, \operatorname{THMEAN}(3)=4.0(\mathrm{C}) ; \\ \operatorname{LREAC}(4)=16, & \operatorname{CREAC}(4)=1.5, \operatorname{THMEAN}(4)=6.0(\mathrm{~S}) \\ \operatorname{XSTEP}(1)=10^{-4}, & \operatorname{XSTEP}(2)=10^{-3}, \operatorname{XSTEP}(3)=10^{-2} .\end{array}$

(Reaction increments in moles, reaction is not cumulative.)

\section{NEUTRAL FORMAT (A8)}

This input defines the elements to be used to adjust the initial solution(s) to electrical neutrality. One element with a master species cation and one element with a master species anion are input. $\mathrm{H}^{+}$and $\mathrm{e}^{-}$are not valid entries. A master cation and anion are required in order to add one or the other element according to the charge imbalance. Species are not subtracted, eliminating the possibility of negative total concentrations. This input is required only if $\operatorname{IOPT}(2)=2$. (Note that this is not equivalent to adding or subtracting charge as discussed in REACTION; remember that IOPT(2) $=0$ will maintain an original charge imbalance during a simulation.)

9.a. LPOS, LNEG

FORMAT (2I5)

LPOS Index number of an element with a cation master species. (Right justified.)

LNEG Index number of an element with a anion master species. (Right justified.)

\section{SUMS FORMAT (A8)}

This input sums molalities of aqueous species which are then printed in the output of the run. These sums do not affect the calculations in any way and are never mandatory. These sums could, for example, be used to define an alternate sum of species for the alkalinity. The "sums" are defined by lists of species numbers, so that each time a sequence number for a species is listed, the sum is incremented by the molality of that species. If the species has, for example, two carbonate ions and the total carbonate is the sum which is desired then the species should be listed twice in that sum. Up to 10 dif- 
ferent sums may be defined. Each sum may have up to 50 species. Cards $10 . \mathrm{a}$ and $10 . \mathrm{b}$ are required for each sum. This input, after all sums have been defined, must be terminated with one blank card. As in LOOK MIN input the sums are kept for the duration of the run but it is possible to add or replace sums or delete the entire set in any single simulation. Any sum input in this data block will be added to the list of sums if the name (SUNAME) is different from all other sum names. A sum with the identical name will replace the sum already in the list. The word DELETE as a sum name will eliminate all the sums known to the computer.

10.a. SUNAME, NSUM

FORMAT $(\mathrm{A} 8,2 \mathrm{X}, \mathrm{I} 2)$

SUNAME Alphanumeric name to be printed to identify the sum.

NSUM The number of index numbers to be read on card(s) 10.b; NSUM 50. (Right justified.)

10.b. $\quad(\operatorname{LSUM}(I, J), J=1$, NSUM)

FORMAT (20I4)

List of species numbers to define the sum. Twenty index numbers are read on this card. The card may be repeated as many times as necessary to input NSUM index numbers.

LSUM Index numbers of species in sum. (Right justified.)

Note: repeat cards $10 . \mathrm{a}$ and $10 . \mathrm{b}$ for each sum.

10.c. Blank card. One blank card at the end of all sums is required to terminate this input.

11. END

FORMAT (A8)

This card terminates input operations for a single simulation. Initial solution(s) and reaction solution(s) are computed as directed by the preceeding input. Any computer run has at least one END card. 
Attachment B. - Example using PHRQINPT to construct input data set a priori. 
EXAMPLE 1

ENTER OUTPUT FILE NAME
EXAMPLE.1

ENTER REFERENCE FILE NAME: (HIT 〈CR> TO OMIT)

INPUT THE TITLE

ADD OXYGEN AT PYRITE-CALCITE-GOETHITE EQUILIBRIUM

ADD OXYGEN AT PYRITE-CALCITE-GOETHITE EQUILIBRIUM O.K.?

$\mathrm{Y}$

INPUT IOPT(1)

0

INPUT IOPT(2)

1

INPUT IOPT(3)

3

INPUT IOPT(4)

0

INPUT IOPT(5)

1

INPUT IOPT(6)

1

INPUT IOPT(7)

0

INPUT IOPT(8)

0

INPUT IOPT(9)

0

INPUT NSTEPS

5

INPUT NCOMPS

1

$013011000 \quad 51 \quad 0.0$

O.K.?

$\mathrm{Y}$ 


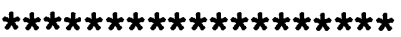

KEYWORD DATA BLOCKS

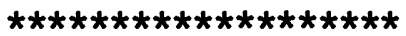

ENTER KEYWORD.

SOLUTION

SOLUTION

INPUT SOLUTION NUMBER

1

SOLUTION 1

O.K.?

$\mathrm{Y}$

INPUT HEAD

PURE WATER

PURE WATER

O.K.?

Y

INPUT NTOTS

0

INPUT PH

7

SOLUTION

PH

FORMAT (F10.3)
THE PH OF THE SOLUTION (THE APPROXIMATE PH IF $\operatorname{IOPT}(2)=1$ )

INPUT PH

7.

INPUT PE

4. 
INPUT TEMP

25.

$\begin{array}{ccccccc}0 & 0 & 0 & 7 . & 4 . & 25 . & 1.0 \\ \mathrm{Y} . \mathrm{K} . ? & & & & \end{array}$

$\star * * * * * * * * * * * * * * * * * *$

KEYWORD DATA BLOCKS

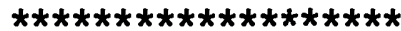

ENTER KEYWORD.

MINERALS

MINERALS

PRE-CONSTRUCTED MINERAL DATA ARE AVAILABLE. DO YOU WISH TO HAVE ANY OF THEM?

Y

\begin{tabular}{|c|c|c|c|c|}
\hline CALCITE & 2 ARAGONIT & 3 DOLOMITE & 4 SIDERITE & 5 RHODOCHR \\
\hline STRONTIT & 7 GYPSUM & 8 ANHYDRIT & 9 CELESTIT & 10 BARITE \\
\hline HYDROXAP & 12 VIVIANIT & 13 FLUORITE & 14 FEOHЗA & 15 HEMATITE \\
\hline PYRITE & 17 GOETHITE & 18 GIBBSITE & 19 CHALCEDY & 20 QUARTZ \\
\hline KAOLINIT & 22 SEPIOLIT & 23 FES PPT & 24 BIRNESIT & 25 MANGANIT \\
\hline SIL GEL & 27 SIL GLAS & 28 SEP PPT & 29 MACKINIT & 30 MUSCOVIT \\
\hline MICROCLN & $32 \mathrm{CO} 2 \mathrm{GAS}$ & 33 O2 GAS & $34 \mathrm{H} 2$ GAS & 35 N2 GAS \\
\hline H2S GAS & CH4 GAS & $38 \mathrm{NHB}$ GAS & & \\
\hline
\end{tabular}

ENTER THE INDEX NUMBER OF MINERAL. (TYPE 〈STOP> TO EXIT) 16

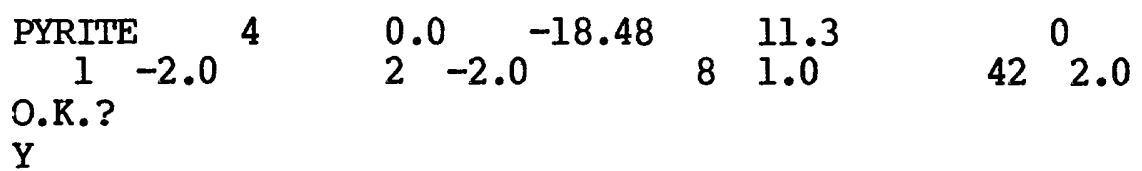

ENTER THE INDEX NUMBER OF MINERAL. (TYPE 〈STOP〉 TO EXIT) 17
GOETHITE
3
3.0
$0.486 \quad \begin{array}{ll}-14.48 \\ 1-3.0\end{array}$
0
115
O.K.? 
Y

ENIER THE INDEX NUMBER OF MINERAL. (TYPE 〈STOP> TO EXIT) 1

$\begin{array}{llllll}\text { CALCITE } & 2 & 4.0 & -8.480 & -2.297 & 1\end{array}$

$\begin{array}{cccc}151.0 & 41.0 & & \\ -171.9065 & -.077993 & 2839.319 & 71.595\end{array}$

O.K.?

$\mathrm{Y}$

ENTER THE INDEX NUMBER OF MINERAL. (TYPE 〈STOP> TO EXIT) STOP

MORE MINERALS TO BE TYPED IN FROM THE TERMINAL?

N

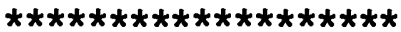

KEYWORD DATA BLOCKS

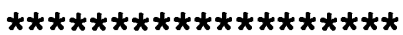

ENTER KEYWORD.

STEPS

STEPS

INPUT XSTEP(1)

0.0

INPUT XSTEP(2)

0.001

INPUT XSTEP(3)

0.005

INPUT XSTEP(4)

0.01

INPUT XSTEP(5)

0.05

$\begin{array}{lllll}0.0 & 0.001 & 0.005 & 0.01 & 0.05\end{array}$

O.K.? 
ENTER KEYWORD.

REACTION

REACTION

INPUT LREAC(1)

?

REACTION

LREAC

INDEX NUMBER OF ELEMENT FOR THE REACTION. LREAC MUST BE BEIWEEN 4 AND 30 INCLUSIVE. IF LREAC IS GRFATER THAN 30 THE PROGRAM CONSIDERS THIS CONSTITUENT TO BE H2 OR O2 AND ONLY USES CREAC AND THMEAN TO CHANGE THE OXIDATION STATE OF THE REACTION SOLUTION.

FORMAT (I4)

NOTE: FOR A LISTING OF MASTER SPECIES AND ELEMENTS, ENTER 〈IST〉.

INPUT LREAC(1)

32

INPUT CREAC(1)

1.

INPUT THMEAN(1)

4.

321 .

O.K.?

4.

$\mathrm{Y}$

$* * * * * * * * * * * * * * * * * * *$

KEYWORD DATA BLOCKS 


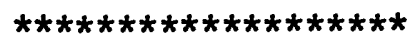

ENTER KEYWORD.

END

END

MORE SIMULATIONS?

N

**** STOP

$-36-$ 
Listing of constructed file: EXAMPLE.I

ADD OXYGEN AT PYRITE-CALCITE-GOETHITE EQUILIBRIUM

$013011000 \quad 51 \quad 0.0$

SOLUTION 1

PURE WATER

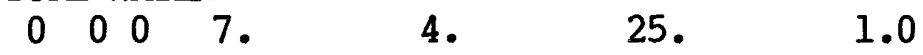

MINERALS

PYRITE $4 \quad 0.0 \quad-18.48 \quad 11.3$

$\begin{array}{llllll}1 & -2.0 & 2 & -2.0 & 8 & 1.0\end{array}$

$\begin{array}{lllll}\text { GOETHITE } & 3 & 3.0 & 0.486 & -14.48\end{array}$

$1151.0 \quad 32.0 \quad 1-3.0$

$\begin{array}{lllll}\text { CALCITE } & 2 & 4.0 & -8.480 & -2.297\end{array}$

$151.0 \quad 41.0$

$\begin{array}{llll}-171.9065 & -.077993 & 2839.319 & 71.595\end{array}$

STEPS

0.0

REACTION

321 .

$\begin{array}{lll}0.001 & 0.005 & 0.01\end{array}$

0.05

END

4. 
Attachment C. - Example using PHRQINPT to modify an existing reference file. 
EXAMPLE 2

\section{ENTER OUTPUT FILE NAME}

EXAMPLE.2

ENTER REFERENCE FILE NAME: (HIT 〈CR〉 TO OMIT)

EXAMPLE.1

TITLE CARD:

ADD OXYGEN AT PYRITE-CALCITE-GOEIHITE EQUILIBRIUM

ENTER OPTION. (1=KEEP, 2=REPLACE)

1

OPTION CARD:

$013011000 \quad 51 \quad 0.0$

ENTER OPTION. ( $1=$ KEEP, 2=MODIFY, 3=REPLACE)

2

OLD $\operatorname{IOPT}(1)=0$

KEEP THE OLD VALUE? (HIT 〈RETURN〉 IF YOU DO; IF NOT, REENTER THE DATA)

OLD IOPT $(2)=1$

KEEP THE OLD VALUE? (HIT 〈RETURN> IF YOU DO; IF NOT, REENTER THE DATA)

OLD $\operatorname{IOPT}(3)=3$

KEEP THE OLD VALUE? (HIT 〈RETURN〉 IF YOU DO; IF NOT, REENT'ER THE DATA)

OLD $\operatorname{IOPT}(4)=0$

KEEP THE OLD VALUE? (HIT 〈RETURN〉 IF YOU DO; IF NOT, REENTER THE DATA)

OLD IOPT $(5)=1$

KEEP THE OLD VALUE? (HIT 〈RETURN> IF YOU DO; IF NOT, REENTER THE DATA)

OLD $\operatorname{IOPT}(6)=1$

KEEP THE OLD VALUE? (HIT 〈RETURN> IF YOU DO; IF NOT, REENTER THE DATA)

OLD $\operatorname{IOPT}(7)=0$

KEEP THE OLD VALUE? (HIT 〈RETURN> IF YOU DO; IF NOT, REENTER THE DATA)

OLD $\operatorname{IOPT}(8)=0$

KEEP THE OLD VALUE? (HIT 〈RETURN> IF YOU DO; IF NOT, REENTER THE DATA)

OLD $\operatorname{IOPT}(9)=0$ 
KEEP THE OLD VALUE? (HIT 〈REIURN> IF YOU DO; IF NOT, REENTER THE DATA)

OLD NSTEPS $=5$

KEEP THE OLD VALUE? (HIT 〈REIURN> IF YOU DO; IF NOT, REENTER THE DATA) 7

OLD NCOMPS $=1$

KEEP THE OLD VALUE? (HIT 〈REIURN> IF YOU DO; IF NOT, REENTER THE DATA)

$01301100071 \quad 0.0$

O.K.?

$\mathrm{Y}$

$\star * * * * * * * * * * * * * * * * * * *$

KEYWORD DATA BLOCKS

$\star \star \star * * * * * * * * * * * * * * * * *$

KEYWORD:

SOLUTION 1

ENTER OPTION. (1=KEEP, 2=ELIMINATE)

1

SOLUTION

SOLUTION CARD:

PURE WATER

$\begin{array}{lllllll}0 & 0 & 0 & 7 . & \text { 4. } & 25 . & 1.0\end{array}$

ENTER OPTION. (1=KEEP, 2=MODIFY, 3=REPLACE)

2

OLD SOLUTION NUMBER=1

KEEP THE OLD VALUE? (HIT 〈RETURN> IF YOU DO; IF NOT, REENTER THE DATA)

SOLUTION 1

O.K.?

$\mathrm{Y}$

OLD HEAD=

PURE WATER

KEEP THE OLD VALUE? (HIT 〈REIURN> IF YOU DO; IF NOT, REENTER THE DATA) 
PURE WATER

O.K.?

$\mathrm{Y}$

OID NIOTS $=0$

KEEP THE OLD VALUE? (HIT 〈REIURN> IF YOU DO; IF NOT, REENTER THE DATA)

OLD $\mathrm{PH}=7$.

KEEP THE OLD VALUE? (HIT 〈REIURN> IF YOU DO; IF NOT, REENTER THE DATA)

OLD PE=4 .

KEEP THE OLD VALUE? (HIT <REIURN> IF YOU DO; IF NOT, REENTER THE DATA) 0.0

OLD TEMP $=25$.

KEEP THE OLD VALUE? (HIT <REIURN> IF YOU DO; IF NOT, REENTER THE DATA)

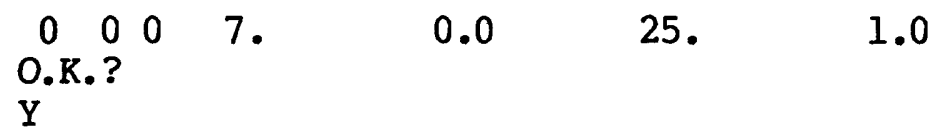

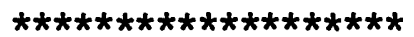

KEYWORD DATA BLOCKS

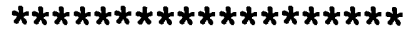

KEYWORD:

MINERALS

ENTER OPTION. (1=KEEP, 2=ELIMINATE)

1

MINERALS

MINERALS CARD:
PYRITE 4
$\begin{array}{lll}0.0 & -18.48 & 11.3\end{array}$
0
$1 \quad-2.0$
$2-2.0$
81.0
$42 \quad 2.0$

ENTER OPTION. ( $1=$ KEEP, $2=$ MODIFY, $3=$ =ELIMINATE)

1 
MINERALS CARD:

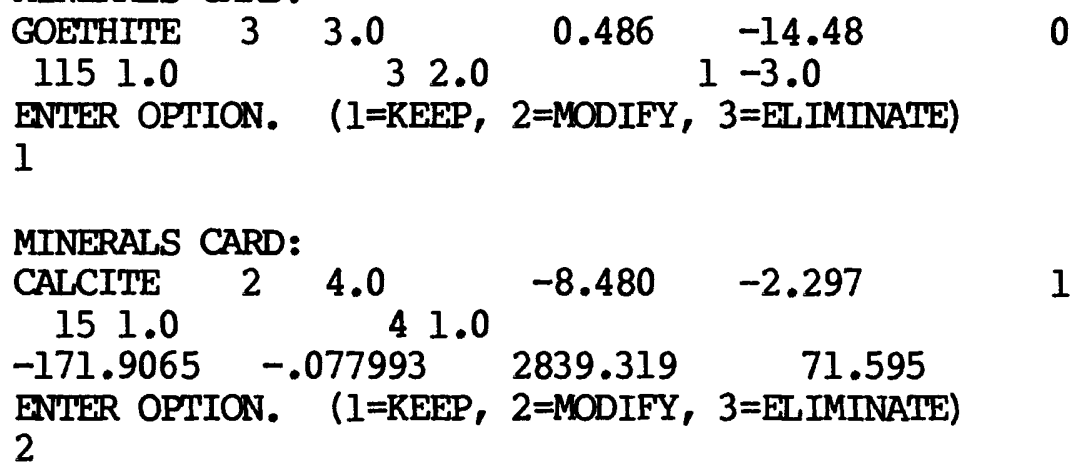


KEEP THE OLD VALUE? (HIT 〈RETURN〉 IF YOU DO; IF NOT, REENTER THE DATA)

OLD $\operatorname{LMIN}(2)=4$

KEEP THE OLD VALUE? (HIT 〈RETURN> IF YOU DO; IF NOT, REENTER THE DATA)

$\operatorname{OLD} \operatorname{CMIN}(2)=1.0$

KEEP THE OLD VALUE? (HIT 〈RETURN> IF YOU DO; IF NOT, REENTER THE DATA)

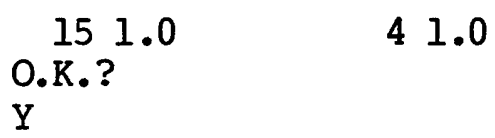

OLD $\operatorname{AMIN}(1)=-171.9065$

KEEP THE OLD VALUE? (HIT 〈RETURN> IF YOU DO; IF NOT, REENTER THE DATA)

OLD $\operatorname{AMIN}(2)=-.077993$

KEEP THE OLD VALUE? (HIT 〈RETURN> IF YOU DO; IF NOT, REENTER THE DATA)

OLD $\operatorname{AMIN}(3)=2839.319$

KEEP THE OLD VALUE? (HIT 〈RETURN> IF YOU DO; IF NOT, REENTER THE DATA)

OLD $\operatorname{AMIN}(4)=71.595$

KEEP THE OLD VALUE? (HIT 〈RETURN> IF YOU DO; IF NOT, REENTER THE DATA)

OLD $\operatorname{AMIN}(5)=$

KEEP THE OLD VALUE? (HIT 〈RETURN〉 IF YOU DO; IF NOT, REENTER THE DATA)

$\begin{array}{llll}-171.9065 & -.077993 & 2839.319 & 71.595\end{array}$

O.K.?

$\mathrm{Y}$

$\star \star \star * * * * * * * * * * * * * * * * *$

KEYWORD DATA BLOCKS

$\star * * * * * * * * * * * * * * * * * *$

KEYWORD:

STEPS

ENIER OPTION. (1=KEEP, 2=ELIMINATE)

1 
STEPS CARD:

$\begin{array}{lllll}0.0 & 0.001 & 0.005 & 0.01 & 0.05\end{array}$

ENTER OPTION. ( $1=$ KEEP, 2=MODIFY, 3=REPLACE)

2

OLD XSTEP $(1)=0.0$

KEEP THE OLD VALUE? (HIT 〈RETURN> IF YOU DO; IF NOT, REENTER THE DATA)

OLD XSTEP $(2)=0.001$

KEEP THE OLD VALUE? (HIT 〈RETURN> IF YOU DO; IF NOT, REENTER THE DATA)

OLD XSTEP $(3)=0.005$

KEEP THE OLD VALUE? (HIT 〈REIURN> IF YOU DO; IF NOT, REENTER THE DATA)

OLD XSTEP $(4)=0.01$

KEEP THE OLD VALUE? (HIT <RETURN> IF YOU DO; IF NOT, REENTER THE DATA)

OLD XSTEP $(5)=0.05$

KEEP THE OLD VALUE? (HIT 〈REIURN〉 IF YOU DO; IF NOT, REENTER THE DATA)

OLD XSTEP $(6)=$

KEEP THE OLD VALUE? (HIT 〈RETURN> IF YOU DO; IF NOT, REENTER THE DATA) 0.1

OLD XSTEP(7) =

KEEP THE OLD VALUE? (HIT 〈RETURN〉 IF YOU DO; IF NOT, REENTER THE DATA) 0.2

$\begin{array}{lllllll}0.0 & 0.001 & 0.005 & 0.01 & 0.05 & 0.1 & 0.2\end{array}$

O.K.?

$\mathrm{Y}$

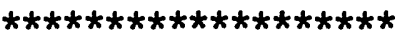

KEYWORD DATA BLOCKS

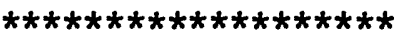


KEYWORD:

REACTION

ENTER OPTION. (1=KEEP, 2=ELIMINATE)

1

REACTION

REACTION CARD:

321.4 . 4

ENTER OPTION. (1=KEEP, 2=MODIFY, 3=REPLACE)

1

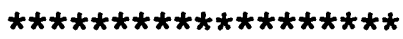

KEYWORD DATA BLOCKS

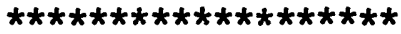

\section{KEYWORD:}

END

ENTER OPTION. (1=KEEP, 2=ELIMINATE)

1

END

MORE SIMULATIONS?

$\mathrm{N}$

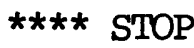


Listing of constructed file: EXAMPLE.2

ADD OXYGEN AT PYRITE-CALCITE-GOETHITE EQUILIBRIUM $01301100071 \quad 0.0$

SOLUTION 1

PURE WATER

$\begin{array}{lllll}0 & 0 & 0 & 7 .\end{array}$

0.0

25.

1.0

MINERALS

PYRITE

GOETHITE

1151.0

CALCITE

151.0

$\begin{array}{llll}4 & 0.0 & -18.48\end{array}$

$2-2.0$

$\begin{array}{lll}3 & 3.0 & 0.486\end{array}$

11.3

$8 \quad 1.0$

$420_{0}^{2.0}$

32.0

$1-3.0$

$\begin{array}{llll}2 & 4.0 & -8.480 & -2.297\end{array}$

1

0.2

$-171.9065$

41.0

$-.077993 \quad 2839.319$

71.595

STEPS

0.0

0.001

0.005

0.01

0.05

0.1

0.2

321.

4.

END 
Attachment D. - Source code listing of PHRQINPT. 
PROGRAM PHRQINPT

A 1

C
C
C
C
C
C
C
C
C
C
C
C
C
C
C
C
C
C
C
C
C
C
C
C
C
C
C
C
C
C
C
C

**PROGRAM TO FORMAT INPUT-DATA FOR PHREEQE**

A 2

A 3

A 4

A 5

THIS INTERACTIVE PROGRAM WILL SET UP THE INPUT FILE OF PHREEOE A 6

BY ASKING THE USER VALUES OF THE VARIABLES. ALL QUESTIONS

SHOULD BE SELF-EXPLANATORY. IF YOU DON'T UNDERSTAND THE

USE OF A CERTAIN VARIABLE, A SHORT EXPLANATION OF THAT

VARIABLE IS AVAILABLE BY ENTERING A "?". IN SOME CASES,

HELP IS ALSO OBTAINABLE BY ENTERING SOMETHING THAT IS

INCOMPATIBLE WITH THE VARIABLE OR JUST A $\langle C R\rangle$. TO BE

ON THE SAFE SIDE, HOWEVER, A "?" IS RECOMMENDED.

A 7

A 8

A 9

A 10

A 11

A 12

A 13

AFTER EACH RECORD OF CARD IS COMPLETED, IT WILL BE PRINTED

ON THE SCREEN AND YOU WILL BE ASKED WHETHER THIS CARD

IS ALL RIGHT. IF YOU ANSWER 'NO', THE PROGRAM WILL TAKE

THE VARIABLES ON THE CARD, PRINT THEM INDIVIDUALLY, AND YOU

WILL BE GIVEN THE CHANCE OF CORRECTING ANY OF THEM. IF YOU

ANSWER 'YES', THE PROGRAM WILL GO ON TO THE NEXT CARD AND YOU

WILU NOT HAVE ANY MORE CHANCE OF CORRECTING ANY VARIABLES ON

THAT CARD.

-WRITTEN BY GEORGE W. FLEMING AND L. NIEL PLUMMERSUMMER, 1980.

LAST UPDATE-AUGUST, 1983.

A 14

A 15

A 16

A 17

A 18

A 19

A 20

A 21

A 22

A 23

A 24

A 25

A 26

A 27

A 28

A 29

A 30

A 31

A 32

A 33

DIMENSION IOPT $(9), \operatorname{LT}(2,30), \operatorname{DTOT}(2,30), \operatorname{ADHSP}(250,2), \operatorname{ASP}(250,5)$

A 34

A 35

$1, \operatorname{LSP}(250,6), \operatorname{CSP}(250,6), \operatorname{AMIN}(2,100,5), \operatorname{XTEMP}(50), \operatorname{XSTEP}(50)$

$2, \operatorname{LREAC}(30), \operatorname{CREAC}(30)$, THMEAN (30), JSUB (11)

A 36

3,NELT (30) ,TGFW(30) ,NI (250) ,NSP (250) ,KFLAG (250) , ZSP (250) , ISDEL (250)

$4, \operatorname{THSP}(250), \operatorname{ALKSP}(250), \operatorname{NMINO}(2,100), \operatorname{THMIN}(2,100), \operatorname{MFLAG}(2,100)$

A 37

$5, \operatorname{LMIN}(2,100,10), \operatorname{CMIN}(2,100,10), \operatorname{IMTNERAL}(2), \operatorname{NSUM}(10), \operatorname{LSUM}(10,50)$

A 38

6 , IMORE (11) , TEMP (2) , PE (2) ,PH (2), $\operatorname{SDENS}(2), \operatorname{IUNITS}(2), \operatorname{HEAD}(2)$

A 39

$7, \operatorname{NIOTS}(2), \operatorname{IREQUIRED}(11), \operatorname{ICHECK}(2,4: 30), \operatorname{MUSED}(100)$

A 40

8, IORDER(11) ,NSOLUTION (2), $\operatorname{IALK}(2), \operatorname{SIMIN}(2,100), \operatorname{IMAX}(9)$

A 41

A 42

COMMON /REFF/ JOPTION, IOPEN, JLINE

COMMON /REFFI/ I

COMMON /PN/ NELAG

A 43

A 44

A 45

A 46

COMMON / PT/ MNAMEO, NMINOO (100), THMINO ,LKTOMO ,DHMINO ,MFLAGO (100)

A 47

1, SIMINO ,LMINO $(100,10)$, CMINO, AMINO , IMINO ,SUB, ICOLI, ICOL2 (0:30)

A 48

2 , ICOL3, ICOL4, SPEC, OPV (30)

A 49

REAL ICOL3 $(0: 30)$

A 50 
LOGICAL YN, EXIT,LIST,STOP,OK $\quad$ A 51

INTEGER GFLAG(250), OUT $\quad$ A 52

CHARACTER *80 TITLE, LINE, HEAD, JLINE(3) $\quad$ A 53

CHARACTER *72 TFILE $\quad$ A 54

CHARACTER *8 SUB (11), $\operatorname{KEYWORD(20),~TNAME(30),~} \operatorname{SNAME}(250), \operatorname{MNAME}(2,100)$ A 55

$1, \operatorname{SUNAME}(10), \mathrm{DELETE}, \operatorname{ICOLI}(0: 30), \operatorname{ICOL} 4(0: 30), \operatorname{CSP}, \operatorname{MNAMEO}(100)$ A 56

$2, \operatorname{SPEC}(30)$, CREAC, THMEAN, EQUIVWT, SUBO (11) $\quad$ A 57

CHARACTER * 12 OPTION, VO, PH, PE, TEMP, SDENS, TGEW, ZSP, THSP, DHA(250) A 58

1,ADHSP, ALKSP, LKTOSP (250), THMIN, LKTOM $(2,100), \operatorname{DHMIN}(2,100)$, SIMIN $\quad$ A 59

$2, X T E M P, X S T E P, D T O T, C M I N, D H S P(250)$,AMIN, ASP, BLANK, CMINO $(100,10) \quad$ A 60

3,THMINO (100), LKKTOMO (100),DHMINO (100), SIMINO (100),AMINO $(100,5) \quad$ A 61

DATA SUB/'SOLUTION', 'ELLEMENTS', 'SPECIES ', 'MINERALS', 'LOOK MIN', A 62

1 'TEMP ', 'STEPS ', 'REACTION', 'NEUTRAL ','SUMS ','END

2SUBO/'solution','elements','species ','minerals','look min', A 64

3'temp ','steps ','reaction','neutral ','sums ','end " A 65

DATA OPTION/'OPTION CARD'/BLANK/' $0.0 \quad \%$ A 66

DATA IMAX/ $1,2,6,3,1,1,2,1,1 /$ IORDER $/ 2,3,1,4,5,6,7,8,9,10,11 / \quad$ A 67

1 IMORE/ $1,1,1,1,1,0,0,0,0,1,0 /$ DELETE/'DELETE $\%$ A 68

C

C READ NECESSARY DATA AND INITIALIZE VARIABLES.

A 69

C

CALL READFILE

CLOSE (UNIT=11)

CLOSE (UNIT=12)

WRITE $(1,1)$

1 FORMAT ('ENTER OUTPUT FILE NAME')

READ $(1,20)$ TFILE

20 FORMAT (A72)

OPEN (UNIT=10, FILE=TFILE, STATUS= 'UNKNOWN')

C

ITIME $=0$

2 CALL OPEN (ITIME)

3 JOPEN=IOPEN

C

DO $101 \mathrm{~K}=1,11$

$\operatorname{IREQUIRED}(\mathrm{K})=0$

$101 \operatorname{JSUB}(K)=0$

DO $103 \mathrm{~K}=1,100$

$103 \operatorname{MUSED}(K)=0$

DO $104 \mathrm{~K}=1,250$

$104 \operatorname{ISDEL}(\mathrm{K})=0$

DO $105 \quad K=4,30$

DO $105 \mathrm{~K} 2=1,2$

A 70

A 71

A 72

A 73

A 74

A 75

A 76

A 77

A 78

A 79

A 80

A 81

A 82

A 83

A 84

A 85

A 86

A 87

A 88

A 89

A 90

A 91

A 92

$105 \operatorname{ICHECK}(\mathrm{K} 2, \mathrm{~K})=0$

A 93

DO $106 \mathrm{~K}=1,50$

A 94

$\mathrm{XSTEP}(\mathrm{K})=\mathrm{BLANK}$

A 95

A 96

$106 \mathrm{XTEMP}(\mathrm{K})=\mathrm{BLANK}$

A 97

DO $102 \mathrm{~K}=1,30$

A 98

$\operatorname{LREAC}(K)=0$

A 99

$\operatorname{CREAC}(\mathrm{K})=$ BLANK

A 100 
102 THMEAN $(\mathrm{K})=$ BLANK $\quad$ A 101

ISUB $=0$

A 102

IELEMENT=0

A 103

$\operatorname{IMINERAL}(1)=0$

A 104

IDELEIE $=0$

A 105

JDETEIEE $=0$

A 106

$\operatorname{IMINERAL}(2)=0$

A 107

ISPECIE $=0$

A 108

ISUM $=0$

A 109

NSTART=1

A 110

OUT $=10$

A 111

$I=0$

A 112

ISOL $=0$

A 113

IERROR $=0$

A 114

JOPTION $=0$

A 115

A 116

IF (IOPEN.EQ.0)GO TO 10

A 117

A 118

EXPLANATION OF SOME FLAGS:

A 119

A 120

ICHECK $\quad \longrightarrow$ MAKE SURE THAT FOR EVERY MASTER SPECIES

A 121 ENIERED, THERE IS A CORRESPONDING ELEMENT.

A 122

IERROR $\quad->$ FLAG TO SEE IF IT IS OK TO END THE

A 123

A 124

JSUB $\quad->$ KEEPS TRACK OF WHICH DATA BLOCK IS USED,

A 125

A 126

MUSED $\quad \longrightarrow$ KEEPS TRACK OF WHICH MINERAL DATA HAS BEEN

A 127

A 128

ISDEL $\quad \longrightarrow$ SPECIES TO BE DELETED.

A 129

IELEMENT $\longrightarrow$ NUMBER OF ELEMENTS.

A 130

IMINERAL (1) $\rightarrow$ NUMBER OF MINERALS.

A 131

IMINERAL (2) $\rightarrow>$ NUMBER OF LOOK MINS.

A 132

IMINO $\rightarrow$ NUMBER OF PRE-CONSTRUCTED MINERAL DATA.

A 133

ISPECIE $\quad->$ NUMBER OF SPECIES.

A 134

ISUM $\quad->$ NUMBER OF SUMS.

A 135

IDELETE $\quad->$ SET TO 1 IF ALL MINERALS ARE TO BE DELETED.

A 136

JDELETE $\quad->$ SET TO 1 IF ALL OLD SUMS ARE TO BE DELETED.

A 137

I $\quad->$ WHICH DATA BLOCK IS THE USER USING.

A 138

NFLAG $->$ SET TO 1 IF THE VARIABLE IS SEEN BY THE USER

A 139 THE SECOND TIME.

JFLAG $\quad->$ USER'S RESPONSE FLAG

A 140

IREQUIRED - >WHICH DATA BLOCKS ARE REQUIRED.

IMASTER $-\rightarrow$ IS THE SPECIES OR ELEMENT ENTERED 'MASTER'?

A 141

IOPEN

$-\rightarrow$ IF IT IS > 0, A REFERENCE FILE IS USED.

A 142

JOPTION $-\rightarrow$ IF IOPEN >0, WHAT DOES THE USER WANT TO DO

A 143

A 144 WITH EACH CARD.

A 145

ITIME $\quad->$ NUMBER OF TIMES SUBROUTINE OPEN IS CALLED.

A 146

IIINE $\quad->$ NUMBER OF LINES TO BE READ FROM THE REFERENCE

A 147 FILE.

A 148

IMAX

-->MAXIMUM VALUES PERMITTED FOR EACH OPTION.

A 149

A 150 


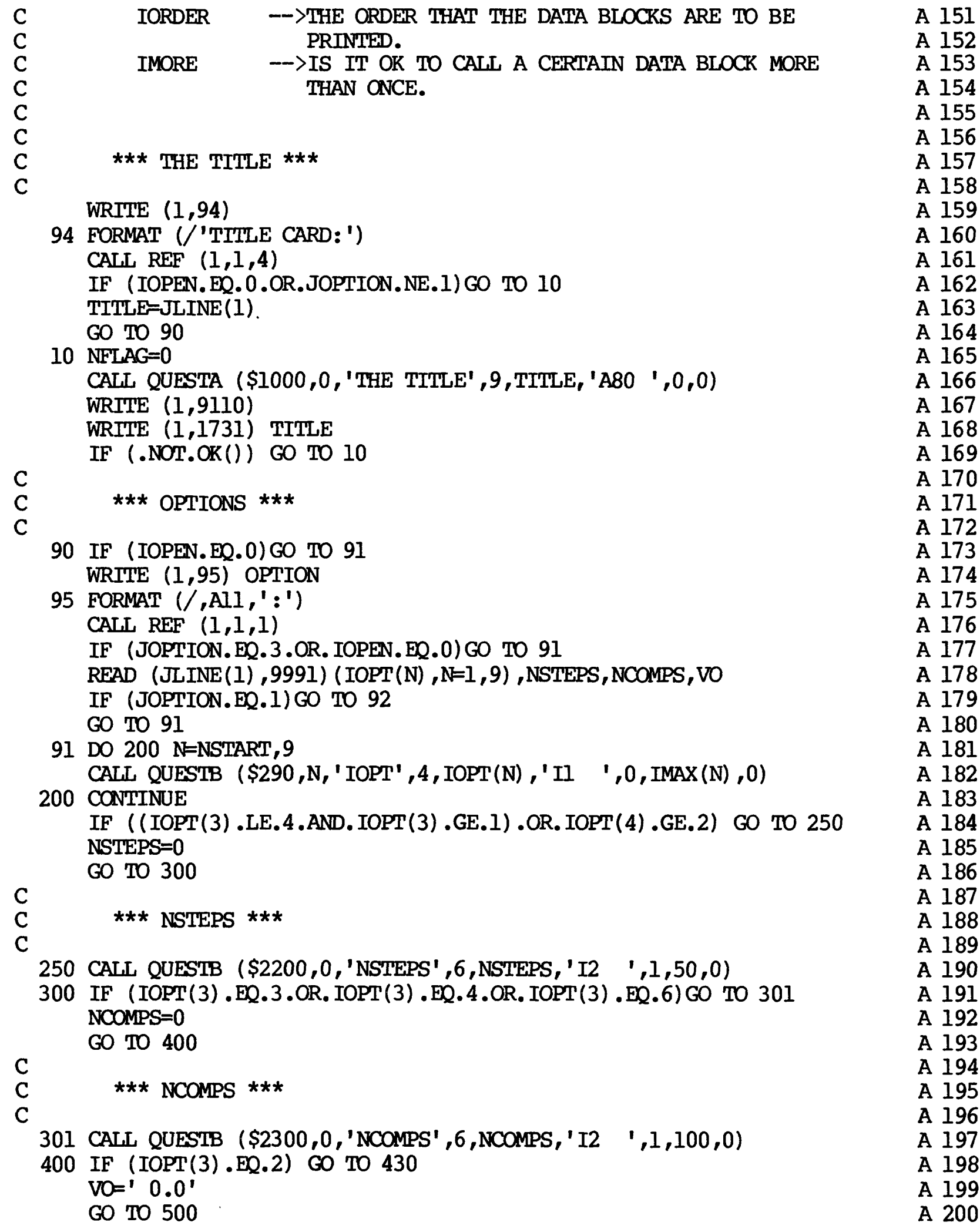


C

C

C

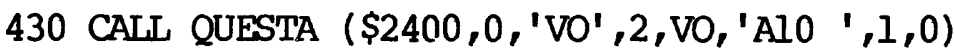

500 WRITE $(1,9110)$

WRITE ( 1,9991$)$ (IOPT (I) , I=1,9) ,NSTEPS, NCOMPS, VO

IF $(\mathrm{OK}())$ GO TO 92

NSTART=1

GO TO 91

C

C

C

$92 \operatorname{IF}$ (IOPT(3) .EQ .5.OR. IOPT(3) .EQ.6) IREQUIRED (4)=1

IF (IOPT (2).EQ.2) IREQUIRED (9) =1

IF (IOPT (3) .GE.1.AND. IOPT (3) .LE.4) IREQUIRED (7) =1

IF (IOPT (3) .EQ.3.OR. IOPT (3) .EQ.4.OR. IOPT (3) . EQ.6) IREQUIRED (8) =1

IF (IOPT (4) .NE. 0) IREQUIRED (6) $=1$

C

C

C

C

C

C

C

C

C

C

C

C

C

C

C

531 ISUB $=1$

KEYWORD DATA BLOCKS.

THE PROGRAM IS DESIGNED SO THAT THE DATA BLOCKS CAN BE ENTERED IN ANY ORDER. CERTAIN DATA BLOCKS, SUCH AS

'ELEMENTS', 'SPECIES', 'MINERALS', ETC., CAN BE CALLED

UPON MORE THAN ONCE. IN THAT CASE, NEW ELEMENTS, SPECIES, MINERALS, ETC., WILL JUST BE ATTACHED TO THE END OF THE DATA BLOCK. AT THE END OF THE SIMULATION, THE PROGRAM RE-ARRANGES THE DATA BLOCKS AND PRINTS THEM IN A PREFERRED ORDER.

IF YOU ACCIDENTALLY ENTERED A DATA BLOCK THAT YOU DO NOT WISH TO USE, ENTER 'EXIT' AS THE FIRST COMMAND AFTER YOU'VE ENTERED THE DATA BLOCK NAME.

A 201

A 202

A 203

A 204

A 205

A 206

A 207

A 208

A 209

A 210

A 211

A 212

A 213

A 214

A 215

A 216

A 217

A 218

A 219

A 220

A 221

A 222

A 223

A 224

A 225

A 226

A 227

A 228

A 229

A 230

A 231

A 232

A 233

$621 \operatorname{WRITE}(1,601)$

601 FORMAT $\left(/, 19\left('{ }^{\prime} '\right), /\right.$, 'KEYWORD DATA BLOCKS' $\left., /, 19\left(' *^{\prime}\right), / /\right)$

IF (IOPEN.EQ.0)GO TO 604

A 234

A 235

A 236

612 READ $(13,9001$, END=608, ERR=650) KEYWC 5 (ISUB) ,NSOL

DO $609 \mathrm{I}=1,11$

A 237

A 238

A 239

609 IF (KEYWORD(ISUB) . EQ.SUB(I)) GO TO 615

650 GO TO 612

A 240

A 241

C

C IF THE KEYWORD DATA BLOCKS ARE NOT ALLOWED, DON'T BOTHER

C TO ASK THE USER.

A 242

A 243

A 244

615 IF (I.EQ.6.AND.IOPT(4).EQ.0)GO TO 612

A 245

IF (I.EQ.7.AND. (IOPT(3) .EQ.0.OR. IOPT(3) .EQ.5.OR. IOPT(3) .EQ.6))

A 246

1 TO 612

IF (I.EQ.8.AND.NCOMPS.EQ.0)GO TO 612

A 247

IF (I.EQ.9.AND. IOPT(2).NE.2) GO TO 612

A 248

WRITE $(1,613)$

A 249

A 250 
613 FORMAT (/,'KEYWORD: ')

A 251

IF (I.EQ.1) GO TO 660

A 252

WRITE $(1,9050)$ KEYWORD ( ISUB)

A 253

GO TO 670

A 254

660 WRITE $(1,9001)$ KEYWORD (ISUB) ,NSOL

A 255

670 CALL REF $(0,1,2)$

A 256

IF (I.NE.II)GO TO 120

A 257

IOPEN $=0$

A 258

120 IF (JOPTION. EQ.1)GO TO 620

A 259

JOPTION $=0$

A 260

IF (I.EQ.11) GO TO 604

A 261

GO TO 621

A 262

608 IOPEN $=0$

A 263

GO TO 531

A 264

604 WRTTE $(1,603)$

603 FORMAT $(/$, ENTER KEYWORD. ')

A 265

READ $(1,20)$ LINE

A 266

READ (LINE, * ERR=622) IHELP

A 267

IF (IHELP.GT.11.OR. IHELP.LT.1)GO TO 4200

C

A 269

$\mathrm{C}$

HE ASRED FOR HELP..

A 270

C

GO TO $(4148,4150,4146,4152,4154,4156,4158,4160,4162,4164,4166)$,

A 271

A 272

1 IHELP

622 READ (LINE, 9050, ERR=4200) KEYWORD (ISUB)

A 273

A 274

A 275

READ (LINE, 810, ERR=820) NSOL

A 276

810 FORMAT $(9 \mathrm{X}, \mathrm{Il})$

A 277

GO TO 830

A 278

820 NSOL $=0$

A 279

830 DO $610 \quad \mathrm{I}=1,11$

A 280

IF (KEYWORD(ISUB).EQ.SUBO(I)) GO TO 620

A 281

IF (KEYWORD(ISUB).EQ.SUB(I)) GO TO 620

A 282

610 CONTINUE

A 283

GO TO 4200

A 284

A 285

A 286

A 287

A 288

A 289

A 290

GO TO 640

A 291

630 WRITE $(1,635)$

A 292

635 FORMAT $(/$, 'YOU HAVE ALREADY USED IT ONCE'/)

A 293

GO TO 621

640 WRITE $(1,639)$ KEYWORD(ISUB)

639 FORMAT $\left(/ /, 8\left({ }^{\prime}-1\right), /\right.$, A8, $\left./, 8\left({ }^{\prime}-1\right), / /\right)$

A 294

$\mathrm{II}=\mathrm{I}-3$

A 295

GO TO $(1700,1725,1750,3260,3250,3270,3280,3900,6000,7000,950)$, I

A 296 STOP

A 297

A 298

A 299

A 300 
C SOLUTION DATA BLOCK

A 301

C

A 302

C

1700 CONTINUE

ISOL $=$ ISOL+1

IF (ISOL.LE.2) GO TO 1510

A 303

WRITE $(1,1300)$

1300 FORMAT ('ONLY 2 SOLUT'TONS ARE ALLOWED. ')

A 304

A 305

A 306

ISOL $=2$

GO TO 531

1510 IF (IOPEN.EQ.0.AND.NSOL.EQ.0) GO TO 1739

A 307

A 308

A 309

A 310

IF (NSOL.EQ.1.OR.NSOL.EQ.2) GO TO 1500

A 311

JOPTION $=0$

GO TO 1492

A 312

A 313

A 314

1500 NSOLUT'TON (ISOL) $=$ NSOL

IF (IOPEN. EQ.0) GO TO 1400

A 315

WRITE $(1,1736)$ SUB(I)

A 316

A 317

1736 FORMAT (/,A8,' CARD:')

A 318

CALL REF $(2,1,0)$

READ (JLINE(1),1731) HEAD(ISOL)

A 319

A 320

1731 FORMAT (A80)

READ (JLINE (2), 9003) NIOTS(ISOL), IALK (ISOL), IUNITS (ISOL) ,PH

A 321

1 (ISOL), $\mathrm{PE}$ (ISOL), TEEMP(ISOL), SDENS(ISOL)

A 322

IF (NTOTS(ISOL).EQ.0) GO TO 1734

A 323

CALL REF $(1,1,0)$

READ (JLINE (1) ,9004) (LT(ISOL, M) ,DTOT (ISOL, M) , M=1,5)

A 324

A 325

IF (NTOTS(ISOL) .LE.5) GO TO 1734

A 326

A 327

LLINE=INT ( (NTOTS (ISOL) -1)/5)

A 328

DO 1738 KLINE=1,LLINE

A 329

CALL REF $(1,1,0)$

A 330

A 331

A 332

1 (KLINE+1) *5)

1734 CALL REF $(0,1,1)$

IF (JOPIION. EQ.1.AND. IALK(ISOL) .GT.0) GO TO 1752

A 333

A 334

IF (JOPTION.EQ.1)GO TO 531

C

C *** SOLUTTON NUMBER ***

A 335

A 336

A 337

C

1739 CALL QUESTB ( $\$ 1492,0$, ' SOLUTION NUMBER' ,15, NSOLUTION(ISOL) ,' Il

$1,1,2,1)$

IF (.NOT.EXIT) GO TO 1730

$\operatorname{JSUB}(1)=0$

1753 GO TO 531

1730 WRITE $(1,1001)$ NSOLUTTON( ISOL)

1001 FORMAT $(/$, 'SOLUTION' $, 1 \mathrm{X}, \mathrm{Il})$

IF (.NOT.OK()) GO TO 1739

A 338

A 339

A 340

A 341

A 342

A 343

A 344

A 345

A 346

1400 IREQUIRED (1) $=0$

A 347

C

C *** HEAD ***

A 348

A 349

C

A 350 


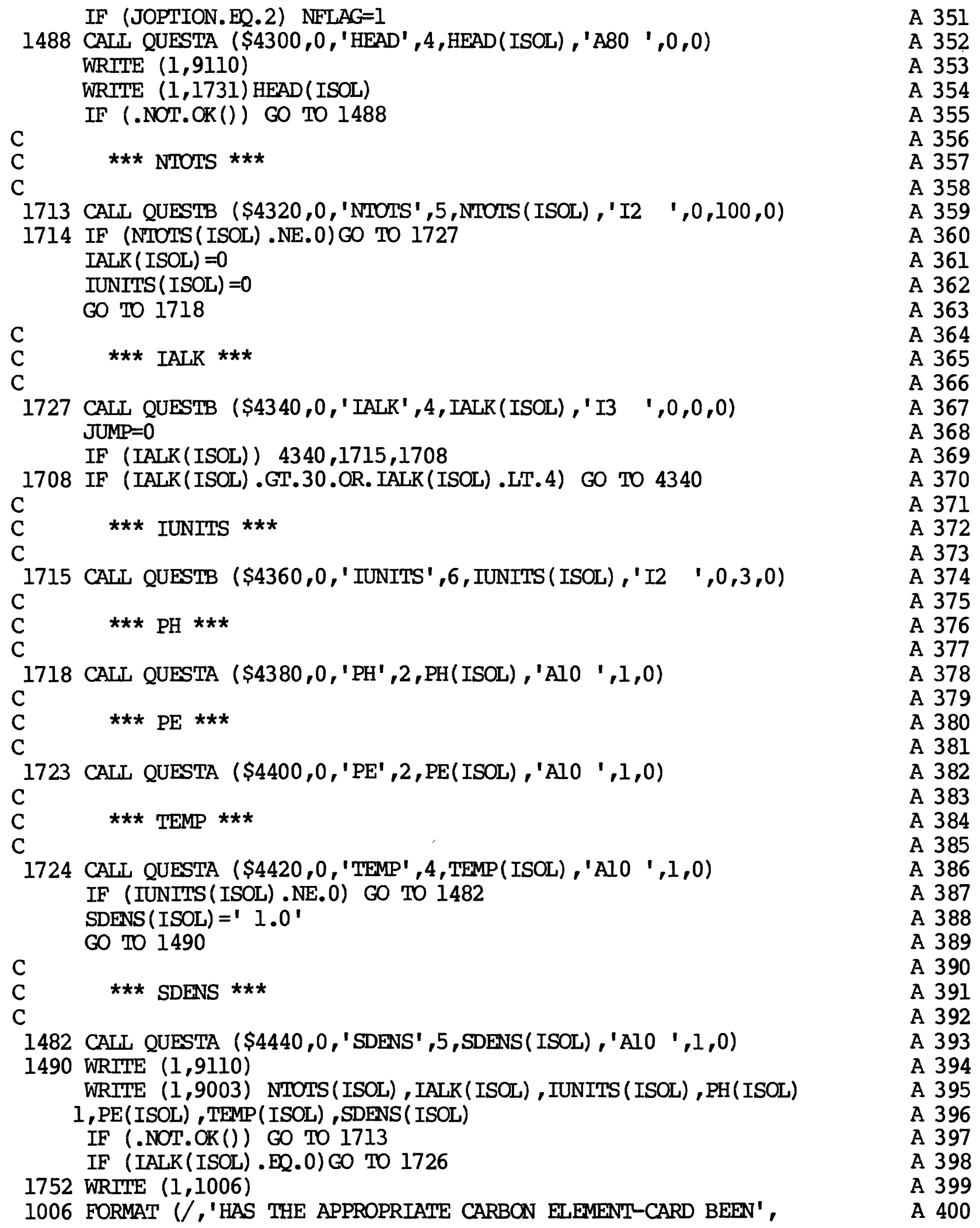


I' CONSTRUCTED?' )

A 401

JUMP $=1$

IF (.NOT.YN()) GO TO 1728

A 402

GO TO $(1726,1753,1726,1726)$, JOPTION+1

A 403

C ADD AN EXTRA ELEMENT CARD FOR HIM...

A 404

C

C

1728 WRITE $(1,1709)$

1709 FORMAT ( $/$, 'WHAT IS THE GRAM EQUIVALENT WEIGHT (GRAMS/EQUIVALENT'

A 405

A 406

A 407

A 408

$1, ')$ OF THE',/,'CHEMICAL SPECIES IN WHICH THE ALKALINITY IS',

A 409

2' REPORTED?')

WRITE $(1,1710)$

1710 FORMAT (//,'FOR EXAMPLE: ',/,19X, 'CACO3 50.0446 G/EQ',/,19X

A 410

A 411

A 412

1,' 'HCO3- $61.0171 \mathrm{G} / \mathrm{EQ}$ ',/,19X, 'CO3-- $30.0046 \mathrm{G} / \mathrm{EQ}$.',//)

$\operatorname{READ}(1,1731)$ LINE

READ (LINE, * ERR=1728) EQ

A 413

A 414

A 415

EQUIVWI=LINE $(1: 8)$

A 416

$\operatorname{JSUB}(2)=2$

WRITE $(1,1712)$

A 417

A 418

A 419

1712 FORMAT (//,' ELEMENTS DATA BLOCK WILL BE CONSTRUCTED AUTOMATICALLY'

A 420

$1, / /)$

IF (IELEMENT.LT.27) GO TO 1004

A 421

WRITE $(1,1002)$

A 422

A 423

1002 FORMAT $(1 X, 52(1 * '), /, 1 X$, 'WARNING: NUMBER OF ELEMENTS EXCEEDS ',

1 'MAXIMUM POSSIBLE. ',$/, 1 \mathrm{X}$, ' CARBON CARD IS DELETED. $1, /, 1 \mathrm{X}, 52(1 * 1) /)$ GO TO $(1726,1753)$, JOPTION+1

1004 IELEMENT=IELEMENT4I

TNAME ( IELEMENT) $=$ ' $C$ '

NEUT ( IELEMENT) = IALK ( ISOL)

TGFW ( IELEMENT) $=$ EQUIVWT

A 424

A 425

A 426

A 427

A 428

A 429

GO TO 1600

A 430

A 431

1601 IF (JOPTION.EQ.I) GO TO 1753

1726 IF (IUNITS (ISOL) .GE.2 .AND. IUNITS (ISOL) .LE.3.AND. IELEMENT. EQ.0)

1 IRFOUIRED (2) $=1$

A 432

A 433

IF (NTOTS(ISOL).EQ.0) GO TO 531

A 434

$1320 \quad M=1$

A 435

A 436

A 437

$1310 \quad \mathrm{~N} 2=1$

C

C $* * *$ LT ***

A 438

C

1326 CALL QUESTB $(\$ 4100, M, ' L T ', 2, L T($ ISOL,,$M), ' I 4 \quad$ ', $1,10000,2)$

A 439

A 440

IF (.NOT.LIST)GO TO 1057

1361 CALL LISTM

A 441

A 442

GO TO $(1326,1356)$, N2

A 443

A 444

$1057 \mathrm{~N} 2=2$

A 445

A 446

A 447

A 448

A 449

1356 CALL QUESTA (\$4100,M, 'DTOT' ,4,DTOT(ISOL,M),'All ',1,2)

A 450

IF (LIST) GO TO 1361 
$\mathrm{M}=\mathrm{M}+\mathrm{l}$

IF (M.LE.NIOTS(ISOL)) GO TO 1310

A 451

WRITE $(1,9110)$

A 452

WRITE ( 1,9004$)$ (LT(ISOL, M) ,DTOT(ISOL, $M), M=1$, NIOTS(ISOL))

A 453

IF (.NOT.OK()) GO TO 1320

A 454

GO TO 531

A 455

A 456

1725 CONTINUE

A 457

A 458

C

C

ELEMENTS DATA BLOCK

A 459

A 460

A 461

C

IELEMENT=IELEMENT+1

A 462

A 463

IF (IOPEN.EQ.0)GO TO 1729

A 464

1536 CALL REF $(1,0,0)$

IF (JOPTION.EQ.0) GO TO 1530

A 465

WRIIE $(1,1736)$ SUB(I)

A 466

WRITE $(1,1731)$ JLINE (1)

A 467

CALL REF $(0,0,3)$

A 468

GO TO $(1530,1531,1531,1536)$, JOPTION+1

A 469

A 470

1531 READ (JLINE(1),9102) TNAME (IELEMENT), NELT( IELEMENT), TGFW( IELEMENT) IREQUIRED (2) $=0$

IF (JOPTION.EQ.1) GO TO 1600

A 471

A 472

A 473

C

C $\quad * * *$ TNAME ***

A 474

A 475

C

1729 CALL QUESTA (\$4102,0, 'TNAME',5, TNAME(IELEMENT), 'A8 ',0,3)

A 476

IF (.NOT.LIST) GO TO 1549

CALL LISTM

GO TO 1729

A 477

A 478

A 479

A 480

1549 IF (.NOT.EXIT) GO TO 1550

A 481

1530 IELEMENT=IELEMENT-1

IF (IELEMENT. EQ.0) JSUB (2) $=0$

A 482

GO TO 531

A 483

1550 IREQUIRED (2) $=0$

A 484

C

C

*** NELT ***

A 485

A 486

C

CALL QUESTB ( $\$ 4104,0$, 'NELT',4,NELT(IELEMENT), ' I2 $\quad, 4,30,2)$

A 487

IF (.NOT.LIST) GO TO 1558

A 488

CALL LISTM

A 489

A 490

GO TO 1550

A 491

A 492

1558 DO $1547 \mathrm{M}=1$, IELEMENT-1

1547 IF (NELT(IELENENT) .EQ.NELT(M) ) GO TO 1548

A 493

A 494

GO TO 1570

1548 WRITE $(1,1551)$ NELT(M)

1551 FORMAT (/,'WARNING: ELEMENT \#',I2,' IS ALREADY ENTERED.'/)

A 495

A 496

A 497

A 498

A 499

C $\quad$ C** TGFW ***

A 500 
1570 CALL QUESTA ( $\$ 4106,0$, 'TGFW' ,4, TGEW(IELEMENT), 'Al0 ',1,2)

A 501

IF (.NOT.LIST) GO TO 1580

A 502

CALL LISTM

A 503

GO TO 1570

A 504

1580 WRITE $(1,9110)$

WRITE ( 1,9102 ) TNAME ( IELEMENT), NELT ( IELEMENT), TGEW( IELEMENT)

A 505

IF (.NOT.OK()) GO TO 1729

A 506

$\mathrm{C}$

KEEP TRACK OF ELEMENIS AND SPECIES

A 507

A 508

C

C

$1600 \operatorname{IF}$ (ICHECK (2,NELT(IELEMENT)) . EQ.1) GO TO 1557

A 509

A 510

$\operatorname{ICHECK}(1, \operatorname{NELT}$ ( IELEMENT) ) $=1$

A 511 GO TO 1575

A 512

A 513

$1557 \operatorname{ICHECK}(2, \operatorname{NELT}($ IELEMENT) ) $=0$

A 514

1575 IF (I.EQ.1)GO TO 1601

IF (IELEMENT. EQ.27) GO TO 531

A 515

IF (IOPEN.NE.0)GO TO 1725

A 516

WRITE $(1,1573)$

1573 FORMAT (/,'MORE ELEMENIS?')

A 517

A 518

IF (YN()) GO TO 1725

A 519

GO TO 531

A 520

A 521

1750 CONTINUE

A 522

A 523

A 524

A 525

A 526

A 527

A 528

ISPECIE=ISPECIE+1

A 529

IF (IOPEN.EQ.0)GO TO 1590

A 530

A 531

A 532

A 533

A 534

A 535

A 536

A 537

A 538

A 539

A 540

GO TO 1750

1521 READ (JLINE(1),9203) SNAME (ISPECIE) ,NSP (ISPECIE), KFLAG

A 542

1 (ISPECIE) ,GFLAG ( ISPECIE) , ZSP( ISPECIE) ,THSP (ISPECIE) ,DHA (ISPECIE)

A 543

2 , ADHSP (ISPECIE, 1) ,ADHSP (ISPECIE, 2), ALKSP (ISPECIE)

READ (JLINE (2), 9204) LKTOSP (ISPECIE) ,DHSP( ISPECIE) ,

A 544

1 (ASP (ISPECIE, MMM) ,MMM=1,5)

READ (JLINE (3), 9205) (LSP (ISPECIE, MMM) ,CSP(ISPECIE,MMM),

A 545

A 546

IMMM $=1, \mathrm{NSP}$ ( ISPECIE) )

A 547

IF (JOPTION.EQ.1) GO TO 1670

A 548

A 549

A 550 
C

1590 CALL QUESTB $\left(\$ 4110,0, ' I^{\prime}, 1, N I\right.$ (ISPECIE),'I3 ',4,250,1)

A 551 IF (.NOT.EXIT) GO TO 1654

1529 ISPECIE=ISPECIE-1

IF (ISPECIE.EQ. 0) JSUB ( 3 ) $=0$

IF (IOPEN.NE.0) GO TO 531

GO TO 1933

A 552

A 553

A 554

A 555

A 556

A 557

1654 WRITE $(1,9110)$

WRITE $(1,9202)$ NI (ISPECIE)

A 558

IF (.NOT.OK()) GO TO 1590

A 559

IF(ISDEL(ISPECIE) .NE.I) GO TO 1660

A 560

IF (JOPTION.EQ.2) GO TO 1750

A 561

GO TO 1934

A 562

C

*** SNAME $* * *$

A 563

A 564

C $\quad * * *$ SNAME ***

A 565

A 566

1660 CALL QUESTA (\$4112,0,'SNAME' ,5, SNAME(ISPECIE), 'A8 ',0,0)

A 567

C

C IS IT A MASTER SPECIE....

A 568

A 569

A 570

1670 IMASTER $=0$

IF (NI (ISPECIE) .LE.30.AND.NI (ISPECIE) .GT.3.AND. ISDEL( ISPECIE)

A 571

A 572

1.NE. 1) IMASTER=1

IF (JOPTION. EQ.1.AND. IMASTER.EQ.0) GO TO 1750

A 573

IF (IMASTER. EQ.0.OR. (NFLAG.EQ.1.AND.JOPTION.NE.2)) GO TO 1676

A 574

A 575

C

KEEP TRACK OF ELEMENTS AND SPECIES...

A 576

A 577

A 578

IF (ICHECK ( 1 ,NI(ISPECIE)).EQ.1)GO TO 1679

A 579

$\operatorname{ICHECK}(2, \mathrm{NI}$ (ISPECIE) $)=1$

A 580

GO TO 1595

A 581

$1679 \operatorname{ICHECK}(I, \mathrm{NI}$ (ISPECIE) $)=0$

1595 IF (JOPTION. EQ.1) GO TO 1750

A 582

A 583

A 584

C IF IT IS A MASTER SPECIES, A LOT OF VARIABLES CAN BE

A 585

A 586

c

DETERMINED WITHOUT ASKING THE USER...

A 587

NSP (ISPECIE) $=1$

KFLAG (ISPECIE) $=0$

$\operatorname{CSP}($ ISPECIE, 1$)=\prime^{\prime} 1.0^{\prime}$

A 588

A 589

LSP (ISPECIE, 1 ) =NI ( ISPECIE)

A 590

LKTOSP (ISPECIE) $=10.0^{\prime}$

A 591

DHSP (ISPECIE) $=10.0^{\prime}$

A 592

DO 1678 NII $=1,5$

A 593

A 594

1678 ASP(ISPECIE, NII) $=' 0.0^{\prime}$

A 595

GO TO 1690

A 596

A 597

C

$$
\text { *** NSP *** }
$$

A 598

A 599

1676 CALL QUESTB ( $\$ 4114,0,{ }^{\prime} \mathrm{NSP} ', 3, \mathrm{NSP}$ (ISPECIE), ' I3 $\left.\quad, 0,6,0\right)$

A 600 


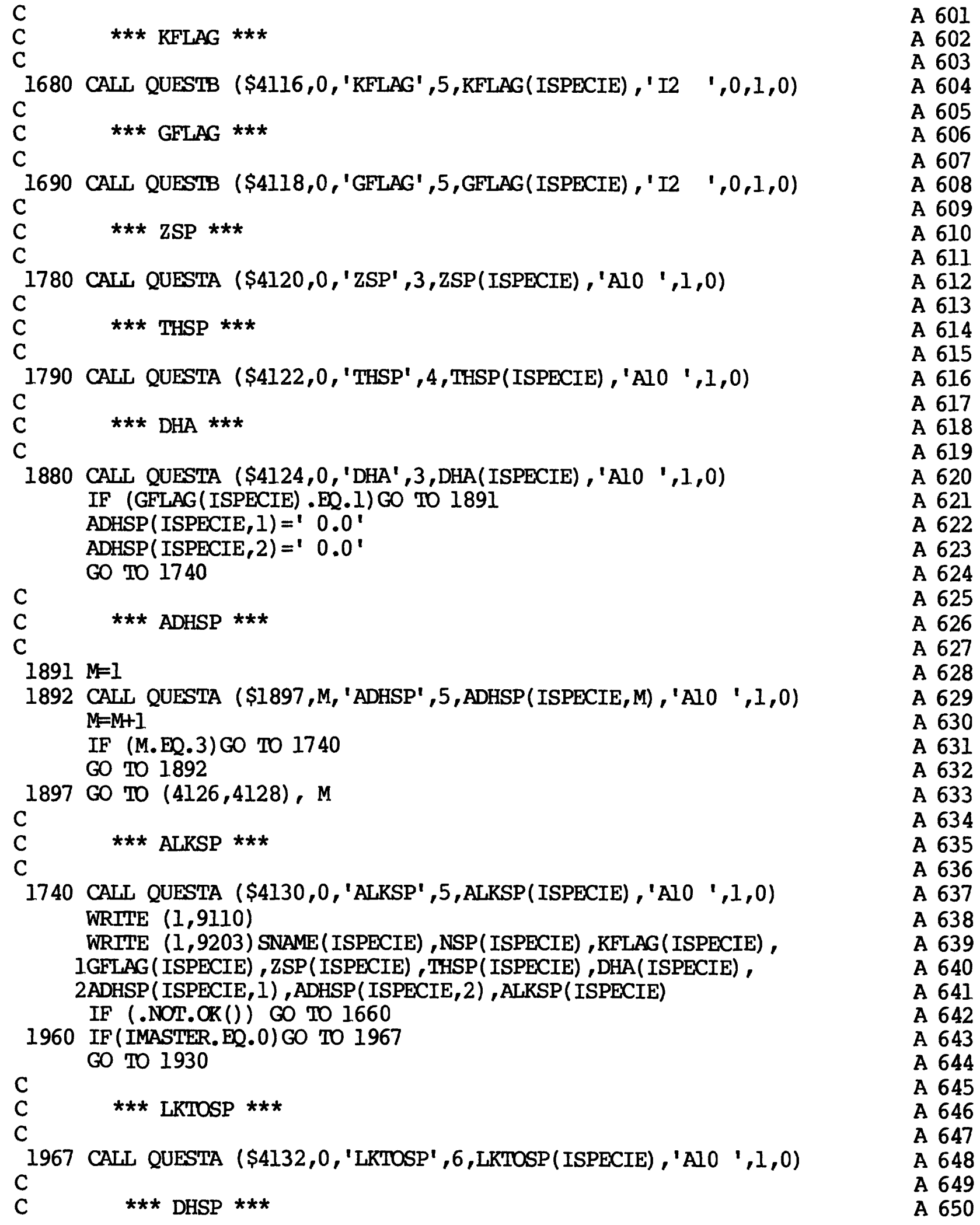


C

1970 CALL QUESTA ( $\$ 4136,0$, 'DHSP' ,4,DHSP(ISPECIE), 'Al0 ',1,0)

A 651 IF (KFLAG(ISPECIE) .EQ.1) GO TO 1986

A 652

C

C $\quad * * *$ ASP $* * *$

A 653

A 654

A 655

DO $1988 \mathrm{~K}=1,5$

A 656

A 657

1988 ASP (ISPECIE,K) $=$ ' $0.0^{\prime}$

A 658

$1986 \mathrm{~K}=1$

GO TO 1990

A 659

1987 CALL QUESTA (\$4138,K, 'ASP' ,3,ASP(ISPECIE,K), 'Al2 ',1,0)

A 660

$\mathrm{K}=\mathrm{K}+1$

IF (K.LT.6)GO TO 1987

A 661

A 662

1990 WRITE $(1,9110)$

WRITE (1,9204) LKTOSP(ISPECIE) ,DHSP (ISPECIE) , (ASP(ISPECIE, I8),

A 663

A 664

II $8=1,5)$

IF (.NOT.OK()) GO TO 1960

A 665

A 666

$1910 \mathrm{~K}=1$

IF (NSP(ISPECIE) .EQ.0) GO TO 1930

A 667

A 668

$1912 \mathrm{~K} 2=1$

A 669

$\mathrm{C}$

C

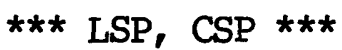

A 670

A 671

A 672

A 673

1915 IF (K2.EQ.1) CALL QUESTB ( $\$ 4142, K, ' L S P ', 3, L S P($ ISPECIE,K), ' I3 ',I $1,30,2)$

A 674

IF (K2.EQ.2) CALL QUESTA (\$4144, $\mathrm{K},{ }^{\prime} \operatorname{CSP} 1,3, \operatorname{CSP}(\operatorname{ISPECIE}, \mathrm{K})$, 'A7 ',1

A 675 $1,2)$

IF (.NOT.LIST) GO TO 1922

A 676

A 677

A 678

CALL LISTM

GO TO 1915

A 679

A 680

1922 IF (K2.EQ.2) GO TO 1923

A 681

$\mathrm{K} 2=2$

GO TO 1915

A 682

A 683

A 684

A 685

IF (K.GT.NSP(ISPECIE)) GO TO 1940

A 686

GO TO 1912

A 687

1940 WRITE $(1,9110)$

WRITE ( 1,9205$)$ (LSP (ISPECIE,MM) , CSP (ISPECIE, MM) ,MM=1, NSP (ISPECIE))

A 688

IF (.NOT.OK()) GO TO 1910

1930 IF (IOPEN.NE.0)GO TO 1750

A 689

A 690

WRITE $(1,1931)$

A 691

1931 FORMAT (/,'MORE SPECIES?')

A 692

IF (YN()) GO TO 1750

A 693

1933 WRITE $(1,1932)$

1932 FORMAT (/,'ANY SPECIES TO DELETE?')

A 694

A 695

1936 IF (.NOT.YN())GO TO 531

A 696

$\operatorname{ISDEL}($ ISPECIE+ 1$)=1$

A 697

$\operatorname{JSUB}(3)=1$

A 698

GO TO 1750

A 699

1934 WRITE $(1,1935)$

A 700 
1935 FORMAT (/,'MORE SPECIES TO DELETE?')

A 701 GO TO 1936

C

C

C MINERALS DATA BLOCK

C

C

3260 CONTINUE

IF (IMINO.EQ.0.OR. IOPEN.NE.0)GO TO 3100

A 702

A 703

A 704

A 705

A 706

A 707

A 708

A 709

C MINERAL DATA AVAIIABLE...

C WRITE $(1,3002)$

3002 FORMAT $(/$, 'PRE-CONSTRUCTED MINERAL DATA ARE AVAIIABLE. $\%$, 1 'DO YOU WISH TO HAVE ANY OF THEM?') IF (.NOT.YN())GO TO 3100

C

C

C

$3004 \operatorname{WRITE}(1,3003)(\mathrm{K}, \mathrm{MNAMEO}(\mathrm{K}), \mathrm{K}=1, \mathrm{IMINO})$

PRINT THE LIST OF MINERALS.....

3003 FORMAT $(/ 20(1 \mathrm{X}, 5(\mathrm{I} 3,1 \mathrm{X}, \mathrm{A} 8,2 \mathrm{X},:) /))$

3021 WRITE $(1,3005)$

3005 FORMAT $(/, '$ ENTER THE INDEX NUMBER OF MINERAL. (TYPE 〈STOP> TO'

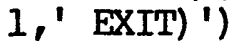

READ $(1,1731)$ LINE

IF (LINE( $1: 4)$.EQ. 'STOP'.OR.LINE(1:4).EQ. 'Stop') GO TO 3010 READ (LINE, *, ERR=3004) INDEX

IF (INDEX.GT. IMINO.OR. INDEX.LT.1)GO TO 3004

IF (MUSED (INDEX).EQ.1)GO TO 3012

$\operatorname{MUSED}($ INDEX) $=1$

GO TO 3013

3012 WRITE $(1,3014)$ INDEX

3014 FORMAT $(/ /, '$ MINERAL \# ',I3,' HAS ALREADY BEEN ENTERED. $1 / /)$ GO TO 3021

$3013 \operatorname{IMINERAL}(1)=\operatorname{IMINERAL}(1)+1$

IM=IMINERAL (1)

A 710

A 711

A 712

A 713

A 714

A 715

A 716

A 717

A 718

A 719

A 720

A 721

A 722

A 723

A 724

A 725

A 726

A 727

A 728

A 729

A 730

A 731

A 732

A 733

A 734

A 735

A 736

IREQUIRED ( 4$)=0$

A 737

$\operatorname{MNAME}(1$, IM) $=$ MNAMEO ( INDEX)

A 738

NMINO $(1$, IM) $=$ NMINOO $($ INDEX)

A 739

$\operatorname{THMIN}(1$, IM) $=$ THMINO $($ INDEX $)$

A 740

LKTOM ( 1, IM) =LKTOMO (INDEX)

A 741

$\operatorname{DHMIN}(1$, IM) $=$ DHMINO $($ INDEX)

A 742

MFLAG $(1$, IM) =MFLAGO (INDEX)

A 743

$\operatorname{SIMIN}(1$, IM) $=$ SIMINO (INDEX)

A 744

DO 3006 K2=1,NMINO (1, IM)

A 745

$\operatorname{LMIN}(1, \mathrm{IM}, \mathrm{K} 2)=\operatorname{LMINO}(\operatorname{INDEX}, \mathrm{K} 2)$

A 746

$3006 \operatorname{CMIN}(1, \operatorname{IM}, \mathrm{K} 2)=\operatorname{CMINO}$ (INDEX, K2)

A 747

3015 LFLAG $=1$

GO TO 3032

A 748

A 749

3020 DO $3008 \mathrm{~K} 2=1,5$

A 750 


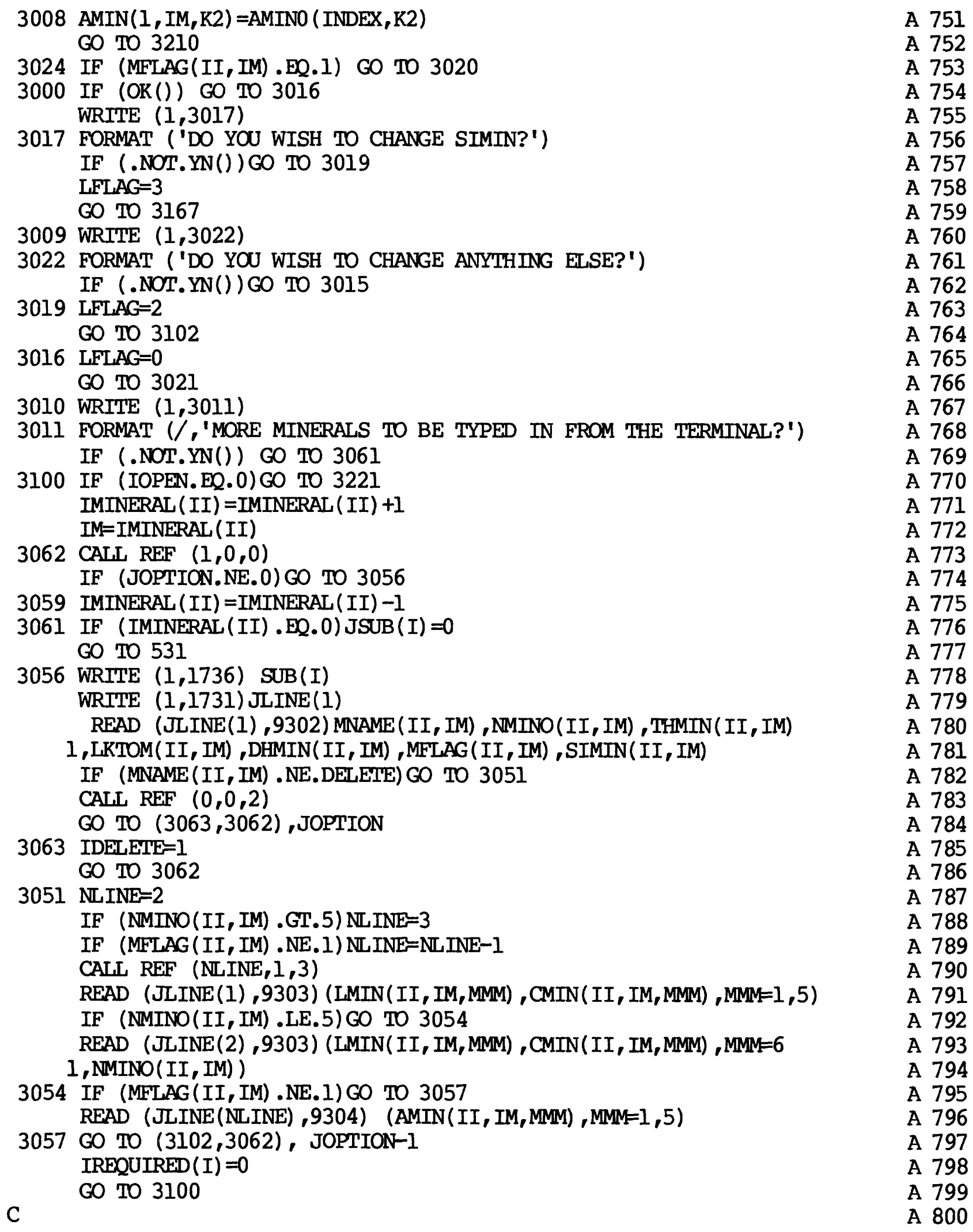

A 800

C 


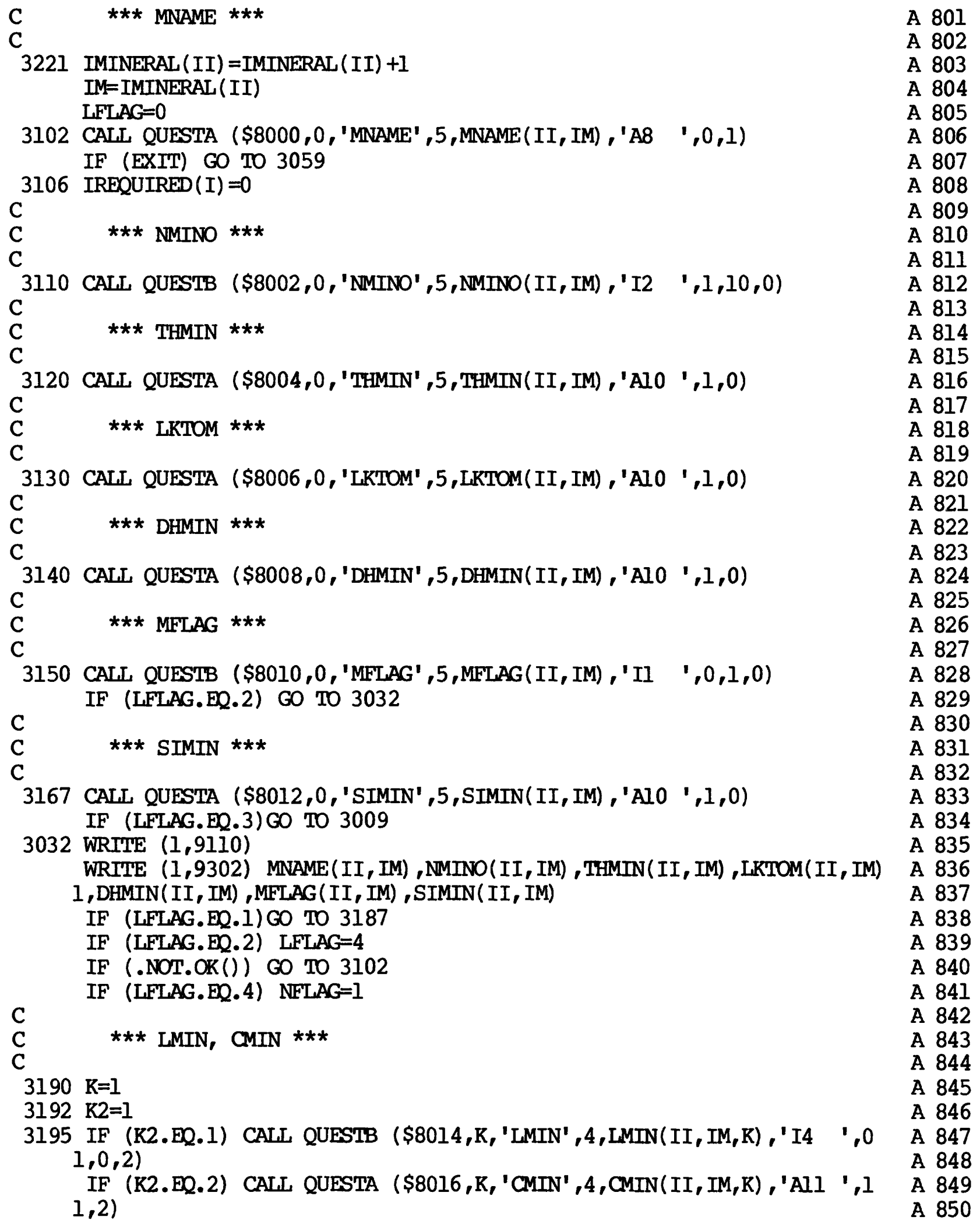


IF (.NOT.LIST)GO TO 3191

A 851

CALL LISTM

A 852

GO TO 3195

3191 IF (K2.EQ.2) GO TO 3186

A 853

$\mathrm{K} 2=2$

GO TO 3195

A 854

$3186 \mathrm{~K}=\mathrm{K}+1$

IF (K.LE.NMINO(II, IM)) GO TO 3192

A 855

A 856

A 857

WRITE $(1,9110)$

3187 WRITE $(1,9303)(\operatorname{LMIN}(\mathrm{II}, \mathrm{IM}, \mathrm{K}), \mathrm{CMIN}(\mathrm{II}, \mathrm{IM}, \mathrm{K}), \mathrm{K}=1$, NMINO(II, IM))

A 858

A 859

IF (LFLAG.EQ.1) GO TO 3024

A 860

IF (.NOT.OK()) GO TO 3190

A 861

IF (MFLAG (II, IM) .EQ.1) GO TO 3201

A 862

IF (LFLAG.EQ.4) GO TO 3016

A 863

IF (IOPEN.NE.0)GO TO 3100

A 864

GO TO 3010

A 865

C

*** AMIN ***

A 866

$\mathrm{C}$

C

3201 IF (LFLAG.EQ.4) NFLAG=1

A 867

A 868

A 869

A 870

$3200 \mathrm{~K}=1$

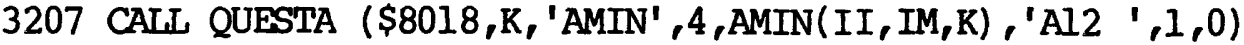

A 871

A 872 $\mathrm{K}=\mathrm{K}+1$

IF (K.LT.6)GO TO 3207

A 873

A 874

WRITE $(1,9110)$

3210 WRITE $(1,9304)$ ( $\mathrm{AMIN}(\mathrm{II}, \mathrm{IM}, \mathrm{K}), \mathrm{K}=1,5)$

IF (LFLAG.EQ.1) GO TO 3000

IF (.NOT.OK()) GO TO 3200

IF (LFLAG.EQ.4) GO TO 3016

A 875

A 876

A 877

A 878

A 879

IF (IOPEN.NE.0)GO TO 3100

A 880

GO TO 3010

A 881

3250 CONTINUE

A 882

A 883

A 884

LOOK MIN DATA BLOCK

A 885

A 886

A 887

IF (IMINERAL(2) .NE.0.OR. IOPEN.NE.0) GO TO 3100

A 888

WRITE $(1,3251)$

A 889

A 890

IF (YN()) IDELETE=1

IF (IDELETE. EQ.1) JSUB(I) $=1$

A 891

A 892

A 893

SINCE LOOK MIN IS ALMOST IDENTICAL TO MINERAL,

A 894 WHY NOT USE MINERAL SECTION AND SAVE SOME SPACE?

A 895

A 896

A 897

GO TO 3100

A 898

3270 CONTINUE

A 899

A 900 
C

IF (IOPT(4) .EQ.0) GO TO 3320

A 903

NITEMP=IOPT (4)

A 904

IF (IOPT (4).EQ.3) NTEMP=NSTEPS

A 905

IF (IOPEN.EQ.0) GO TO 3308

READ $(13,9501)$ (XTEMP (K3) , K3 $=1$, NTEMP)

A 906

A 907

WRITE $(1,1736)$ SUB $(I)$

A 908

WRITE $(1,9501)$ (XTEMP (K3), K3 $=1$, NTEMP)

A 909

CALL REF $(0,0,1)$

IF (JOPTION.NE.1) GO TO 3308

A 910

A 911

$\operatorname{IREQUIRED}(6)=0$

A 912

GO TO 531

A 913

C

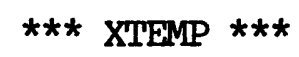

A 914

A 915

A 916

A 917

$3308 \mathrm{~K}=1$

3307 CALL QUESTA ( $\$ 8020, K, ' X T E M P ', 5, X T E M P(K), ' A l 01,1,1)$

A 918

A 919

IF (.NOT.EXIT) GO TO 3312

A 920

$\operatorname{JSUB}(6)=0$

A 921

GO TO 531

A 922

$3312 \mathrm{~K}=\mathrm{K}+1$

IF (K.LE.NIEMP) GO TO 3307

A 923

A 924

$\operatorname{IREQUIRED}(6)=0$

A 925

WRITE $(1,9110)$

WRITE $(1,9501)$ (XTEMP (K), $\mathrm{K}=1$, NTEMP)

A 926

A 927

IF (OK()) GO TO 531

A 928

GO TO 3308

A 929

3320 WRITE $(1,3321)$

A 930

3321 FORMAT $(/$, 'ERROR: TEMP DATA BLOCK NOT REQUIRED WHEN IOPT(4) =' $\left.1,0^{\prime}, / / /\right)$ $\operatorname{JSUB}(6)=0$ GO TO 531

A 931

A 932

A 933

A 934

3280 CONTINUE

A 935

A 936

A 937

STEPS DATA BLOCK

A 938

A 939

A 940

IF (IOPT(3) .EQ. 0.OR. IOPT(3) .EQ.5.OR. IOPT(3) .EQ.6) GO TO 3630

A 941 NSTEP=NSTEPS

IF (IOPT (3) .EQ.4) NSTEP=1

A 942

IF (IOPEN.EQ.0) GO TO 3608

A 943

A 944

READ $(13,9501)$ (XSTEP (K3) , K3=1, NSTEP)

WRITE $(1,1736)$ SUB (I)

A 945

WRITE $(1,9501)$ (XSTEP (K3), K3 $=1$, NSTEP)

A 946

CALL REF $(0,0,1)$

A 947

GO TO $(3801,3801,3608)$, JOPTION

A 948

A 949

$3801 \operatorname{IREQUIRED}(7)=0$

A 950 
IF (JOPTION.NE.2) GO TO 531

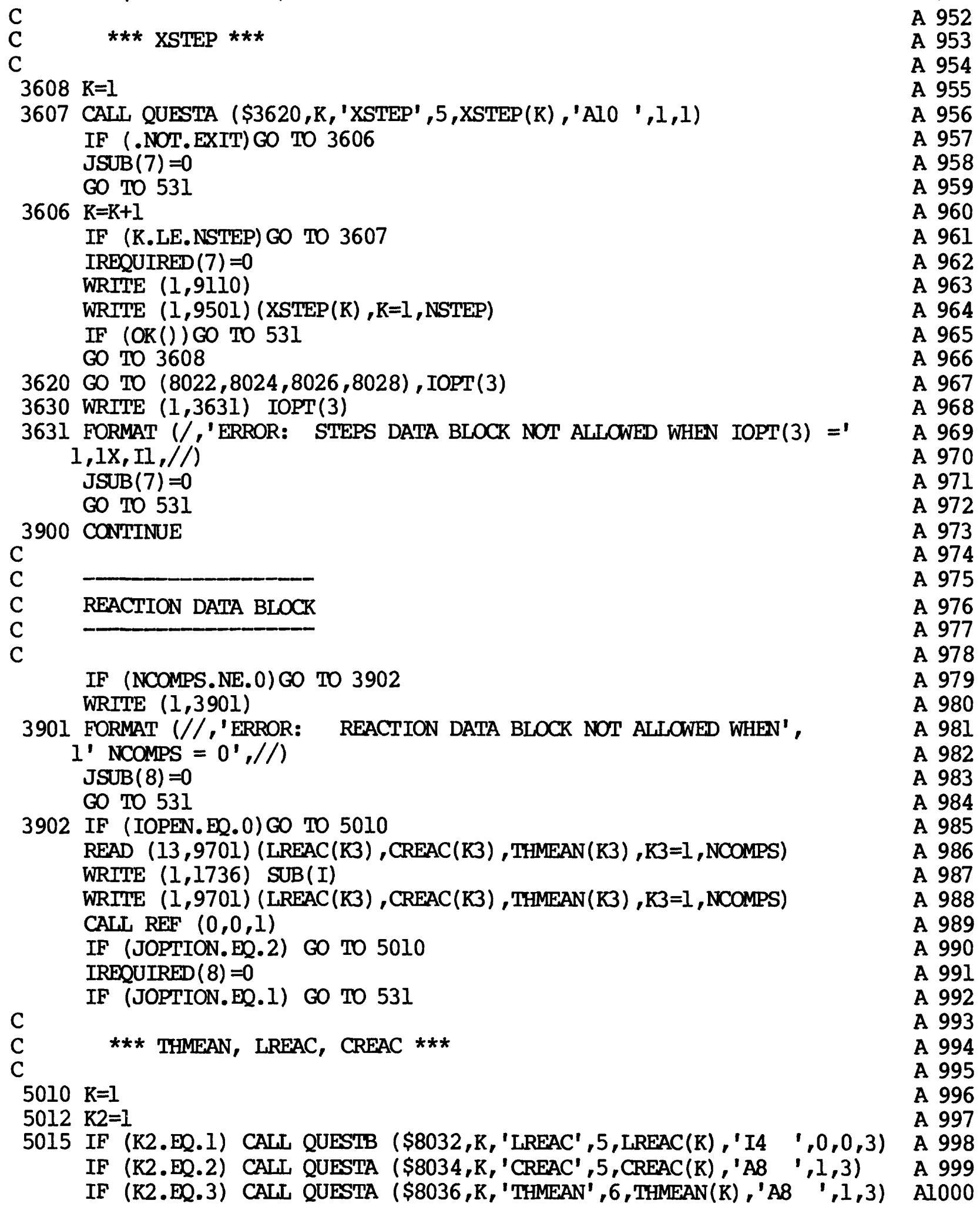


IF (.NOT. EXIT) GO TO 5023

Al001

$5300 \operatorname{JSUB}(8)=0$

Al002

GO TO 531

Al003

5023 IF (.NOT.LIST) GO TO 5025

Al004

CALL LISTM

Al005

GO TO 5015

Al006

5025 IF (K2.EQ.3) GO TO 5026

Al007

$\mathrm{K} 2=\mathrm{K} 2+1$

Al008

$\operatorname{IREOUIRED}(8)=0$

Al009

GO TO 5015

Al010

$5026 \mathrm{~K}=\mathrm{K}+1$

Al011

IF (K.GT.NCOMPS) GO TO 5027

Al012

GO TO 5012

Al013

5027 WRITE $(1,9110)$

Al014

WRITE $(1,9701)$ (LREAC (K) , CREAC (K) , THMEAN (K) , $\mathrm{K}=1$, NCOMPS)

Al015

IF (OK()) GO TO 531

Al016

GO TO 5010

Al017

6000 CONTINUE

Al018

C

Al019

Al020

C NEUTRAL DATA BLOCK

Al021

C

Al022

C

Al023

IF (IOPT(2) .NE.2) GO TO 6040

Al024

IF (IOPEN.EQ.0)GO TO 6010

Al025

CALL REF $(1,1,1)$

Al026

GO TO $(6100,6110,6110,6010)$,JOPTION+1

Al027

$6100 \operatorname{JSUB}(9)=0$

GO TO 531

Al028

Al029

6110 READ(JLINE(1) ,9801) LPOS, LNEG

Al030

$\operatorname{IREQUIRED}(9)=0$

Al031

IF (JOPTION.EQ.I)GO TO 531

Al032

C

*** LPOS ***

Al033

C

6010 CALL QUESTB ( $\$ 8038,0$, 'LPOS' $^{\prime} 4$, LPOS, 'I5 $\quad$ ',0,0,3)

IF (.NOT. EXIT) GO TO 6016

$\operatorname{JSUB}(9)=0$

GO TO 531

6016 IF (.NOT.LIST)GO TO 6017

CALL LISTM

GO TO 6010

Al034

Al035

Al036

Al037

Al038

Al039

Al040

Al041

Al042

6017 IREQUIRED $(9)=0$

Al043

C

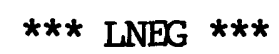

C

$\mathrm{C}$

6020 CALL QUESTB ( $\$ 8040,0$, 'LNEG' $^{4} 4, \mathrm{LNEG}$, ' I5 ' $\left., 0,0,2\right)$

IF (.NOT.LIST) GO TO 6030

Al044

Al045

Al046

A1047

CALL LISTM

Al048

GO TO 6020 
6030 WRITE $(1,9110)$

WRITE $(1,9801)$ LPOS, LNEG

Al051

IF (OK()) GO TO 531

GO TO 6000

6040 WRITE $(1,6041)$

6041 FORMAT (/,'ERROR: NEUTRAL DATA BLOCK IS REQUIRED ONLY IF IOPT' $1,,^{\prime}(2)=2^{\prime}, / / /$

$\operatorname{JSUB}(9)=0$

GO TO 531

7000 CONTINUE

Al052

Al053

Al054

Al055

Al056

Al057

Al058

Al059

Al060

C

Al061

Al062

C SUMS DATA BLOCK

Al063

Al064

C

IF (ISUM.NE.0.OR. IOPEN.NE.0) GO TO 7001

Al065

Al066

C

C DELETE ALL OLD SUMS....

Al067

Al068

C

Al069

WRITE $(1,7003)$

7003 FORMAT (/,'DO YOU WANT TO DELETE ALL OLD SUMS?')

Al070

Al071

IF (YN()) JDELETE=l

7001 ISUM $=$ ISUM+1

Al072

Al073

IF (IOPEN.EQ.0) GO TO 7010

Al074

Al075

7116 CALL REF $(1,0,0)$

IF (JOPTION.EQ.0) GO TO 7111

Al076

WRITE $(1,1736)$ SUB (I)

Al077

WRITE $(1,1731)$ JLINE(1)

Al078

READ (JLINE(1),9901) SUNAME (ISUM) ,NSUM(ISUM)

A].079

IF (SUNAME (ISUM) .NE.DELETE) GO TO 7120

Al080

CALL REF $(0,0,2)$

Al081

GO TO $(7111,7117,7116)$, JOPTION+1

Al082

7117 JDELETE=1

Al083

GO TO 7116

Al084

7120 READ $(13,9902)$ (LSUM (ISUM, MB) ,MB $=1$,NSUM(ISUM))

Al085

WRITE $(1,9902)$ (LSUM(ISUM, MB), MB $=1$, NSUM (ISUM))

Al086

CALL REF $(0,0,3)$

Al087

GO TO $(7111,7001,7010,7116)$, JOPTION+1

Al088

C

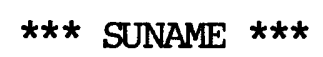

Al089

C

7010 CALL QUESTA ( $\$ 8042,0$,' SUNAME' , 6 ,SUNAME (ISUM), 'A8 ', 0,1 )

Al090

Al091

IF (.NOT.EXIT) GO TO 7020

Al092

Al093

7111 ISUM $=$ ISUM-1

Al094

IF (ISUM. EQ.0) JSUB (10) $=0$

Al095

GO TO 531

Al096

Al097

C

$$
\star \star \star * \text { NSUM } * * *
$$

Al098

Al099

7020 CALL QUESTB ( $\$ 8044,0$, 'NSUM' $^{\prime} 4$, NSUM( ISUM), 'I2 ',0,50,0)

Al100 


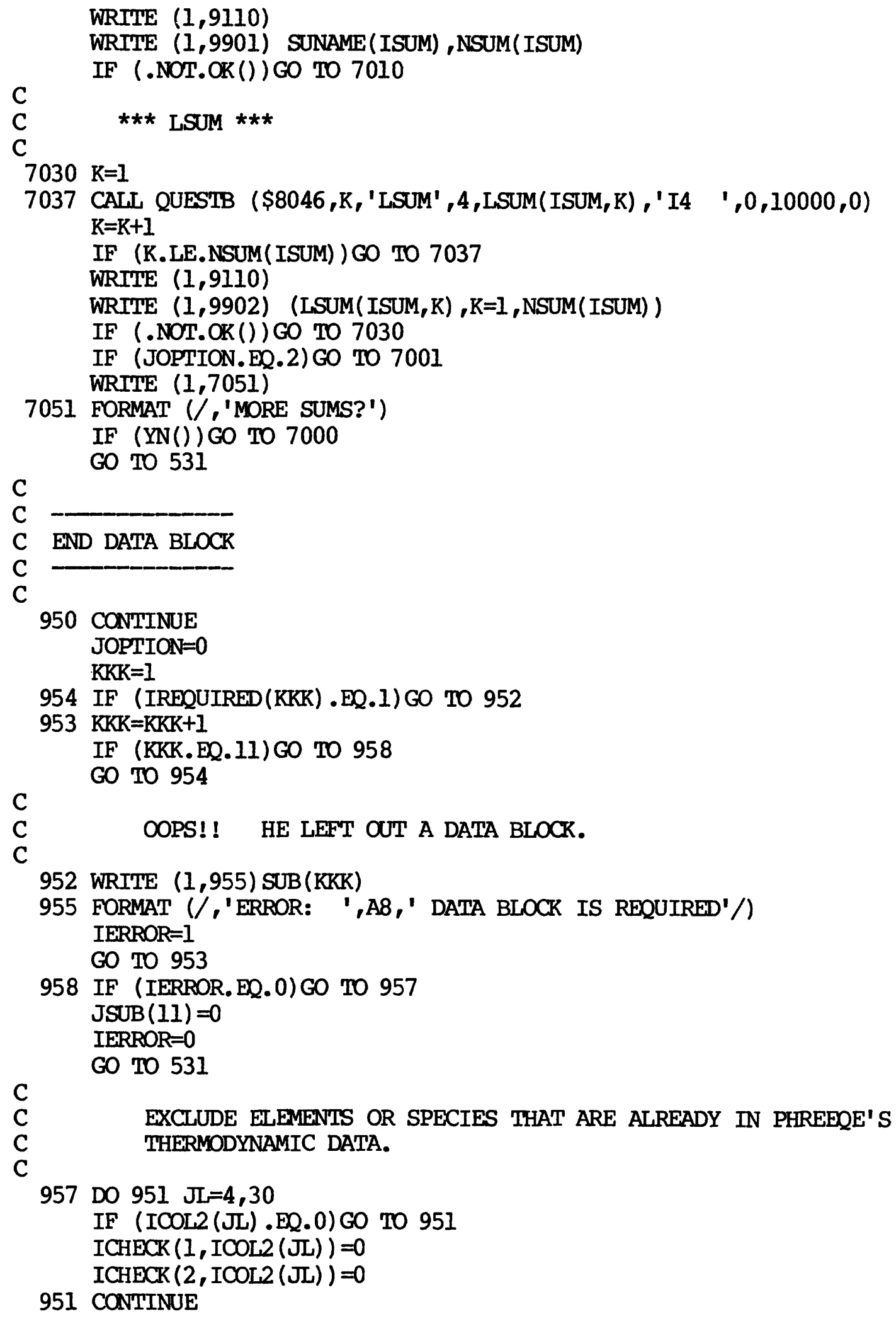


$\mathrm{JJ}=1$

Al15I

$943 \mathrm{JJJ}=4$

Al152

942 IF (ICHECK (JJ,JJJ) .EQ.1) GO TO $(944,945)$,JJ

Al153

949 JJJ=JJJ+1

IF (JJJ.EQ.31) GO TO 946

Al154

GO TO 942

Al155

$946 \mathrm{JJ}=\mathrm{JJ}+1$

Al156

IF (JJ.EQ.3) GO TO 947

Al157

GO TO 943

Al158

944 WRITE $(1,948)$ JJJ

948 FORMAT ('ERROR: SPECIES \#',I2,' WAS NOT ENTEERED.')

Al159

938 IERROR=1

GO TO 949

Al160

Al161

Al162

945 WRITE $(1,937)$ JJJ

937 FORMAT ('ERROR: ELEMENT \#',I2,' WAS NOT ENTERED.')

Al163

GO TO 938

Al164

Al165

947 IF (IERROR. EQ.0) GO TO 959

Al166

C

C HE ISN'T ALLOWED TO END.

Al167

Al168

Al169

C

IERROR $=0$

Al170

$\operatorname{JSUB}(11)=0$

Al171

GO TO 531

Al172

C

C EVERYTHING NEEDED IS PRESENT.

Al173

Al174

Al175

C

959 GO TO 9010

Al176

Al177

5001 WRITE $(1,5000)$

5000 FORMAT ('MORE SIMULATIONS?')

Al178

Al179

IF (.NOT.YN()) GO TO 50

Al180

IF (JOPEN.EQ.0) GO TO 5003

Al181

5006 READ $(13,1731$, END=5003) LINE

Al182

WRITE $(1,5005)$

Al183

5005 FORMAT(/,'DO YOU WISH TO USE THE NEXT SIMULATION IN YOUR',

I' REFERENCE?')

Al184

Al185

IF (.NOT.YN()) GO TO 5008

Al186

BACKSPACE 13

Al187

IOPEN $=1$

Al188

GO TO 3

Al189

Al190

5008 READ $(13,5009, E N D=5003)$ LINE

5009 FORMAT (A3)

IF (LINE(1:3) .EQ. 'END') GO TO 5006

Al191

GO TO 5008

Al192

Al193

5003 WRITE $(1,5002)$

5002 FORMAT $(/$, 'DO YOU WISH TO DEFINE THE PREVIOUS OUTPUT AS '

Al194

$1, /, 1 X$, ' YOUR NEW REFERENCE?')

Al195

IF (.NOT. IN ()) GO TO 2

Al196

Al197

C

WRITE THE OUTPUT ONTO THE REFERENCE FILE.

Al198

C

Al199

Al200 
OUT $=13$

CLOSE (UNIT=13)

Al201

OPEN (UNIT=13, FILE='REF' ,STATUS= 'UNKNOWN')

Al202

REWIND 13

Al203

GO TO 9010

Al204

999 ENDFILE (UNIT=13)

Al205

REWIND 13

Al206

IOPEN $=1$

Al207

C

LET'S TRY AGAIN...

Al208

C

C

GO TO 3

50 ENDFILE (UNIT=10)

STOP

Al209

Al210

Al211

Al212

C

9010 CONTINUE

Al213

Al214

Al215

C

C WRITE TO FILE.....

Al216

Al217

C

ITER=1

Al218

Al219

Al220

C

PRINT TITLE CARD.

Al221

C

C

WRITE (OUT, 1731) TITLE

Al222

Al223

Al224

C

C PRINT OPTION CARD.

Al225

Al226

WRITE (OUT, 9991) (IOPT( $I), I=1,9)$,NSTEPS, NCOMPS, VO

Al227

Al228

9991 FORMAT (9Il, 1X,2I2,6X, Al0)

Al229

DO $9999 \mathrm{~L}=1,11$

Al230

IF (JSUB(IORDER(L)) .LT.1) GO TO 9999

Al231

IF (IORDER(L).EO.1) GO TO 9000

Al232

WRITE (OUT, 9050) SUB ( IORDER(L))

Al233

9050 FORMAT (A8)

Al234

GO TO $(9100,9200,9300,9300,9500,9600,9700,9800,9900,9999)$, IORDER(L Al235

1) -1

Al236

Al237

C

PRINT SOLUTION DATA BLOCK.

Al238

Al239

C

9000 WRITE (OUT, 9001) SUB(1),NSOLUTION(ITER)

Al240

9001 FORMAT (A8,1X, II)

WRITE (OUT, 1731) HEAD(ITER)

Al241

Al2 242

WRITE (OUT,9003) NTOTS( ITER), IALK ( ITER), TUNITS (ITER) ,PH( ITER)

Al243

1, PE( ITER) ,TEMP( ITER), SDENS( ITER)

Al2 244

9003 FORMAT(I2, I3, I2, 3X, 4Al0)

Al245

IF (NTOTS(ITER) .EQ.0) GO TO 9005

Al246

WRITE (OUT, 9004) (LT( ITER, M) ,DTOT( ITER, M) ,M=1,NTOTS ( ITER))

Al2 247

9004 FORMAT $(6(5(\mathrm{I} 4, \mathrm{Al} 1),:, / /))$

Al2 248

9005 IF (ISOL. EQ. ITER) GO TO 9999

Al249

ITER=2

Al250 
GO TO 9000

Al251

C

C

PRINT ELEMENTS DATA BLOCK.

Al252

C

9100 DO 9103 MM=1, IELEMENT

9103 WRITE (OUT, 9102) TNAME(MM) ,NELT(MM) ,TGFW(MM)

Al253

Al254

9102 FORMAT (A8, 2X, I2 , 3X, Al0)

Al255

WRITE (OUT, 9110)

Al256

Al257

9110 FORMAT (1X)

Al258

GO TO 9999

Al259

C

C

PRINT SPECIES DATA BLOCK.

Al260

Al261

C

9200 DO 9206 MM=l, ISPECIE

Al262

Al263

WRITE (OUT, 9202) NI (MM)

Al264

9202 FORMAT (I3)

IF (ISDEL (MM) . EQ.0) GO TO 9207

Al265

WRITE (OUT, 9110)

GO TO 9206

9207 WRITE (OUT, 9203) SNAME (MM) ,NSP(MM) ,KFLAG (MM) ,GFLAG (MM) , ZSP(MM)

$1, \operatorname{THSP}(\mathrm{MM}), \mathrm{DHA}(\mathrm{MM}), \operatorname{ADHSP}(\mathrm{MM}, 1)$, ADHSP (MM, 2) ,ALRSP (MM)

Al266

Al267

Al268

Al269

Al270

Al271

Al272

Al273

WRITE (OUT, 9204) LKTOSP(MM) ,DHSP (MM) , (ASP (MM, M) , M=1,5)

Al274

Al2 275

WRITE (OUT, 9205) (LSP (MM, M) , CSP (MM, M) , M=l , NSP (MM))

Al276

9205 FORMAT $(6(\mathrm{I} 3, \mathrm{~A} 7))$

Al277

WRITE (OUT, 9110)

Al278

GO TO 9999

Al279

C

PRINT MINERALS OR LOOK MIN DATA BLOCK.

Al2 280

Al281

C

$9300 \mathrm{NM}=\operatorname{IORDER}(\mathrm{L})-3$

IF (NM.NE.2.OR. IDELETE.NE.1)GO TO 9301

Al282

Al 283

WRITE (OUT, 9050) DELETE

Al284

Al2 285

9301 IM=IMINERAL (NM)

Al286

DO $9305 \mathrm{MM}=1$, IM

Al2 287

WRITE (OUT, 9302) MNAME (NM, MM) , NMINO (NM, MM) ,THMIN (NM, MM) ,LKTOM(NM

Al288

$1, \mathrm{MM}), \operatorname{DHMIN}(\mathrm{NM}, \mathrm{MM}), \operatorname{MFLAG}(\mathrm{NM}, \mathrm{MM}), \operatorname{SIMIN}(\mathrm{NM}, \mathrm{MM})$

Al289

Al 290

9302 FORMAT $(\mathrm{AB}, 2 \mathrm{X}, \mathrm{I2}, 3 \mathrm{X}, 3 \mathrm{Al} 0,5 \mathrm{X}, \mathrm{Il}, 9 \mathrm{X}, \mathrm{Al} 0)$

WRITE (OUT, 9303) (LMIN(NM, MM, M) , CMIN(NM, MM, M) ,M=l, NMINO(NM, MM))

Al291

9303 FORMAT $(2(5(\mathrm{I} 4, \mathrm{All},:), /))$

Al292

IF (MFLAG (NM, MM) .NE.1) GO TO 9305

WRITE (OUT, 9304) (AMIN (NM, MM, M); M=1,5)

Al2 293

9305 CONTINUE

Al294

WRITE (OUT, 9110)

Al 295

Al296

9304 FORMAT (5Al2)

Al297

GO TO 9999

Al298

C

PRINT TEMP DATA BLOCK.

Al299

Al 300 
C

9500 WRITE (OUT,9501) (XTEMP( IF), IF $=1$, NTEMP)

Al301

9501 FORMAT $(7(8($ Al0,:),$/))$

GO TO 9999

C

C

C

9600 WRITE (OUT,9501) (XSTEP(IF), IF=1,NSTEP)

PRINT STEP DATA BLOCK. GO TO 9999

C

C

C

9700 WRITE (OUT, 9701) (LREAC (M) ,CREAC (M) ,THMEAN(M) ,M=1, NCOMPS)

9701 FORMAT $(8(4(14,2 A 8,:), /))$

GO TO 9999

C

C PRINT NEUTRAL DATA BLOCK.

C

9800 WRITE (OUT, 9801) LPOS, LNEG

9801 FORMAT (2I5)

GO TO 9999

Al302

Al303

Al304

Al305

Al306

Al307

Al308

Al309

Al310

Al311

Al312

Al313

Al314

Al315

Al316

Al317

Al318

Al319

Al320

Al321

C

C PRINT SUMS DATA BLOCK.

Al322

Al323

C

9900 IF (JDELETE.NE.1) GO TO 9904

Al324

Al325

WRITE (OUT, 9302) DELETE

Al326

9904 DO 9903 MM=1, ISUM

WRITE (OUT, 9901) SUNAME (MM), NSUM(MM)

Al327

Al328

9901 FORMAT (A8, 2X, I2)

9903 WRITE (OUT, 9902) (LSUM (MM, M) , MEl, NSUM(MM))

Al329

Al330

9902 FORMAT(20I4)

WRITE (OUT, 9110)

9999 CONTINUE

Al331

Al332

Al333

C

IF (OUT.EQ.10) GO TO 5001

Al334

GO TO 999

Al335

Al336

C

C HELP MESSAGES....

Al337

Al338

Al339

290 NSTART $=\mathrm{N}$

GO TO $(2000,2020,2040,2060,2080,2100,2120,2140,2160)$,N

1000 WRITE $(1,1010)$

1010 FORMAT (/1X, 'TITLE CARD' ,2X, 'TITLE', /, 1X, 'FORMAT (A80) ', $1 /, 1 X, '$ EIGHTY CHARACTERS OF TITLES OR COMMENTS. $1 / /)$ GO TO 10

2000 WRITE $(1,2010)$ OPTION

2010 FORMAT $(/ 1 \mathrm{X}, \mathrm{All}, /, 13 \mathrm{X}, \mathrm{IOPT}(1)=0$, NO PRINT OF',

1' THERMODYNAMIC DATA OR COEFFICIENTS' $/, 26 \mathrm{X}$, 'OF AQUEOUS',

Al340

Al341

Al342

Al343

Al344

Al345

Al346

Al347

Al348

2' SPECIES. ' $, / /, 21 \mathrm{X},{ }^{\prime}=1$, PRINT THE AQUEOUS MODEL DATA',

Al349

3' (WHICH ARE STORED',/26X,'ON DISK) ONCE DURING THE ENTIRE',

Al350 


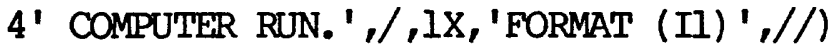

Al351 GO TO 91

2020 WRITE $(1,2030)$ OPTION

$2030 \operatorname{FORMAT}\left(/ 1 \mathrm{X}, \mathrm{All}, /, 13 \mathrm{X}, \mathrm{IOPT}^{2}(2)=0\right.$, INITIAL SOLUTIONS',

I' ARE NOT TO BE CHARGE BALANCED. ', /,26X, 'REACTION SOLUTIONS',

2' MAINTAIN THE INITIAL CHARGE',$/, 26 \mathrm{X}$, IMBALANCE. $^{\prime}, / /, 21 \mathrm{X},{ }^{\prime}=1,1$,

$3 '$ PH IS ADTUSTED IN INITIAL SOLUTION(S) TO', /,26X, 'OBTAIN CHARGE',

4 ' BALANCE. ' $, / /, 21 \mathrm{X},{ }^{\prime}=2$, THE TOTAL CONCENTRATION OF ONE OF THE',

5 ' ELEMENTS', /,26X, ' (EXCEPT H OR O) IS ADUUSTED TO OBTAIN',

6 ' ELECTRICAL',$/, 26 \mathrm{X}$, 'BALANCE. NEUTRAL INPUT IS REQUIRED. $1, /, 1 \mathrm{X}, \mathrm{F}$

7ORMAT (II),$/ / /)$

GO TO 91

2040 WRITE $(1,2050)$ OPTION

2050 FORMAT $\left(/ 1 \mathrm{X}, \mathrm{All}, /, 13 \mathrm{X}, \mathrm{IOPT}^{2}(3)=0\right.$, NO REACTIONS ARE',

' ' MODELED. ONLY THE INITIAL', $/, 26 \mathrm{X}$, ' SOLUTIONS ARE SOLVED. $1 / /$,

$221 \mathrm{X},{ }^{\prime}=1$, SOLUTION 1 IS MIXED (A HYPOTHETICAL CONSTANT',$/, 26 \mathrm{X}$,

3 'VOLUME PROCESS) WITH SOLUTION 2 IN SPECIFIED',/,26X, 'REACTION',

$4 '$ STEPS. STEPS INPUT AND A VALUE FOR',/,26X, 'NSTEPS ARE REQUIRED'

$5, '$. MINERALS INPUT MAY BE',$/, 26 \mathrm{X}$, ' INCLUDED. ' $, / /, 21 \mathrm{X},{ }^{\prime}=2,{ }^{\prime}$,

$6^{\prime}$ SOLUTION 1 IS TITRATED WITH SOLUTION 2 IN SPECI- $1, /, 26 \mathrm{X}$,

7 'FIED REACTION STEPS. STEPS INPUT, A VALUE FOR',/,26X,'NSTEPS,',

8' AND A VALUE FOR VO ARE REQUIRED. ',/,26X,'MINERALS INPUT MAY',

9' BE INCLUDED. ' $, / /, 21 \mathrm{X}, '=3, \mathrm{~A}^{\prime}$,

!' STOICHIOMETRIC REACTION IS ADDED IN SPECIFIED', /,26X, 'REACTION',

a' STEPS. REACTION INPUT, STEPS INPUT, ',$/, 26 \mathrm{X}$, 'A VALUE FOR',

\#' NSTEPS, AND A VALUE FOR NCOMPS ARE',$/, 26 \mathrm{X}$, 'REQUIRED. MINERALS',

\$' INPUT MAY BE INCLUDED. '///' HIT <RETURN> FOR MORE INFORMATION.') $\operatorname{READ}(1,20)$ LINE

WRITE $(1,2055)$

2055 FORMAT $\left(21 \mathrm{X},{ }^{\prime}=4\right.$, A NET STOICHIOMEIRIC',

$\wedge$ REACTION IS ADDED IN NSTEPS', $/, 26 \mathrm{X}$, ' EQUAL INCREMENTS. REACTION'

$\&, '$ INPUT, STEPS INPUT, $1, / 26 \mathrm{X},{ }^{\prime}$ A VALUE FOR NSTEPS, AND A VALUE FOR

* NCOMPS ARE' $/, 26 \mathrm{X}$, 'REQUIRED. MINERALS INPUT MAY BE INCLUDED.' ,

( 1 ONLY', $/, 26 \mathrm{X}$, 'ONE VALUE FOR THE TOTAL REACTION IS READ IN STEPS.

$1 ', / /, 21 \mathrm{x}, '=5$, SOLUTION NUMBER I IS EQUILIBRATED WITH MINERAL',

$-/, 26 \mathrm{X}$, ' PHASES ONLY. NO OTHER REACTION IS PERFORMED. $1, /, 26 \mathrm{X}$,

$=$ 'MINERALS INPUT IS REQUIRED. ' $, / /, 21 X, '=6$, A REACTION IS ADDED',

$+'$ TO SOLUTION I UNTIL EQUI- $1, /, 26 \mathrm{X}$, 'LIBRIUM IS ATTAINED WITH THE',

I' FIRST PHASE IN',/,26X,'MINERAL INPUT (EQUILIBRIUM WITH OTHER',

:' MINERALS',$/, 26 \mathrm{X}$, ' PHASES IS MAINTAINED THROUGHOUT THE REACTION) ',

$/ ' . ', /, 26 \mathrm{X}$, 'REACTION INPUT, A VALUE FOR NCOMPS, AND MINERALS',/,

] 26X, ' INPUT ARE REQUIRED. NO STEPS INPUT IS REQUIRED. ', /,26X,

['NOTE: THERE SHOULD BE A COMMON ELEMENT IN THE',/,26X, 'REACTION',

$\sim$ AND THE FIRST PHASE IN MINERALS INPUT.',$/, 1 \mathrm{X}$, FORMAT (Il) $\left.^{\prime}, / /\right)$

GO TO 91

2060 WRITE $(1,2070)$ OPTION

2070 FORMAT $\left(/ 1 \mathrm{X}, \mathrm{All}, /, 13 \mathrm{X},{ }^{\prime} \mathrm{IOPT}(4)=0\right.$, THE TEMPERATURE OF',

I' THE REACTION SOLUTION IS', $/, 26 \mathrm{X}$, 'A) THE SAME AS THE INITIAL',

2' SOLUTION IF ADDING', /,26X, 'A REACTION, OR B) CALCULATED LINEARLY

3 FROM THE',$/, 26 \mathrm{X}$, 'END MEMBERS IF MIXING OR TITRATING. NO TEMP',

Al352

Al353

Al354

Al355

Al356

Al357

Al358

Al359

Al360

Al361

Al362

Al363

Al364

Al365

Al366

Al367

Al368

Al369

Al370

Al371

Al372

Al373

Al374

Al375

Al376

Al377

Al378

Al379

Al380

Al381

Al382

Al383

Al384

Al385

Al386

Al387

Al388

Al389

Al390

Al391

Al392

Al393

Al394

Al395

Al396

Al397

Al398

Al399

Al 400 
4/,26X, ' INPUT IS REQUIRED. ' $/ /, 21 \mathrm{X}, '=1$, THE TEMPERATURE IS',

Al 401

$5^{\prime}$ CONSTANT DURING THE REACTION',/,26X,' STEPS AND DIFFERS FROM THAT 6 OF THE INITIAL SOL $-1 /, 26 \mathrm{X}$, 'UTION(S) . ONE VALUE IS READ IN THE', 7' TEMP INPUT. $1 / /, 21 \mathrm{X},{ }^{\prime}=2$, THE TEMPERATURE IS VARIED FROM T(O) TO' $8, ' \mathrm{~T}(\mathrm{~F})$ IN',/,26X, 'NSTEPS EQUAL INCREMENTS, DURING THE REACTION',/ 9,26X, 'STEPS.' $, / /, 21 \mathrm{X},{ }^{\prime}=3$, THE TEMPERATURE',

$\$ '$ OF EACH REACTION STEP IS SPEC-',/,26X, 'IFIED IN TEMP INPUT, IN' $\%$,' ORDER. NSTEPS VALUES',/,26X, 'ARE READ.',/,1X, 'FORMAT (II) ',//) GO TO 91

2080 WRITE $(1,2090)$ OPTION

2090 FORMAT $(/ 1 X, A l l, /, 13 X, ' \operatorname{IOPT}(5)=0$, THE PE FROM THE',

1' INITIAL SOLUTION IS HELD CON-',/,26X, 'STANT DURTNG ALL THE',

2' REACTION STEPS FOR THE', /,26X, 'SIMULATION. ' $/ /, 21 \mathrm{X}, '=1$, THE PE', 3 ' OF THE REACTION SOLUTION IS DETERMINED',/,26X, 'BY THE REACTION.' $4, /, 1 \mathrm{X}$, 'FORMAT (II) ',//)

GO TO 91

2100 WRITE $(1,2110)$ OPTION

2110 FORMAT $\left(/ 1 \mathrm{X}, \mathrm{Al} 1, /, 13 \mathrm{X},{ }^{\prime} \mathrm{IOPT}(6)=0\right.$, DEBYE-HUCKEL',

1' ACTIVITY COEFFICIENTS ARE USED FOR',/,26X, 'THE CALCULATIONS. (' Al419

2, 'SEE SPECIES INPUT) $, ' / /, 21 \mathrm{X}, '=1$, DAVIES ACTIVITY COEFFICIENTS', Al420

3' ARE USED. (SEE',/,26X, 'SPECIES INPUT) ',/,1X,'FORMAT (Il)',//) Al 421

GO TO 91

2120 WRITE $(1,2130)$ OPTION

2130 FORMAT $(/ 1 \mathrm{X}, \mathrm{All}, /, 13 \mathrm{X}, \operatorname{IOPT}(7)=0$, DO NOT SAVE THE',

I' AQUEOUS PHASE COMPOSITION AT' $/, 26 \mathrm{X}$, 'THE END OF A REACTION FOR',

2' ADDITIONAL SIMU-',/,26X, 'LATIONS. ', $/ /, 21 \mathrm{X}, '=1$, SAVE THE FINAL',

3' REACTION SOLUTION IN SOLUTION' ,/,26X, 'NUMBER $1.1, / /, 21 \mathrm{X}$, '= 2, ',

4' SAVE THE FINAL REACTION SOLUTION IN SOLUTION',/,26X, 'NUMBER 2.'

$5, /, 1 \mathrm{X}$, 'FORMAT (II) ',//)

GO TO 91

2140 WRITE $(1,2150)$ OPTION

2150 FORMAT $(/ 1 \mathrm{X}, \mathrm{Al} 1, /, 13 \mathrm{X}$, 'IOPT $(8)=0$, THE DEBUGGING PRINT'

$1, '$ ROUTINE IS NOT CALLED. ' $/ / / 21 \mathrm{x}, '=1$, A LONG PRINIOUT IS OUTPUT'

2,' AT EACH ITERATION IN',/,26X, 'EACH PROBLEM. THIS PRINT IS TO BE

3 USED ONLY',/,26X, 'IF THERE ARE CONVERGENCE PROBLEM WITH THE',

4/,26X, 'PROGRAM. (SEE SUBROUTINE PBUG) ',/,1X, 'FORMAT (II) ',//) GO TO 91

2160 WRITE $(1,2170)$ OPTION

2170 FORMAT $(/ 1 \mathrm{X}, \mathrm{All}, /, 13 \mathrm{X}, ' \operatorname{IOPT}(9)=0$, NO PRINTOUT OF EACH',

1' ARRAY INVERTED. ' $/ / /, 21 X, '=1$, A LONG PRINTOUT OCCURS OF THE',

2' ENTIRE ARRAY TO',/,26X, 'BE INVERTED AT EACH ITERATION. THIS',

3' PRINT IS',/,26X, 'USED ONLY IF THERE ARE CONVERGENCE PROBLEMS.',

$4 /, 26 \mathrm{X}$, ' (SEE SUBROUTINE SLNQ) ',/,1X, 'FORMAT (II) ',//)

GO TO 91

2200 WRITE $(1,2210)$ OPTION

2210 FORMAT $(/ 1 \mathrm{X}, \mathrm{All}, /, 13 \mathrm{X}$, 'NSTEPS' $7 \mathrm{X}$, 'THE NUMBER OF'

$1, '$ STEPS. A VALUE IS' $/, 26 \mathrm{X}$, 'REQUIRED IF IOPT(3) $=1,2,3,1$,

$2^{\prime} \mathrm{OR} 4$, OR IF', $/, 26 \mathrm{X},{ }^{\prime}$ IOPT(4) $=2$ OR $3.1, /, 1 \mathrm{X},{ }^{\prime}$ FORMAT $($ I2),$/ / /$ )

GO TO 250

2300 WRITE $(1,2310)$ OPTION

Al 402

Al 403

Al404

Al 405

Al 406

Al 407

Al 408

Al 409

Al410

Al411

Al 412

Al 413

Al414

Al415

Al416

Al 417

Al 418

Al 421

Al 423

Al424

Al 425

Al 426

Al 427

Al 428

Al 429

Al 430

Al431

Al 432

Al 433

Al 434

Al 435

Al 436

Al 437

Al 438

Al 439

Al 440

Al 441

Al 442

Al 443

Al 444

Al 445

Al 446

Al 447

Al 448

Al 449

Al 450 
2310 FORMAT (/1X,All,$/, 13 \mathrm{X}$, 'NCOMPS' $7 \mathrm{X}$, 'THE NUMBER OF CONSTIT',

Al451

1 'UENIS IN A NET STOICHIO-',/26X, 'MEIRIC REACTION. A CONSTITUENT M Al 452

2AY BE ANY', /,26X, ' ELEMENT WITH AN INDEX NUMBER BEIWEEN 4 AND',

$3 /, 26 \mathrm{X}$, ' 30 INCLUSIVE. NO AQUEOUS SPECIES WITH INDEX',/,26X, 'NUMBER

4S GREATER THAN 30 MAY BE INCLUDED AS', /,26x, 'REACTION CONSTITUENTS

5 EXCEPT H2 AND 02. ANY', /,26X, 'CONSTITUENT WITH AN INDEX NUMBER G 6REATER THAN',/,26X, '30 IS ASSUMED TO BE EITHER H2 OR O2 AND HAS',/ $7,26 \mathrm{X}$, 'THE EFFECT OF RAISING OR LOWERING THE REDOX', $/, 26 \mathrm{X}$, ' STATE OF 8 THE SOLUTION DEPENDING ON THE AS- $1, /, 26 \mathrm{X}$, 'SIGNED VALENCE (THMEAN)

9. A VALUE FOR NCOMPS', /,26X, 'IS REQUIRED IF IOPT(3) $=3,4$, OR 6 . ' ', $/, 1 \mathrm{X}$, ' FORMAT (I2) ', ///)

GO TO 301

2400 WRITE $(1,2410)$ OPTION

2410 FORMAT $\left(/ 1 \mathrm{X}, \mathrm{All}, /, 13 \mathrm{X}, \mathrm{V}^{\mathrm{V}} \mathrm{\prime}, 11 \mathrm{X}\right.$, 'THE INITIAL VOLUME OF SO',

1 'LUTION NUMBER 1 WHEN', $/ 26 \mathrm{X}$, 'MODELING A TITRATION. THIS UNIT OF $\mathrm{V}$

20 MUST',$/ 26 \mathrm{X}$, 'BE THE SAME AS THAT OF XSTEP (SEE STEPS INPUT) $1,1,2$

$36 \mathrm{X}, \mathrm{IF}^{\prime} \operatorname{IOPT}(3)=2$. OTHERWISE, VO IS NOT REQUIRED', $/, 1 \mathrm{X}$, 'FORMAT ( $4 \mathrm{~F} 10.5) ', / / /$

GO TO 430

4146 WRITE $(1,4147)$ SUB(1)

4147 FORMAT $(/ 1 \mathrm{X}, \mathrm{A8}, 10 \mathrm{X}$, 'THIS INPUT IS USED TO DEFINE A STARTING'

$1, '$ SOLU-', $/, 19 \mathrm{X}$, 'TION. ', $/ /$ )

GO TO 621

4148 WRITE $(1,4149)$ SUB $(2)$

4149 FORMAT $(/ 1 \mathrm{X}, \mathrm{A8}, 10 \mathrm{X}$, 'THIS INPUT DEFINES THE NAMES AND INDICES',

l' OF ALL',/,19X,' ELLEMENTS IN THE AQUEOUS MODEL DATA BASE.',//) GO TO 621

4150 WRITE $(1,4151)$ SUB(3)

4151 FORMAT (/1X,A8,10X, 'THIS INPUT DEFINES THE NAMES, INDEX NUMB'

1 'ERS AND', $/, 19 \mathrm{X},{ }^{\prime}$ COMPOSITION OF ALL AQUEOUS SPECIES IN THE',

2' AQUEOUS', $/, 19 \mathrm{X}$, 'MODEL DATA BASE. ', ///

GO TO 621

4152 WRITE $(1,4153)$ SUB $(4)$

4153 FORMAT $(/ 1 \mathrm{X}, \mathrm{AB}, 10 \mathrm{X}$, 'THIS INPUT DEFINES THE PHASES WHICH WILL'

$1, '$ BE MAIN-',/,19X, 'TAINED AT EQUIIIBRIUM WITH EACH OF THE'

2, ' REACTION',$/, 19 \mathrm{X}$, ' SOLUTIONS', ///)

GO TO 621

4154 WRITE $(1,4155)$ SUB $(5)$

4155 FORMAT (/1X,A8,10X,' THE PURPOSE OF THIS INPUT IS SIMPLY TO '

1, 'PROVIDE',$/, 19 \mathrm{X}$, ' INFORMATION ON THE SATURATION STATE OF THE'

$2, '$ AQUEOUS',$/, 19 \mathrm{X}$, ' PHASE WITH RESPECT TO DESIRED MINERALS. '

3, 'THE',$/, 19 \mathrm{X}$, 'MINERALS IN THIS BLOCK OF INPUT DO NOT AFFECT'

$4, '$ THE',$/, 19 \mathrm{X}$, 'CALCULATIONS OF THE INITIAL SOLUTION OR ANY '

$5, '$ OF THE',, $19 \mathrm{X}$, 'REACTION SOLUTIONS. THIS INPUT IS NEVER'

$6, '$ MANDATORY.',$/ / /$

GO TO 621

4156 WRITE $(1,4157)$ SUB $(6)$

4157 FORMAT $(/ 1 \mathrm{X}, \mathrm{AB}, 10 \mathrm{X}$, 'THIS INPUT VARIES THE TEMPERATURE DURING'

$1, '$ THE',$/, 19 \mathrm{X}$, ' REACTION STEPS. ',$/ / /$

GO TO 621

Al 453

Al 454

Al 455

Al 456

Al 457

Al458

Al 459

Al460

Al461

Al 462

Al463

Al464

Al 465

Al 466

Al 467

Al 468

Al 469

Al 470

Al 471

Al 472

Al 473

Al 474

Al 475

Al 476

Al 477

Al 478

Al 479

Al 480

Al 481

Al 482

Al 483

Al484

Al485

Al 486

Al487

Al 488

Al489

Al490

Al491

Al492

Al 493

Al494

Al 495

Al 496

Al 497

Al498

Al 499

Al500 
4158 WRITE $(1,4159)$ SUB (7)

Al501

4159 FORMAT $(/ 1 \mathrm{X}, \mathrm{A} 8,10 \mathrm{X}, 1 \mathrm{THIS}$ INPUT DEFINES THE STEPS OF THE '

Al502

$1, '$ REACTION PROCESS.' ,//)

Al503

GO TO 621

Al504

4160 WRTTE $(1,4161)$ SUB $(8)$

4161 FORMAT $(/ 1 \mathrm{X}, \mathrm{A} 8,10 \mathrm{X}$, 'THIS INPUT DESCRIBES THE STOICHIOMETRY'

$1, '$ AND VALENCE', $/, 19 \mathrm{X}$, ' OF THE ELEMENTS TO BE ADDED AS A'

$2, '$ REACTION.',$/ / /$ )

GO TO 621

4162 WRITE $(1,4163)$ SUB $(9)$

4163 FORMAT $(/ 1 \mathrm{X}, \mathrm{A8}, 10 \mathrm{X}, '$ 'THIS INPUT DEFINES THE ELEMENTS TO BE '

$1, '$ USED TO', $/, 19 \mathrm{X}$, 'ADUUST THE INITIAL SOLUTION(S) TO ELECTRI'

2, 'CAL', /, 19X, 'NEUTRALITY.' ,//)

GO TO 621

4164 WRITE $(1,4165)$ SUB $(10)$

4165 FORMAT $(/ 1 \mathrm{X}, \mathrm{A} 8,10 \mathrm{X}$, 'THIS INPUT SUMS MOLALITIES OF AQUEOUS'

$1, '$ SPECIES WHICH',/,19X, 'ARE THEN PRINIED IN THE OUTPUT OF THE'

$2, '$ RIN. THESE' ,/,19X, 'SUMS DO NOT AFFECT THE CALCULATIONS IN'

3 ,' ANY WAY AND',/,19X, 'ARE NEVER MANDATORY.' ,//)

GO TO 621

4166 WRITE $(1,4167)$ SUB $(11)$

4167 FORMAT $(/ 1 \mathrm{X}, \mathrm{A} 8,10 \mathrm{X}$, 'THIS CARD TERMINATES INPUT OPERATIONS'

$1, '$ FOR $A^{\prime}, /, 19 X, '$ 'SINGLE SIMULATION. ANY COMPUTER RUN HAS '

2, 'AT LEAST ONE',/,19X, 'END CARD.', ///)

GO TO 621

4200 WRITE $(1,4210)$

4210 FORMAT (/1X, 'POSSIBLE KEYWORDS: ' ///1X, ' (1) ELEMENIS, (2) SPECIES'

$1, '$, (3) SOLUTION, (4) MINERALS, (5) LOOK MIN, ',/,1X, ' (6) TEMP,

2,' (7) STEPS, (8) REACTION, (9) NEUTRAL, (10) SUMS, (11) END', //, IX

3, 'FORMAT (A8) ',$/ /, '$ ' FOR MORE INFORMATION ON ANY OF THE DATA'

$4, '$ BLOCK, ENTER THE',/,IX,'NUMBER ASSOCIATED WITH IT.',/) GO TO 621

1492 WRTTE $(1,1493)$ SUB $(1)$

1493 FORMAT $(/ 1 \mathrm{X}, \mathrm{A} 8, /, 13 \mathrm{X}$, ' $\mathrm{N}$ ', 12X, 'A NUMBER OF EITHER 1 OR 2 INDICAT'

1 ,'ING THE',/,26X,' SOLUTION NUMBER OF THE FOLLOWING DATA.',/,IX

2,'FORMAT (Il) $/ / /$ )

GO TO 1739

4300 WRITE $(1,4310)$ SUB $(1)$

4310 FORMAT $(/ 1 \mathrm{X}, \mathrm{A} 8, /, 13 \mathrm{X}$, 'HEAD',/,13X, 'FORMAT (A80),$/, 13 \mathrm{X}$,

1 'TITLE OR COMMENTS ABOUT THE SOLUTION.',//)

GO TO 1488

Al505

Al506

Al507

Al508

Al509

Al510

Al5ll

Al512

Al513

Al5l4

Al515

Al516

Al517

Al518

Al519

Al520

Al521

Al522

Al523

Al524

Al525

Al526

Al527

Al528

Al529

Al530

Al531

Al532

Al533

Al534

Al535

Al536

Al537

Al538

Al539

Al540

Al541

Al542

4320 WRTIE $(1,4330)$ SUB $(1)$

Al543

IS TO BE',/,26X, 'READ FROM CARD INPUT. FOR EXAMPLE, IF THE',/,26X,

2 ' STARTING SOLUTION IS MGCI,2-NAHCO3 SOLUTION' $/, 26 \mathrm{X}, '$ NIOTS $=4$ (FOR

3 MG, CL, NA, AND C) ',/,IX,'FORMAT (I2) ',//)

Al544

Al545

GO TO 1713

Al546

Al547

4340 WRITE $(1,4350)$ SUB $(1)$

Al548

4350 FORMAT $(/ 1 \mathrm{X}, \mathrm{A8}, /, 13 \mathrm{X}$, 'IALK',9X,'FLAG WHICH INDICATES WHETHER TOTAL Al549

1 CARBON OR',/,26X, 'TOTAL ALKALINITY IS TO BE INPUT.' $/ / /, 21 \mathrm{X},{ }^{\prime}=0$,

Al550 
2INDICATES THE TOTAL CONCENTRATION OF CARBON',/,26X,' (NOT ALKALINIT 3Y) IS INPUT IN THE UNITS',/,26X, 'SPECIFIED BY IUNITS.' $/ / /, 21 X^{\prime}=\mathrm{N}$ $4,4<=\mathrm{N}<=30$, WHERE $\mathrm{N}$ IS THE INDEX NUMBER FOR' /,26X, 'THE ELEMENT CA 5RBON, ( IN OUR DATA BASE $N=15$ ) ' $/, 26 \mathrm{X}$, ' INDICATES TOTAL ALKALINITY I 6S BEING ENTERED.',$/, 26 \mathrm{X}$, ' ELEMENTS INPUT MAY BE REQUIRED. THE UNIT 7S OF',/,26X, 'ALKALINITY ARE SPECIFIED BY IUNITS', $/, 26 X^{\prime}$ 'AND IF ', $9^{\prime}$ IUNITS $>0$, THE GRAM FORMULA WEIGHT (GFW) ',/,26X, 'OF THE ELEMENT' $!, '$ CARBON IS CRITICALLY IMPORTANT.',$/, 26 \mathrm{X}$, 'THE GFW IN THE CASE OF' @,' ALKALINITY MUST BE THE',/,26X, 'GRAM EQUIVALENT WEIGHT (GRAMS/EQ \#UIVALENT) OF',/,26X,'THE CHEMICAL SPECIES IN WHICH THE ALKALINTY', $\$ /, 26 \mathrm{X}$, ' IS REPORIED. THE FOLLOWING IS A LIST OF', $/ / /, 1$ HIT <RETURN (> FOR MORE EXPLANATION')

$\operatorname{READ}(1,1731)$ LINE

WRITE $(1,4355)$

4355 FORMAT(//26X, 'SPECIES ',

\% 'COMMONLY USED FOR REPORTING ALKA-',/,26X, 'LINITY AND THEIR CORRES 'PONDING EQUIVALENT',/,26X, 'WEIGHTS: ',//,31X, 'CACO3 ',4X, '50.0446 G/ $\& E Q^{\prime}, / /, 31 \mathrm{X},{ }^{\prime} \mathrm{HCO}-1,4 \mathrm{X},{ }^{\prime} 61.0171 \mathrm{G} / \mathrm{EQ}^{\prime}, / /, 31 \mathrm{X},{ }^{\prime} \mathrm{CO}-\mathrm{I}^{\prime}, 4 \mathrm{X}, 130.0046 \mathrm{G} /$ *EQ',//,26X, ' IN OUR DATA BASE 44.010 IS THE GFW OF CARBON' /,26X, 'W (HICH IS SUITABLE FOR ENTERING CARBON AS' /,26X,' TOTAL CO2. THIS G ) FW MUST BE CHANGED VIA', $/, 26 \mathrm{X}$, 'ELEMENTS INPUT IF ALKALINITY IS TO' -,' BE ENTERED',/,26X,'AS MG/L OR PPM (IUNITS = 2 OR 3). IF IUNITS $=1, /, 26 \mathrm{X}, 1=0$ ALKALINITY MUST BE INPUT AS EQ/KG H2O AND',/,26X, ' IN' ,$+ '$ THIS CASE THE GFW NEED NOT BE CHANGED SINCE' $/, 26 X^{\prime}$ 'NO CONVERSI :ON IS NECESSARY.' $/, 1 \mathrm{X}$, 'FORMAT (I3),$/ / /$ )

GO TO $(1714,1752)$, JUMP+1

Al551

Al552

Al553

Al554

Al555

Al556

Al557

Al558

Al559

Al 560

Al561

Al562

Al563

Al564

Al565

Al566

Al567

Al568

Al569

Al570

Al571

Al572

Al573

Al574

Al575

Al576

4360 WRITE $(1,4370)$ SUB $(1)$

Al577

Al578

IONCENTRATIONS. $1 /, 26 \mathrm{X}$, 'THE PROGRAM MAKES ALL OF ITS CALCULATIONS'

$2, /, 26 \mathrm{X}$, ' IN TERMS OF MOLALITY AND ANY OTHER ALLONED', $/, 26 \mathrm{X}$, 'CONCEN'

$3, '$ TRATION UNITS (MMOLES/L, MG/L,' ,/26X, 'OR PPM) MUST BE CONVERTED' 4,' TO MOLALITY',/26X, 'BEFORE THE CALCULATION MAY BEGIN. TO MAKE', 5/26X, 'THE CONVERSIONS IT IS NECESSARY TO KNOW THE',/26X, 'GRAM FORM 6ULA WEIGHT (GFW), IN G/MOLE, OF THE',/26X, 'CHEMICAL FORMULA IN WHI 7CH ELEMENTAL ANALYSES',/,26X, 'ARE REPORTED. THE GFW IS AN INPUT $P$ 8ARAMETER',/,26X, 'UNDER ELEMENTS INPUT AND MUST BE IN AGREEMENT',

Al579

Al580

Al581

Al582

Al583

Al584

Al585

9/,26X,'WITH THE ANALYTICAL UNITS FOR EACH SOLUTION',/,26X,'DATA SE

!T. (IF THE UNITS ARE MOLALITY, NO',/,26X, 'CONVERSION IS NECESSARY

(a AND THE GFWS ARE NOT',/,26X,'USED.) NOTE: ALL ELEMENTS MUST HAV \#E',$/, 26 \mathrm{X}$, 'THE SAME UNITS. IT IS NOT POSSIBLE TO ENTER $\mathrm{MG} / \mathrm{L}^{\prime}, /, 26 \mathrm{X}$ $\$$, 'OF ONE ELEMENT AND MOLALITY OF ANOTHER. ' $/ / /$, ' HIT 〈RETURN> FOR' /,' MORE EXPLANATION')

Al586

Al587

Al588

Al589

Al590

Al591

Al592

READ $(1,1731)$ LINE

WRITE $(1,4375)$

Al593

Al594

Al595

4375 FORMAT $(/ 21 \mathrm{X}, '=0$, CONCENTRATION ',

\% 'OF ELEMENTS ENTERED AS MOLALITY',/,26X, 'OF EACH ELEMENT, OR FO','

${ }^{\circ} \mathrm{R}$ ALKALINITY, EQUIV-' $/ / 26 \mathrm{X},{ }^{\prime}$ ALENIS/KG H2O. $, 1 / /, 21 \mathrm{X},{ }^{\prime}=1$, CONCENIR \&ATION OF ELEMENTS ENTERED AS MMOLES/L',/,26X, 'OF EACH ELEMENT, OR' *,' FOR ALKALINITY, MEQ/L.' $, / /, 21 \mathrm{X},{ }^{\prime}=2$, CONCENTRATION OF ELEMENTS (ENTERED AS MG/L',/,26X, 'OF THE SPECIES WHICH HAS A GRAM FORMULA', 
//,26X, 'WEIGHT GIVEN IN ELEMENTS INPUT. (ELEMENIS',/,26X, 'INPUT MA -Y BE REQUIRED.) ' $, / /, 21 \mathrm{X},{ }^{\prime}=3$, CONCENTRATION OF ELEMENTS ENTERED AS $=$ PPM',$/, 26 \mathrm{X}$, 'OF THE SPECIES WHICH HAS A GRAM FORMULA',,$/, 26 \mathrm{X}$, 'WEIGH +T GIVEN IN ELLEMENIS INPUT. (ELEMENTS', /,26X, ' INPUT MAY BE REQUIRE :D.) ', /, IX, 'FORMAT (II) ',//)

GO TO 1715

IR ALL' ',/,26X, ' SOLUTIONS. ', /,1X, ' FORMAT (F10.3) ',//) GO TO 1723

4420 WRITE $(1,4430)$ SUB $(1)$

4430 FORMAT $(/ 1 \mathrm{X}, \mathrm{A8}, /, 13 \mathrm{X}$, 'TEMP', $9 \mathrm{X}$, 'THE TEMPERATURE OF THE SOLUTION IN

1 DEGREES', $/, 26 \mathrm{X}$, 'CELCIUS. ',$/, 1 \mathrm{X}$, ' FORMAT (F10.3) $1, / /$ ) GO TO 1724

4440 WRITE $(1,4450)$ SUB $(1)$

Al614

Al615

Al616

Al617

Al618

Al619

4450 FORMAT $\left(/ 1 \mathrm{X}, \mathrm{A} 8, /, 13 \mathrm{X}, \mathrm{SDENS}^{\prime}, 8 \mathrm{X}, \mathrm{ITHE}^{\mathrm{T}} \mathrm{DENSITY}\right.$ OF THE SOLUTION. $1, /, 1$

IX, ' FORMAT (F10.3)',//)

GO TO 1482

4100 WRITE $(1,4101)$ SUB $(1)$

4101 FORMAT $(/ 1 \mathrm{X}, \mathrm{AB}, /, 13 \mathrm{X}$, 'LT, DTOT', $6 \mathrm{X}$, 'TOTAL CONCENTRATIONS OF ELEMENT

1S. ',$/, 26 \mathrm{X}$, 'LT', $8 \mathrm{X}$, ' INDEX NUMBER OF THE ELEMENT. ',$/ /, 26 \mathrm{X}$, ' DTOT',

$26 \mathrm{X}$, 'TOTAL CONCENTRATION OF THE ELEMENT IN',$/, 36 \mathrm{X}$, 'MOLALITY, MMOLES

$3 / \mathrm{L}, \mathrm{MG} / \mathrm{L}, \mathrm{OR}$ ',$/, 36 \mathrm{X}$, ' PPM ACCORDING TO IUNITS. ',/,1X, 'FORMAT (I4'

$\left.4, ', 1 \mathrm{X}, \mathrm{F} 11.4)^{\prime}\right)$

WRITE $(1,4000)$

GO TO $(1326,1356)$, N2

4102 WRITE $(1,4103)$ SUB $(2)$

4103 FORMAT $(/ 1 \mathrm{X}, \mathrm{AB}, /, 13 \mathrm{X}$, 'TNAME', $8 \mathrm{X}$, 'ALPHANUMERIC NAME OF ELEMENT.',

$1 /, 1 \mathrm{X}$, ' FORMAT (A8) ')

WRITE $(1,4000)$

4000 FORMAT (' NOTE: FOR A LISTING OF MASTER SPECIES AND ELEMENTS,'

$1, /, 8 \mathrm{X}$, 'ENTER LIST>.',$/ / /$ )

GO TO 1729

4104 WRITE $(1,4105)$ SUB (2)

4105 FORMAT (/1X,A8,/,13X, 'NELT', 9X, ' INDEX NUMBER ASSIGNED TO THE ELEME

1NT. NUMBER',$/, 26 \mathrm{X}$, 'MUST BE BEIWEEN 4 AND 30, INCLUSIVE. ',/,1X,

2 ' FORMAT (I2) ')

WRITE $(1,4000)$

GO TO 1550

4106 WRITE $(1,4107)$ SUB $(2)$

4107 FORMAT ( $/ 1 \mathrm{X}, \mathrm{AB}, /, 13 \mathrm{X}$, ' TGFW', $9 \mathrm{X}$, ' 'GRAM FORMULA WEIGHT OF THE SPECIES

1 USED TO', $/, 26 \mathrm{X},{ }^{\prime}$ REPORT THE ANALYTICAL DATA. IF SOLUTION DATA'

$2, /, 26 \mathrm{X}$, ' IS TO INCLUDE ALKALINITY, TGFW FOR THE ELEMENT', $/, 26 \mathrm{X}$, 'CAR

3BON MUST BE THE EQUIVALENT WEIGHT OF THE',$/, 26 \mathrm{X}$, 'REPORTED ALKALINI 4 TY SPECIES.',$/, 1 \mathrm{X}$, ' FORMAT (F10.4)')

WRITE $(1,4000)$

Al620

Al621

Al622

Al623

Al624

Al 625

Al626

Al627

Al628

Al629

Al630

Al631

Al632

Al633

Al634

Al635

Al636

Al637

Al638

Al639

Al640

Al641

Al642

Al643

Al644

Al645

Al646

Al647

Al 648

Al649

Al650 
4111 FORMAT $\left(/ 1 \mathrm{X}, \mathrm{A} 8, /, 13 \mathrm{X}, \mathrm{I}^{\prime}, 12 \mathrm{X}\right.$, 'THE INDEX NUMBER ASSIGNED TO THE AQU Al653

IEOUS',/,26X, 'SPECIES. NUMBER 4 THROUGH 30 ARE RESERVED' ,/,26X,

2 'FOR MASTER SPECIES, 250 IS THE MAXIMUM INDEX',/,26X,'NUMBER FOR

3AN AQUEOUS SPECIES.' $/ /, 1 \mathrm{X}$, 'FORMAT (I3)' $/ / /$ )

GO TO 1590

Al654

Al655

Al656

A1657

4112 WRITE $(1,4113)$ SUB (3)

Al658

4113 FORMAT $(/ 1 \mathrm{X}, \mathrm{A8}, /, 13 \mathrm{X}$, 'SNAME' ,8X, 'ALPHANUMERIC SPECIES NAME.' ,/,IX, 1 'FORMAT (A8)', $/ / /$ )

GO TO 1660

Al659

A1660

Al661

4114 WRITE $(1,4115)$ SUB (3)

Al662

4115 FORMAT $(/ 1 \mathrm{X}, \mathrm{A} 8, /, 13 \mathrm{X}$, 'NSP',10X,'THE TOTAL NUMBER OF MASTER SPECIES

1 IN THE' $/, 26 \mathrm{X}$, 'ASSOCIATION REACTION THAT FORMS THIS SPECIES;,$/, 2$

$26 \mathrm{X}$, 'DO NOT COUNT THE SPECIES ITSELF UNLESS THE', $/, 26 \mathrm{X}$, 'SPECIES IS

3A MASTER SPECIES.' $/, 1 \mathrm{X}$, 'FORMAT (I3) ',//)

GO TO 1676

4116 WRITE $(1,4117)$ SUB(3)

Al663

Al664

Al665

Al666

A1667

4117 FORMAT $\left(/ 1 \mathrm{X}, \mathrm{A} 8 /, 13 \mathrm{X}, \mathrm{KFLAG}^{\prime}, 3 \mathrm{X},{ }^{\prime}=0\right.$, THE VAN' ' $\mathrm{T}$ HOFF EXPRESSION IS

1 USED TO CALOU-',$/, 26 \mathrm{X}$, 'LATE TEMPERATURE DEPENDENCE OF THE ASSOCIA

2TION',$/, 26 \mathrm{X}$, 'CONSTANT FOR THIS SPECIES. ' $/ /, 21 \mathrm{X}, '=1$, AN ANALYTICA

3L EXPRESSION IS USED TO CALCU-', $/, 26 \mathrm{X}$, 'LATE TEMPERATURE DEPENDENCE

4 OF THE ASSOCIATION' //,26X, 'CONSTANT. ' /, IX, 'FORMAT (II) ',//)

GO TO 1680

4118 WRITE $(1,4119)$ SUB (3)

Al668

Al669

Al670

Al671

Al672

Al673

Al674

Al675

4119 FORMAT $\left(/ 1 \mathrm{X}, \mathrm{A} 8, /, 13 \mathrm{X},{ }^{\prime} \mathrm{GFLAG}, 3 \mathrm{X}, '=0\right.$, THE EXTENDED DEBYE-HUCKEL OR

1 DAVIS EXPRES-',$/, 26 \mathrm{X}$, 'SION (ACCORDING TO IOPT(6)) IS USED TO CALC

2ULATE',/,26X, 'THE ACTIVITY COEFFICIENT FOR THIS SPECIES.' $/ / /, 21 \mathrm{X}$,

$3^{\prime}=1$, THE WATEQ DEBYE-HUCKEL EXPRESSION IS USED', $/, 26 \mathrm{X},{ }^{\prime}$ TO CALCULA

4TE THE ACTIVITY COEFFICIENT OF THIS',/,26X, 'SPECIES REGARDLESS OF

5THE VALUE OF IOPT(6),$/, 1 \mathrm{X}$, 'FORMAT (II),$/ / /$ )

GO TO 1690

Al676

Al677

Al678

Al679

Al680

Al681

Al682

4120 WRITE $(1,4121)$ SUB (3)

Al683

4121 FORMAT $(/ 1 \mathrm{X}, \mathrm{A} 8, /, 13 \mathrm{X}, ' \mathrm{ZSP}$, , $10 \mathrm{X}$, 'THE CHARGE ON THIS AQUEOUS SPECIES

$1 . ', / 1 \mathrm{X}$, 'FORMAT $\left.(\mathrm{F} 10.3)^{\prime}, / /\right)$

Al684

Al685

GO TO 1780

Al686

Al687

4122 WRITE $(1,4123)$ SUB (3)

Al688

IHE REDOX' $/, 26 \mathrm{X}$, 'SPECIES IN THIS SPECIES. (E.G. FESO4 HAS' $/, 26 \mathrm{X}$,

$2 ' A$ THSP $=2+6=8.)^{\prime}, /, 1 X,{ }^{\prime}$ FORMAT $(F 10.3)^{\prime}, / / /$

GO TO 1790

Al689

Al690

Al691

Al692

4124 WRITE $(1,4125)$ SUB(3)

Al693

Al694

$1.1,1,1 \mathrm{X}$, 'FORMAT $(\mathrm{F} 10.3) 1 / /)$

Al695

GO TO 1880

Al696

4126 WRITE $(1,4127)$ SUB $(3)$

Al697

4127 FORMAT $(/ 1 \mathrm{X}, \mathrm{A8}, /, 13 \mathrm{X}$, 'ADHSP(1) ',5X,'THE A(I) TERM FOR THE WATEQ DE IBYE-HUCKEL EXPRESSION.' //,IX,'FORMAT (F10.3) ',//)

GO TO 1892

Al698

Al699

4128 WRITE $(1,4129)$ SUB (3)

Al700 
4129 FORMAT $\left(/ 1 \mathrm{X}, \mathrm{A} 8, /, 13 \mathrm{X},{ }^{\prime}\right.$ ADHSP(2)',5X,' THE B(I) TERM FOR THE WATEQ DE Al701 IBYE-HUCKEL EXPRESSION.' $/, 1 \mathrm{X}$, 'FORMAT (F10.3) ',//) GO TO 1892

4130 WRITE $(1,4131)$ SUB (3)

Al702

Al703

Al704

4131 FORMAT $\left(/ 1 \mathrm{X}, \mathrm{A8}, /, 13 \mathrm{X},{ }^{\prime}\right.$ ALKSP', $8 \mathrm{X}$, 'THE ALKALINITY ASSIGNED TO THIS A Al705 IQUEOUS SPECIES.' $/, 1 \mathrm{X}$, 'FORMAT (F10.3)',//) GO TO 1740

4132 WRITE $(1,4133)$ SUB (3)

Al706

Al707

Al708

4133 FORMAT (/1X,A8,/,13X, 'LKTOSP',7X, 'LOG (K) AT 25 DEGREES CELCIUS', $I^{\prime}$, WHERE', $/$ )

WRITE $(1,4134)$

4134 FORMAT $\left(26 X_{1}^{\prime}\right.$ LOG $\left.(K)=A l+A 2 * T+A 3 / T+A 4 * T^{\wedge} 2+A 5 / T^{\wedge} 2{ }^{\prime}\right)$

Al709

Al710

Al711

WRITE $(1,4135)$

4135 FORMAT (/1X, 'FORMAT (F10.3) $/ /)$

Al712

Al713

GO TO 1960

4136 WRITE $(1,4137)$ SUB (3)

Al714

Al715

Al716

4137 FORMAT $(/ 1 \mathrm{X}, \mathrm{A8}, /, 13 \mathrm{X}$, 'DHSP' ,9X, 'STANDARD ENTHALPY OF THE ASSOCIAT' 1,' ION REACTION AT',/,26X,'25 DEGREES CELCIUS ( H(R), IN KCAL/'

2, 'MOLE ) $. ', /, 1 \mathrm{X}$, 'FORMAT (F10.3)',//) GO TO 1970

4138 WRITE $(1,4139)$ SUB $(3), K, K$

4139 FORMAT $(/ 1 \mathrm{X}, \mathrm{A8}, /, 13 \mathrm{X}$, 'ASP(',Il,' $)$ ',7X, 'A', Il, ' OF THE FOLLOWING', I' EQUATION: ',/)

WRITE $(1,4134)$

WRITE $(1,4140)$

4140 FORMAT (/1X,'FORMAT (F12.5)')

GO TO 1987

Al717

Al718

Al719

Al720

Al721

Al722

Al723

Al724

Al725

Al726

Al727

4142 WRITE $(1,4143)$ SUB (3)

4143 FORMAT $\left(/ 1 \mathrm{X}, \mathrm{A8}, /, 13 \mathrm{X}, \mathrm{ISS}^{\prime}, 10 \mathrm{X}\right.$, 'INDEX NUMBER OF MASTER SPECIES.'

$1, /, 1 X,{ }^{\prime}$ FORMAT (I3)')

WRITE $(1,4000)$

GO TO 1915

4144 WRITE $(1,4145)$ SUB (3)

4145 FORMAT $(/ 1 \mathrm{X}, \mathrm{A8}, /, 13 \mathrm{X}$, 'CSP' ,10X, 'STOICHIOMEIRIC COEFFICIENT OF',

1 ' MASTER SPECIES',/,26X, 'IN THIS AQUEOUS SPECIES.',/,IX, 'FORMAT'

$\left.2, '(F 7.3)^{\prime \prime}\right)$

WRITE $(1,4000)$

GO TO 1915

8000 WRITE $(1,8001)$ SUB (I)

8001 FORMAT $(/ 1 \mathrm{X}, \mathrm{A} 8, /, 13 \mathrm{X}$, 'MNAME' ,8X, 'ALPHANUMERIC NAME OF MINERAL' $/$, IIX, 'FORMAT (A8) ', ///)

GO TO 3102

8002 WRITE $(1,8003)$ SUB(I)

Al728

Al729

Al730

Al731

Al732

Al733

Al734

Al735

Al736

Al737

Al738

Al739

Al740

Al741

Al742

Al743

8003 FORMAT $\left(/ 1 \mathrm{X}, \mathrm{A} 8, /, 13 \mathrm{X},{ }^{\prime} \mathrm{NMINO}, 8 \mathrm{X}\right.$, 'NUMBER OF DIFFERENT SPECIES IN TH IE MINERAL', , ,26X, 'DISSOCIATION REACTION (INCLUDING H+, E-, AND', / $\left.2,26 \mathrm{X},{ }^{\prime} \mathrm{H} 2 \mathrm{O}\right)$. NMINO MUST BE LESS THAN OR EQUAL TO $10.1,1,1 \mathrm{X}$,

Al744

Al745

Al746

3 'FORMAT (I2)',///)

GO TO 3110

Al747

Al748

8004 WRITE $(1,8005)$ SUB (I)

Al749

8005 FORMAT $(/ 1 \mathrm{X}, \mathrm{A8}, /, 13 \mathrm{X}$, 'THMIN', $8 \mathrm{X}$, 'THE SUM OF THE VALENCES OF THE RE

Al750 
IDOX SPECIES' $, /, 26 \mathrm{X},{ }^{\prime}$ IN THE MINERAL DISSOCIATION REACTION. ' $/, 1 \mathrm{X}$, 2 'FORMAT (F10.3)',//)

GO TO 3120

8006 WRITE $(1,8007)$ SUB ( I)

8007 FORMAT ( $/ 1 \mathrm{X}, \mathrm{AB}, /, 13 \mathrm{X}$, 'LKTOM', $8 \mathrm{X}$, 'LOG OF THE EQUILIBRIUM CONSTANT'

$1, '$ AT 25 DEGREES', $/, 26 \mathrm{X}$, 'CELCIUS FOR THE REACTION', /,1X, 'FORM AT'

$\left.2, '(\mathrm{~F} 10.3)^{\prime}, / / /\right)$

GO TO 3130

8008 WRITE $(1,8009)$ SUB $(I)$

8009 FORMAT ( $1 \mathrm{X}, \mathrm{A} 8, /, 13 \mathrm{X},{ }^{2} \mathrm{DHMIN} ', 8 \mathrm{X}$, 'DELTA H(R) (KCAL/MOLE) FOR THE '

1 , 'VANT HOFF',$/, 26 \mathrm{X}$, ' EXPRESSION. ' $/, 1 \mathrm{X}$, ' FORMAT (F10.3) $1 / /$ )

GO TO 3140

8010 WRITE $(1,8011)$ SUB(I)

8011 FORMAT $\left(/ 1 \mathrm{X}, \mathrm{A} 8, /, 13 \mathrm{X},{ }^{\prime M F L A G}, 3 \mathrm{X},{ }^{\prime}=0\right.$, THE VANT HOFF EXPRESSION IS'

$1, '$ USED TO CALCU- $1, /, 26 \mathrm{X}$, 'LATE THE TEMPERATURE DEPENDENCE OF THE',

2' EQUIL $-1, / 26 \mathrm{X}$, ' IBRIUM CONSTANT', $/ /, 21 \mathrm{X},{ }^{\prime}=1$, THE ANALYTICAL EXP'

$3, '$ RESSION IS USED TO CALCU- $1 / 26 \mathrm{X}$, ' LATE THE TEMPERATURE DEPENDENCE

4 OF THE EQUIL-',$/, 26 \mathrm{X}$, ' IBRIUM CONSTANT. ' $/, 1 \mathrm{X}$, ' FORMAT (II) $1 / /)$

GO TO 3150

8012 WRITE $(1,8013)$ SUB(I)

8013 FORMAT (/1X,A8,/,13X, 'SIMIN' , 8X, 'SATURATION INDEX (LOG(ION ACTIVI' 1$, 'TY PRODUCT/K(SP) $)$ ),$/, 26 \mathrm{X}$, 'DESIRED IN THE FINAL SOLUTION. SIMIN $2=0.01, /, 26 \mathrm{X}$, 'WOULD PRODUCE EQUILIBRIUM WITH THE MINERAL', $/, 26 \mathrm{X}$,

3 'WHILE 1.0 WOULD PRODUCE A SOLUTION 10 TIMES',$/, 26 \mathrm{X}$, 'SUPERSATURATE 4D $($ SI $=1.0)$. THIS VARIABLE IS', $/, 26 \mathrm{X}$, 'USEFUL IN SPECIFYING THE ' 5, ' PARTIAL PRESSURE OF',$/, 26 \mathrm{X}$, 'A GAS. THE HENRY(S) LAW CONSTANT ', 6 'FOR THE GAS', $/, 26 \mathrm{X}$, 'WOULD BE ENTERED USING THE VANT HOFF (LKTOM)

$7 \%, 26 \mathrm{X},{ }^{\prime}$ OR ANALYTICAL EXPRESSION (AMIN) AND THE LOG OF' $/, 25 \mathrm{X}, '$ THE

8 PARTIAL PRESSURE WOLLD BE ENTERED FOR SIMIN.', /,1X, 'FORMAT (F10.3

9) $1, / / /)$

GO TO 3167

8014 WRITE $(1,8015)$ SUB(I)

8015 FORMAT (/1X, A8,/,13X, 'LMIN' , 9X, ' INDEX NUMBER OF SPECIES (NOT NECE'

1, 'SSARILY MASTER',$/, 26 \mathrm{X}$, ' SPECIES) IN THE DISSOCIATION REACTION ',

2 'FOR',$/, 26 \mathrm{X}$, 'THIS MINERAL', $/, 1 \mathrm{X}$, 'FORMAT (I4) ')

WRITE $(1,3800)$

GO TO 3195

8016 WRITE $(1,8017)$ SUB (I)

8017 FORMAT (/1X,A8,/,13X, 'CMIN' ,9X, 'STOICHIOMETRIC COEFFICIENT OF ',

l'SPECIES IN',/,26X, 'DISSOCIATION REACTION.',/,lX,' FORMAT (Fll.3)') WRITE $(1,3800)$

GO TO 3195

8018 WRITE $(1,8019)$ SUB $(I), K, K$

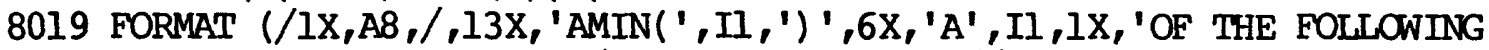

1 MINERAL DISSOCIATION', /,26X, 'REACTION: ' $/ / /, 26 \mathrm{X}$, 'LOG $(\mathrm{K})=\mathrm{Al}+$ '

$2,{ }^{\prime} \mathrm{A} 2 * \mathrm{~T}+\mathrm{A} 3 / \mathrm{T}+\mathrm{A} 4 \mathrm{~T}^{\wedge} 2+\mathrm{A} 5 / \mathrm{T}^{\wedge} 2 ', / /, 26 \mathrm{X}$, 'WHERE T IS IN DEGREES',

3' KELVIN',$/, 1 \mathrm{X}$, ' FORMAT (F12.5)',$/ /$ )

GO TO 3207

8020 WRITE $(1,8021)$ SUB $(6)$

8021 FORMAT (/1X,A8,/,13X, 'XTEMP' ,8X, 'TEMPERATURE IN DEGREES CELSIUS.'

Al751

Al752

Al753

Al754

Al755

Al756

Al757

Al758

Al759

Al760

Al761

Al762

Al763

Al764

Al765

Al766

Al767

Al768

Al769

Al770

Al771

Al772

Al773

Al774

Al775

Al776

Al777

Al778

Al779

Al780

Al781

Al782

Al783

Al784

Al785

Al786

Al787

Al788

Al789

Al790

Al791

Al792

Al793

Al794

Al795

Al796

Al797

Al798

Al799

Al 800 
$1, /, 1 \mathrm{X}$, 'FORMAT (F10.3) ',//)

Al 801

GO TO 3307

Al 802

8022 WRITE $(1,8023)$ SUB (7)

8023 FORMAT $(/ 1 \mathrm{X}, \mathrm{AB}, /, 13 \mathrm{X}, \mathrm{XSTEP}, \mathrm{XX}$, 'THE FRACTION OF SOLUTION 1 TO BE' $1, /, 26 \mathrm{X}$, 'MIXED WITH SOLUTION 2.1 )

Al 803

Al 804

Al 805

Al 806

8030 WRITE $(1,8029)$

8029 FORMAT (IX,'FORMAT (F10.9)',//)

Al 807

GO TO 3607

Al 808

8024 WRITE $(1,8025)$ SUB (7)

8025 FORMAT ( $/ 1 \mathrm{X}, \mathrm{AB}, /, 13 \mathrm{X}$, 'XSTEP' , $8 \mathrm{X}$, ' 'THE VOLUME OF SOLUTION 2 TO',

1' BE',$/, 26 \mathrm{X}$, 'TITRATED INTO SOLUTION 1. XSTEP MUST', /,26X, ' HAVE'

$2, '$ THE SAME UNITS AS VO.')

GO TO 8030

8026 WRITE $(1,8027)$ SUB (7)

8027 FORMAT $\left(/ 1 \mathrm{X}, \mathrm{AB}, /, 13 \mathrm{X}, \mathrm{XSSTEP}^{\prime}, 8 \mathrm{X}\right.$, 'THE MOLES OF REACTION TO BE',

l'ADDED', $/, 26 \mathrm{X}$, 'TO SOLUTION 1 ')

GO TO 8030

8028 WRITE $(1,8031)$ SUB $(7)$

8031 FORMAT $(/ 1 \mathrm{X}, \mathrm{A} 8, /, 13 \mathrm{X}$, 'XSTEP', $8 \mathrm{X}$, 'THE TOTAL NUMBER OF MOLES OF'

$1, /, 26 \mathrm{X}$, 'REACTION TO BE ADDED IN NSTEPS', /,26X, 'STEPS. NSTEPS'

$2, '$ REACTION SOLUTIONS'/,26X, 'WILL BE CALCULATED. THE I(TH) SOLU-'

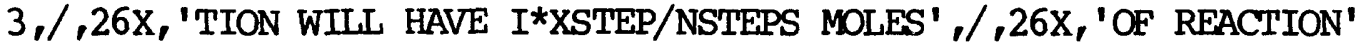

$4, '$ ADDED TO SOLUTION $1 . '$ ')

GO TO 8030

8032 WRITE $(1,8033)$ SUB $(8)$

8033 FORMAT ( $/ 1 \mathrm{X}, \mathrm{A8}, /, 13 \mathrm{X}$, 'LREAC', $8 \mathrm{X}$, ' INDEX NUMBER OF ELEMENT FOR THE' $1, '$ REACTION.' ', $/, 26 \mathrm{X}$, 'LREAC MUST BE BEIWEEN 4 AND 30 INCLUSIVE. ',$/$, $226 \mathrm{X}$, ' IF LREAC IS GREATER THAN 30 THE PROGRAM', /,26X, 'CONSIDERS',

3' THIS CONSTITUENT TO BE H2 OR ',$/, 26 \mathrm{X}$, 'O2 AND ONLY USES CREAC',

4 ' AND THMEAN', $/, 26 \mathrm{X},{ }^{\prime}$ TO CHANGE THE OXIDATION STATE OF THE',$/, 26 \mathrm{X}$

5, 'REACTION SOLUTION.' ,/,1X, 'FORMAT (I4)')

WRITE $(1,3800)$

GO TO 5015

8034 WRITE $(1,8035)$ SUB (8)

8035 FORMAT (/1X, A8,/,13X, 'CREAC' $8 \mathrm{X}$, ' STOICHIOMETRIC COEFFICIENT OF'

$1, '$ THE ELEMENT',$/, 26 \mathrm{X}$, ' IN THE REACTION',/,1X, 'FORMAT (F8.3)')

WRITE $(1,3800)$

GO TO 5015

8036 WRITE $(1,8037)$ SUB $(8)$

8037 FORMAT $(/ 1 \mathrm{X}, \mathrm{A8}, /, 13 \mathrm{X}$, 'THMEAN', $7 \mathrm{X}$, 'THE VALENCE OF THE ELEMENT IN'

$1, '$ THE REACTION. $1, / 26 \mathrm{X},{ }^{\prime}$ AN ELEMENT MAY BE INCLUDED MORE THAN',

2 ' ONCE IN', $26 \mathrm{X}$, 'A REACTION TO ACCOMODATE DIFFERENT VALENCE',$\%$

$326 \mathrm{X}$, 'STATES OF THE ELEMENT.',$/, 1 \mathrm{X}$, 'FORMAT (F8.3)')

WRITE $(1,3800)$

GO TO 5015

8038 WRITE $(1,8039)$ SUB $(9)$

8039 FORMAT ( $/ 1 X, A 8, /, 13 X_{1}$, 'LPOS' $9 \mathrm{X}$, ' INDEX NUMBER OF AN ELEMENT WITH'

1, ' A CATION',$/, 26 \mathrm{x}$, 'MASTER SPECIES. ',$/, 1 \mathrm{X}$, ' FORMAT (I5) ')

WRITE $(1,3800)$

GO TO 6010

Al 809

Al 810

Al811

Al 812

Al 813

Al 814

Al 815

Al 816

Al 817

Al 818

Al 819

Al 820

Al 821

Al 822

Al 823

Al 824

Al 825

Al 826

Al 827

Al 828

Al 829

Al 830

Al 831

Al 832

Al 833

A1834

Al 835

Al 836

Al 837

Al 838

Al 839

Al 840

Al 841

Al 842

Al 843

Al 844

Al 845

A1846

Al 847

Al 848

Al 849

Al 850 
8040 WRITE $(1,8041)$ SUB (9)

Al 851

8041 FORMAT (/1X,A8,/,13X, 'LNEG',9X, ' INDEX NUMBER OF AN ELEMENT WITH'

$1, '$ AN ANION',/,26X, 'MASTER SPECIES.' ,/,1X, 'FORMAT (I5)')

WRITE $(1,3800)$

3800 FORMAT (1X,' NOTE: FOR A LISTTING OF MASTER SPECIES AND ELEMENTS,'

$1, /, 8 X_{1}$, ENTER 〈LIST>.',$/ / /$

GO TO 6020

8042 WRITE $(1,8043)$ SUB $(10)$

8043 FORMAT (/1X,A8,/,13X, 'SUNAME' ,7X, 'ALPHANUMERIC NAME TO BE PRINT'

1 'ED TO IDENTIFY',/,26X, 'THE SUM.',/,1X, 'FORMAT (A8) '//)

GO TO 7010

8044 WRITE $(1,8045)$ SUB $(10)$

8045 FORMAT $(/ 1 \mathrm{X}, \mathrm{A} 8, /, 13 \mathrm{X}$, 'NSUM' ,9X, 'THE NUMBER OF INDEX NUMBER TO BE'

$1, '$ READ.' $/, 26 \mathrm{X}$, 'NSUM $<=50.1, /, 1 \mathrm{X}$, 'FORMAT (I2) $1 / /$ )

GO TO 7020

8046 WRITE $(1,8047)$ SUB (10)

8047 FORMAT $(/ 1 \mathrm{X}, \mathrm{A} 8, /, 13 \mathrm{X}$, 'LSUM' $9 \mathrm{X}$, ' INDEX NUMBERS OF SPECIES IN '

$1, '$ 'SUM. ' $/, 1 \mathrm{X}$, 'FORMAT (I4) $1 / /$ )

GO TO 7037

END

SUBROUTINE READFILE

C

C

THIS SUBROUTINE READS FROM LOGICAL FILE \#II,

PRE-CONSTRUCTED MINERAL CARDS; AND FROM LOGICAL FILE \#12,

THE THERMODYNAMIC DATA OF PHREEQE, THE NECESSARY INFORMATIONS

TO CONSTRUCT A MASTER SPECIES AND ELEMENTS TABLE.

REAL ICOL $3(0: 30)$,NOUSE6

CHARACTER *80 LINE

CHARACTER *12 THMIN(100), LKTTOM(100),DHMIN(100), $\operatorname{SIMIN(100)~}$

$1, \operatorname{CMIN}(100,10), \operatorname{AMIN}(100,5)$

CHARACTER *8 NONE, MNAME (100), SUB(11), ICOLl $(0: 30), \operatorname{ICOL} 4(0: 30)$

$1, \operatorname{SPEC}(30)$, KEYWORD, NOUSE2

COMMON /PT/ MNAME, NMINO (100), THMIN, LKTOM,DHMIN, MFLAG (100)

1, SIMIN, LMIN $(100,10), C M I N$, AMIN, IMINERAL, SUB, ICOLI, ICOL $2(0: 30)$

2, ICOL 3 , ICOL 4 , SPEC, OPV (30)

$\mathrm{C}$ DATA NONE/ $1 * * * * * * * * 1 /$

Al852

Al 853

Al854

Al 855

Al 856

Al 857

Al 858

Al 859

Al 860

Al861

Al862

Al 863

Al864

Al865

Al 866

Al 867

Al 868

Al869

Al 870

B 1

B 2

B 3

B 4

B 5

B 6

B 7

B 8

B 9

B 10

B 11

B 12

B 13

B 14

B 15

B 16

B 17

B 18

LREAD $=0$

DO $40 \quad M=1,30$

B 19

B 20

$40 \operatorname{ICOL} 2(M)=0$

NUM $=1$

B 21

B 22

C

READ MINERAL CARDS.

B 23

B 24

NOTE: MAXIMUM NUMBER OF MINERALS IS 100.

B 25

B 26

OPEN (UNIT=11, FILE= 'MINERALS.DATA' , STATUS= ' OLD')

B 27

DO $26 \mathrm{M}=1,100$

B 28

READ $(11,27, E N D=7)$ MNAME (M) , NMINO (M) ,THMIN(M) ,LKTOM(M) ,DHMIN(M)

B 29

1,MFLAG (M) , SIMIN(M)

B 30 
27 FORMAT $(\mathrm{A} 8,2 \mathrm{X}, \mathrm{I} 2,3 \mathrm{X}, 3 \mathrm{Al} 0,5 \mathrm{X}, \mathrm{Il}, 9 \mathrm{X}, \mathrm{Al} 0) \quad$ B 31

$\mathrm{NO2}=\mathrm{NMTNO}$ (M)

IF (NO2.LE.5) GO TO 29

B 32

$\mathrm{NO} 2=5$

$29 \operatorname{READ}(11,28) \quad(\mathrm{LMIN}(\mathrm{M}, \mathrm{MO}), \mathrm{CMIN}(\mathrm{M}, \mathrm{MO}), \mathrm{MO}=\mathrm{NUM}, \mathrm{NO} 2)$

B 33

28 FORMAT $(5(\mathrm{I} 4, \mathrm{Al} 1))$

B 34

IF (NMINO(M) .LE.5.OR.NUM.EQ.6) GO TO 30

B 35

NUM $=6$

B 36

$\mathrm{NO2}=\mathrm{NMINO}$ (M)

B 37

GO TO 29

30 IF (MFLAG(M) .NE.1) GO TO 26

$\operatorname{READ}(11,31) \quad(\operatorname{AMIN}(M, M O), M O=1,5)$

B 38

B 39

B 40

B 41

31 FORMAT (5Al2)

B 42

26 CONTINUE

B 43

7 IMINERAL $=$ M-1

C

READ THERMODYNAMIC DATA OF PHREEQE.

C NOTE: THE DATA BLOCKS OF PHREEQE DATA CAN BE ARRNAGED IN ANY ORDER.

C

OPEN (UNIT=12, FILE= ' PHREEQE. DATA' , STATUS=' OLD')

48 RFAD $(12,11)$ KEYWORD

B 51

11 FORMAT (AB)

C

C

C

45 IF (KEYWORD. EQ.SUB (2)) GO TO 42

IF (KEYWORD. EQ.SUB(3)) GO TO 44

READ $(12,43$, END $=50)$ LINE

43 FORMAT (A80)

READ (LINE,11) KEYWORD

GO TO 45

46 LREAD=LREAD+1

IF (L.READ. EQ.2) REIURN

GO TO 48

C

C

C

$44 \mathrm{DO} 80 \mathrm{JL}=1,250$

READ $(12,51)$ NOUSEI

IF (NOUSEl.EQ.0)GO TO 46

READ $(12,52)$ NOUSE2 , NOUSE3 , NOUSE4 , NOUSE5 , NOUSE6

51 FORMAT (I3)

52 FORMAT (A8, 2X, I3 ,2Il, Fl0.3,//)

IF (NOUSE3.GT.6) READ $(22,53$ )

53 FORMAT (1X)

IF (NOUSEI.GT.30)GO TO 80

SPEC (NOUSE1) =NOUSE2

OPV (NOUSE] ) =NOUSE6

80 CONTINUE
B 53

B 54

B 55

B 56

B 57

B 58

B 59

B 60

B 61

B 62

B 63

B 64

B 65

B 66

B 67

B 68

B 69

B 70

B 71

B 72

B 73

B 74

B 75

B 76

B 77

B 78

B 79

B 80 
$\begin{array}{lll}\text { GO TO } 46 & \text { B } & 81\end{array}$

$\begin{array}{lll}\text { C } & \text { B } 82\end{array}$

$\begin{array}{ll}\text { C READ ELEMENTS DATA BLOCK. } & \text { B } 83\end{array}$

C

$42 \mathrm{DO} 8 \mathrm{JL}=1,50$

B 84

$\operatorname{READ}(12,9) \operatorname{ICOLI}(0), \operatorname{ICOL} 2(0), \operatorname{ICOL} 3(0), \operatorname{ICOL} 4(0) \quad$ B 86

9 FORMAT (A8, $2 \mathrm{X}, \mathrm{I} 2,3 \mathrm{X}, \mathrm{F} 10.0,5 \mathrm{X}, \mathrm{A} 8) \quad$ B 87

IF (ICOL2 (0) .GT.30) GO TO $8 \quad$ B 88

IF (ICOL2 (0).NE.0)GO TO $100 \quad$ B 89

JCOL $=\mathrm{JL}-1 \quad$ B 90

GO TO $46 \quad$ B 91

100 ICOLl (ICOL2 $(0))=$ ICOLl (0) $\quad$ B 92

ICOL $2(\operatorname{ICOL} 2(0))=\operatorname{ICOL} 2(0) \quad$ B 93

$\operatorname{ICOL} 3(\operatorname{ICOL} 2(0))=\operatorname{ICOL} 3(0) \quad$ B 94

ICOL4 $($ ICOL $2(0))=$ ICOL4 $(0) \quad$ B 95

8 CONTINUE

B 96

50 STOP $\quad$ B 97

$\begin{array}{lr}\text { C } * * * * * * * * * * * & \text { B } 98\end{array}$

ENTRY LISTM $\quad$ B 99

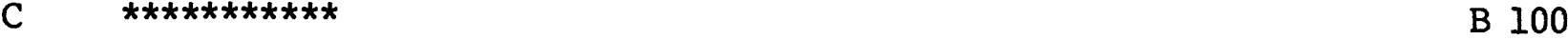

B 101

C THIS SUBROUTINE FORMATS AND PRINTS A TABLE OF MASTER

$\begin{array}{lll}C & \text { SPECIES AND ELEMENTS. } & \text { B } 103\end{array}$

DO $200 \mathrm{MO}=1,3 \quad$ B 105

ICOLl (MO) $=$ NONE $\quad$ B 106

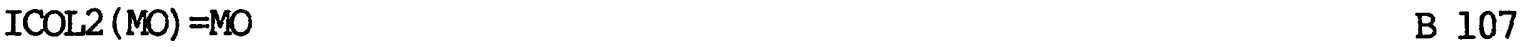

$\begin{array}{lr}\operatorname{ICOL3}(\mathrm{MO})=0.0 & \text { B } 108\end{array}$

$\operatorname{ICOL} 4(\mathrm{MO})=\mathrm{NONE} \quad$ B 109

$\begin{array}{lr}\mathrm{OPV}(\mathrm{MO})=0.0 & \mathrm{~B} 110\end{array}$

200 CONTINUE $\quad$ B 111

$\operatorname{ICOL3}(3)=18.0152 \quad$ B 112

$\operatorname{SPEC}(1)=' \mathrm{H}+\quad$ ' 113

$\operatorname{SPEC}(2)=$ 'E- $\quad$ '

$\operatorname{SPEC}(3)=$ 'H2O $\quad$ ' B 115

WRITE $(1,201) \quad$ B 116

201 FORMAT (/34X, 'INPUT FORMULA',/,34X, 'CORRESPONDING' ,5X, 'MASTER',/ B 117

1,1X, 'ELEMENIS' ,5X, '\#' ',9X, 'GEW' ,10X, 'TO GEW' ,9X, 'SPECIES' ,6X, 'OPV' B 118

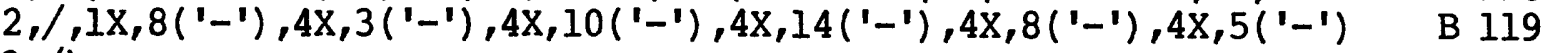

$3, /) \quad$ B 120

DO $203 \mathrm{MO}=1,30 \quad$ B 121

IF (ICOL2(MO) .EQ.0)GO TO $203 \quad$ B 122

$\operatorname{WRITE}(1,202) \operatorname{ICOLl}(\mathrm{MO}), \operatorname{ICOL} 2(\mathrm{MO}), \operatorname{ICOL} 3(\mathrm{MO}), \operatorname{ICOL4}(\mathrm{MO}), \operatorname{SPEC}(\mathrm{MO}) \quad$ B 123

$1, O P V(M O) \quad$ B 124

203 CONTINUE $\quad$ B 125

202 FORMAT ( $1 \mathrm{X}, \mathrm{A} 8,4 \mathrm{X}, \mathrm{I2}, 5 \mathrm{X}, \mathrm{F} 10.4,8 \mathrm{X}, \mathrm{A} 8,6 \mathrm{X}, \mathrm{A} 8,4 \mathrm{X}, \mathrm{SP}, \mathrm{F} 4.1, \mathrm{SS}) \quad$ B 126

$\begin{array}{ll}\text { RETURN } & \text { B } 127\end{array}$

$\begin{array}{lr}\text { END } & \text { B } 128\end{array}$

C

SUBROUTINE REF (IIINE,JOPT, JOPEN)

$\begin{array}{ll}\text { C } & 1 \\ \text { C } & 2\end{array}$ 


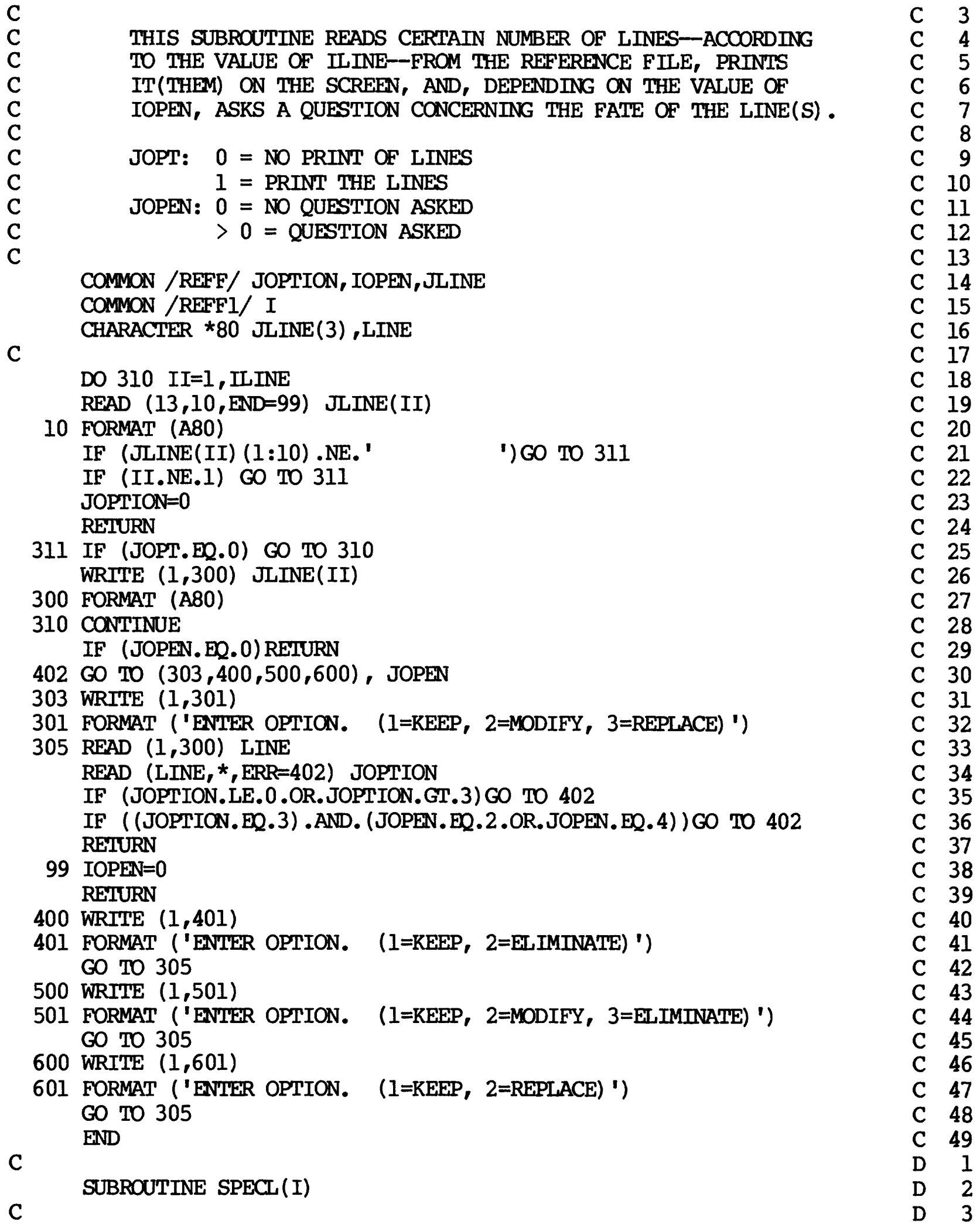


C THIS SUBROUTINE CHECKS FOR SPECIAL CHARACTERS 'EXIT' AND 'LIST'

C COMMON /EE/ EXIT,LIST,LINE,JFLAG

LOGICAL EXIT,LIST

C

CHARACTER *80 LINE

D 4

D 5

D 6

D 7

D 8

EXIT=.FALSE.

LIST=.FALSE.

D 9

IF (I.EQ.0) RETURN

D 10

IF ((LINE(1:4).EQ.'LIST' .OR.LINE( $1: 4)$.EQ.'list') .AND. (I.EQ.2.OR.

D 11

D 12

II.EQ.3)) LIST=.TRUE.

D 13

IF ((LINE(1:4) .EQ.'EXIT' .OR.LINE(1:4) .EQ.'exit') .AND. (I.EQ.1.OR.

D 14

II.EQ.3)) EXIT=.TRUE.

D 15

REIURN

END

C

LOGICAL FUNCTION OK

D 16

D 17

D 18

E 1

C

THIS SUBROUTINE ASKS WHETHER IT IS O.K.

E 2

C

C

COMMON /PN/ NFLAG

E 3

E 4

LOGICAL ANSWER, YN

E 5

E 6

C

WRITE $(1,10)$

10 FORMAT ('O.K.?')

NFLAG $=0$

E 7

E 8

E 9

OK=. TRUE.

E 10

E 11

ANSWER=YN()

IF (ANSWER) REIURN

E 12

E 13

NFLAG $=1$

E 14

OK=.FALSE.

E 15

RETURN

E 16

END

E 17

E 18

C

C

THIS SUBROUTINE READS VALUES FROM THE TERMINAL AND CHECKS TO MAKE

F 1 SURE THAT IT IS PROPER

C

SUBROUTINE QUESTA ( *,Jl, CHARl, Ll, STRING, Fl, Kl, MI)

COMMON /REFF/ JOPTION, IOPEN, JLINE

COMMON /PN/ NFLAG

COMMON /EE/ EXIT,LIST,LINE,JFLAG

CHARACTER * $(*)$ STRING

CHARACTER *80 LINE, JLINE(3)

CHARACTER *72 QUESTION

CHARACTER *40 FMP

CHARACTER * 16 CHAR, CHARI

CHARACTER *4 F,FI

CHARACTER *2 FO(16)

F 2

F 3

F 4

F 5

F 6

F 7

F 8

F 9

F 10

F 11

F 12

F 13

F 14

LOGICAL EXIT,LIST, NONB

F 15

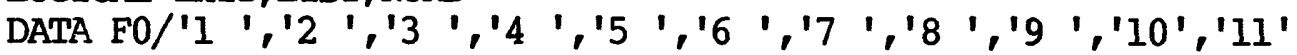

F 16

F 17 


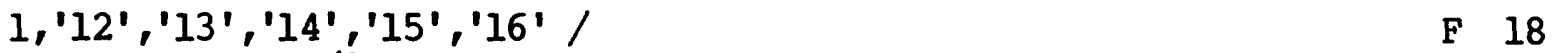

DATA QUESTION /'KEEP THE OLD VALUE? (HIT <REIURN> IF YOU DO; IF NO F 19

$\mathrm{C}$ IT, REENTER THE DATA) $\%$

F 20

C

$\mathrm{K}=0 \Rightarrow$ STRING

$\mathrm{K}=1 \Rightarrow \mathrm{REAL}$

$\mathrm{K}=2 \Rightarrow$ INIEGER

F 21

C

C

C

IF (Fl.EQ. 'ABO') $\mathrm{Fl}=1 / \mathrm{A} 80^{\prime}$

GO TO 50

C

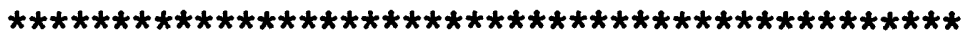

ENIRY QUESTB ( $*$, J, CHAR, L, IVAL, F, IMIN, IMAX, M)

C

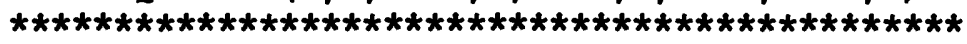

$\mathrm{K}=2$

GO TO 100

C

$50 \mathrm{~J}=\mathrm{J} 1$

CHAR=CHARI

$\mathrm{F}=\mathrm{Fl}$

$\mathrm{K}=\mathrm{K} \mathrm{I}$

$\mathrm{L}=\mathrm{LI}$

$M=\mathrm{MI}$

C

100 IF (J.GT.0.AND.J.LT.10) I=1

IF (J.GE.10.AND.J.LT.100) I=2

IF (J.GE.100) I=3

IF (NFLAG.GT.0.OR.JOPTION.EQ.2) GO TO 30

IF (J.GT.0) GO TO 10

FMI $=$ ' $\left(/,{ }^{\prime}\right.$ 'INPUT ' ', A'//FO(L)//')'

WRITE $(1, F M T)$ CHAR

GO TO 300

$10 \mathrm{FMI}=$ '(/,' 'INPUT '',A'//FO(L)//',''('',I'//FO(I)//',' ')'')'

WRITE ( 1, FMI) CHAR, J

GO TO 300

30 IF (J.GT.0) GO TO 40

FMI =' $\left(/,{ }^{\prime}\right.$ OLD ' ' $, A^{\prime} / / F O(L) / / 1, '$ '=' ', '//F//',$\left./, A 72\right)$ '

IF (K. EQ.2) WRITE ( 1, FMT) CHAR, IVAL,QUESTION

IF (K.NE.2) WRITE ( 1 ,FMI) CHAR, STRING,QUESTION

GO TO 300

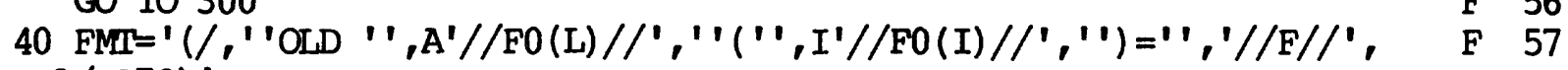

$1 /, \mathrm{A} 72)$ '

IF (K.EQ.2) WRITE (1,FMI) CHAR, J, IVAL, QUESTION

IF (K.NE.2) WRITE ( 1 ,FMT) CHAR,J, STRING,QUESTION

C

C READ RESPONSE

C

300 JFLAG $=0$

READ $(1,105)$ LINE

105 FORMAT(A80)

C 


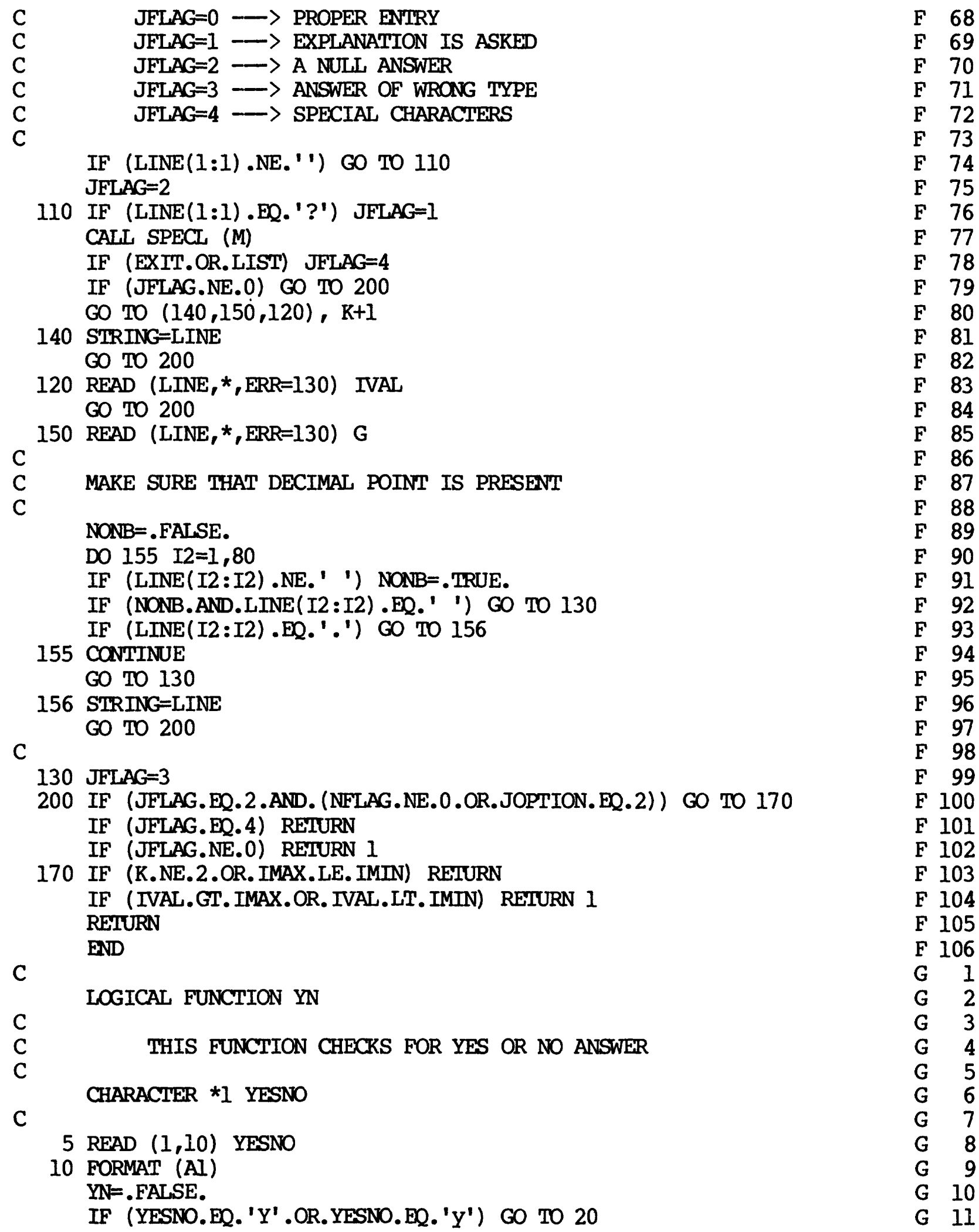


IF (YESNO.EQ.' $N$ '.OR.YESNO.EQ.' 'n') REIURN $\quad$ G 12

WRITE $(1,30) \quad$ G 13

30 FORMAT ('PLEASE ANSWER ''Y'' OR ''N''.') $\quad$ G 14

GO TO $5 \quad$ G 15

$20 \mathrm{YN}=$. TRUE. $\quad$ G 16

RETURN $\quad$ G 17

$\begin{array}{lll}\text { END } & \text { G } & 18\end{array}$

C

$\begin{array}{lll}\text { SUBROUTINE OPEN(ITIME) } & \text { H } & 2\end{array}$

H 3

C THIS SUBROUTINE GIVES THE USER A CHOICE OF CHOOSING A $\quad$ H 4

C REFERENCE FILE OR NOT TO USE IT AT ALL. IF THE $\quad$ H 5

C REFERENCE FILE IS DESIRED, IT OPENS THE FILE AND

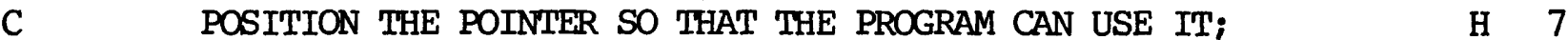

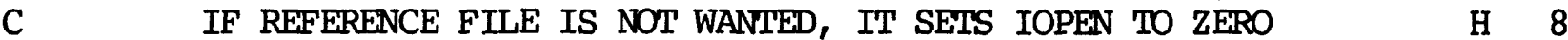

$\begin{array}{llr}\text { C AND RETURN TO 'MAIN. } & \text { H } & 9\end{array}$

H 10

COMMON /REFF/ JOPTION, IOPEN, JLINE $\quad$ H 11

CHARACTER *36 TREAD $\quad$ H 12

CHARACTER *80 LINE, JLINE(3) $\quad$ H 13

SAVE TREAD, KOPEN $\quad$ H 14

$\begin{array}{lll}\text { LOGICAL YN } & \text { H } & 15\end{array}$

$\begin{array}{lr}\mathrm{C} & \mathrm{H} \quad 16\end{array}$

$\begin{array}{ll}\text { ITIME=ITIME+1 } & \text { H } 17\end{array}$

IF (ITIME.EQ.1.OR.KOPEN.EQ.0)GO TO $100 \quad$ H 18

120 WRITE $(1,110) \quad$ H 19

110 FORMAT ( $/$, 'DO YOU WISH TO USE THE SAME REFERENCE FILE?') $\quad$ H 20 IF (.NOT. IN()) GO TO $100 \quad$ H 21

CLOSE (UNIT=13) $\quad$ H 22

GO TO $25 \quad$ H 23

100 WRITE $(1,10) \quad$ H 24

10 FORMAT (/,' ENTER REFERENCE FILE NAME: (HIT 〈CR> TO OMIT) ') $\quad$ H 25 READ $(1,20)$ TREAD $\quad$ H 26

20 FORMAT (A36) $\quad$ H 27

IF (TREAD(1:1).NE.' ')GO TO $25 \quad$ H 28

IOPEN $=0 \quad$ H 29

GO TO $30 \quad$ H 30

25 OPEN (UNIT=13,FILE=TREAD, STATUS=' OLD' ) H 31

$\begin{array}{lll}I O P E N=1 & \text { H } 32\end{array}$

30 KOPEN=IOPEN $\quad$ H 33

$\begin{array}{lll}\text { RETURN } & \text { H } & 34\end{array}$

$\begin{array}{lll}\text { END } & \text { H } 35\end{array}$ 
Attachment E. - Minerals file read by PHRQINPT as logical file unit 11 . 


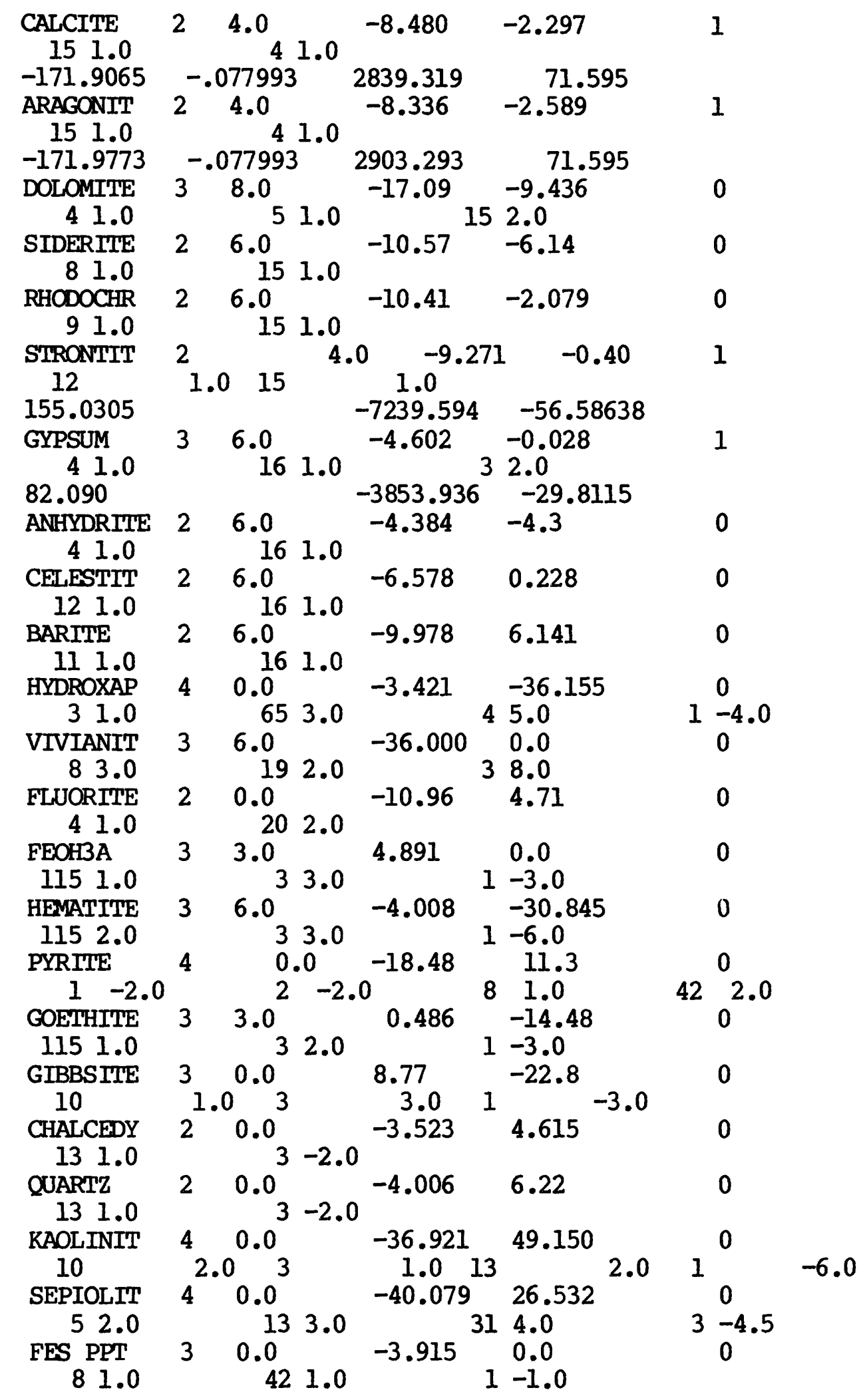




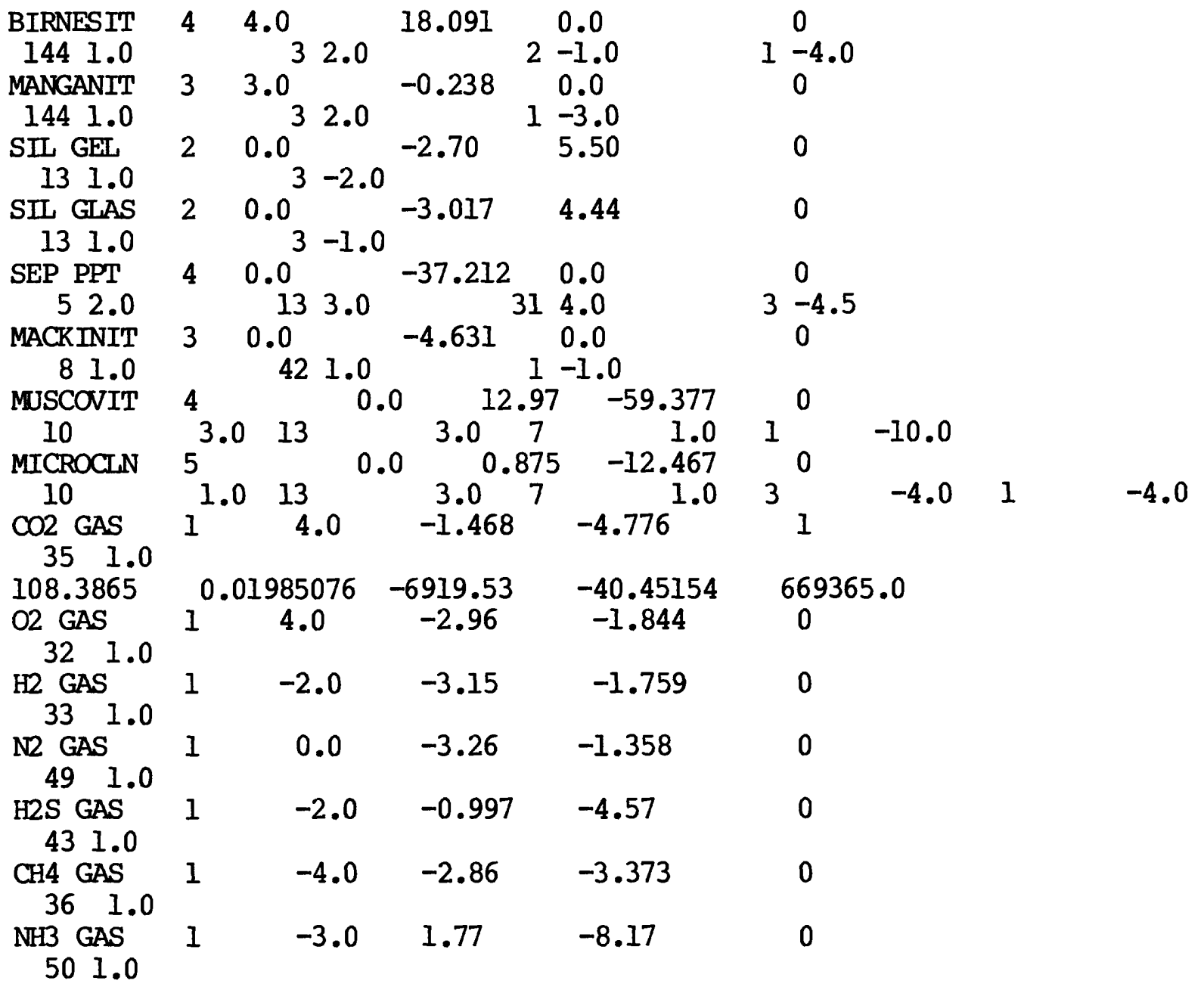




\section{Attachment F. - PHREEQE data file read by PHRQINPT as logical file unit 12 .}




\begin{tabular}{|c|c|c|c|}
\hline \multicolumn{4}{|c|}{ ELEMENTS } \\
\hline $\mathrm{CA}$ & 4 & 40.08 & $\mathrm{CA}+2$ \\
\hline MG & 5 & 24.305 & $M G+2$ \\
\hline $\mathrm{NA}$ & 6 & 22.9898 & NAt \\
\hline $\mathrm{K}$ & 7 & 39.0983 & $\mathrm{~K}+$ \\
\hline $\mathrm{FE}$ & 8 & 55.847 & $\mathrm{FE}+2$ \\
\hline MN & 9 & 54.9380 & $\mathrm{MN}+2$ \\
\hline AL & 10 & 26.9815 & $\mathrm{AL}+3$ \\
\hline $\mathrm{BA}$ & 11 & 137.33 & $\mathrm{BA}+2$ \\
\hline SR & 12 & 87.62 & $\mathrm{SR}+2$ \\
\hline SI & 13 & 60.0843 & SIO2 \\
\hline $\mathrm{CL}$ & 14 & 35.453 & $\mathrm{CL}-$ \\
\hline C & 15 & 44.0098 & $\mathrm{CO} 2$ \\
\hline $\mathbf{S}$ & 16 & 96.06 & SO4-2 \\
\hline $\mathrm{N}$ & 17 & 62.0049 & $\mathrm{NO3}-$ \\
\hline B & 18 & 10.81 & B \\
\hline $\mathrm{P}$ & 19 & 94.9714 & $\mathrm{PO4}-3$ \\
\hline $\mathbf{F}$ & 20 & 18.9984 & F- \\
\hline LI & 21 & 6.941 & LIt \\
\hline $\mathrm{BR}$ & 22 & 79.904 & BR- \\
\hline
\end{tabular}

\section{SPECIES}

\begin{tabular}{|c|c|c|c|c|c|c|}
\hline $\begin{array}{l}\mathrm{H}+ \\
0.0 \\
\quad 1 \\
2\end{array}$ & $\begin{array}{l}1001.0 \\
0.0\end{array}$ & 0.0 & 9.0 & & & 0.0 \\
\hline $\begin{array}{l}\mathrm{E}- \\
0.0 \\
21.0 \\
3\end{array}$ & $\begin{array}{l}100-1.0 \\
0.0\end{array}$ & 0.0 & 0.0 & & & 0.0 \\
\hline $\begin{array}{l}\mathrm{H} 2 \mathrm{O} \\
0.0 \\
31.0 \\
4\end{array}$ & $\begin{array}{l}1000.0 \\
0.0\end{array}$ & 0.0 & 0.0 & & & 0.0 \\
\hline $\begin{array}{l}\text { CA+2 } \\
0.0 \\
41.0 \\
5\end{array}$ & $\begin{array}{l}1012.0 \\
0.0\end{array}$ & 0.0 & 6.0 & 5.0 & 0.165 & 0.0 \\
\hline $\begin{array}{l}\text { MG+2 } \\
0.0 \\
5 \\
5\end{array}$ & $0_{0.0}^{1012.0}$ & 0.0 & 8.0 & 5.5 & 0.20 & 0.0 \\
\hline $\begin{array}{l}\text { NAt } \\
0.0 \\
6 \\
7 \\
7\end{array}$ & $0.0^{101} 1.0$ & 0.0 & 4.0 & 4.0 & 0.075 & 0.0 \\
\hline $\begin{array}{ll}\mathrm{K}+ & \\
0.0 & \\
7 & 1.0\end{array}$ & $0.0^{101} 1.0$ & 0.0 & 3.0 & 3.5 & 0.015 & 0.0 \\
\hline
\end{tabular}




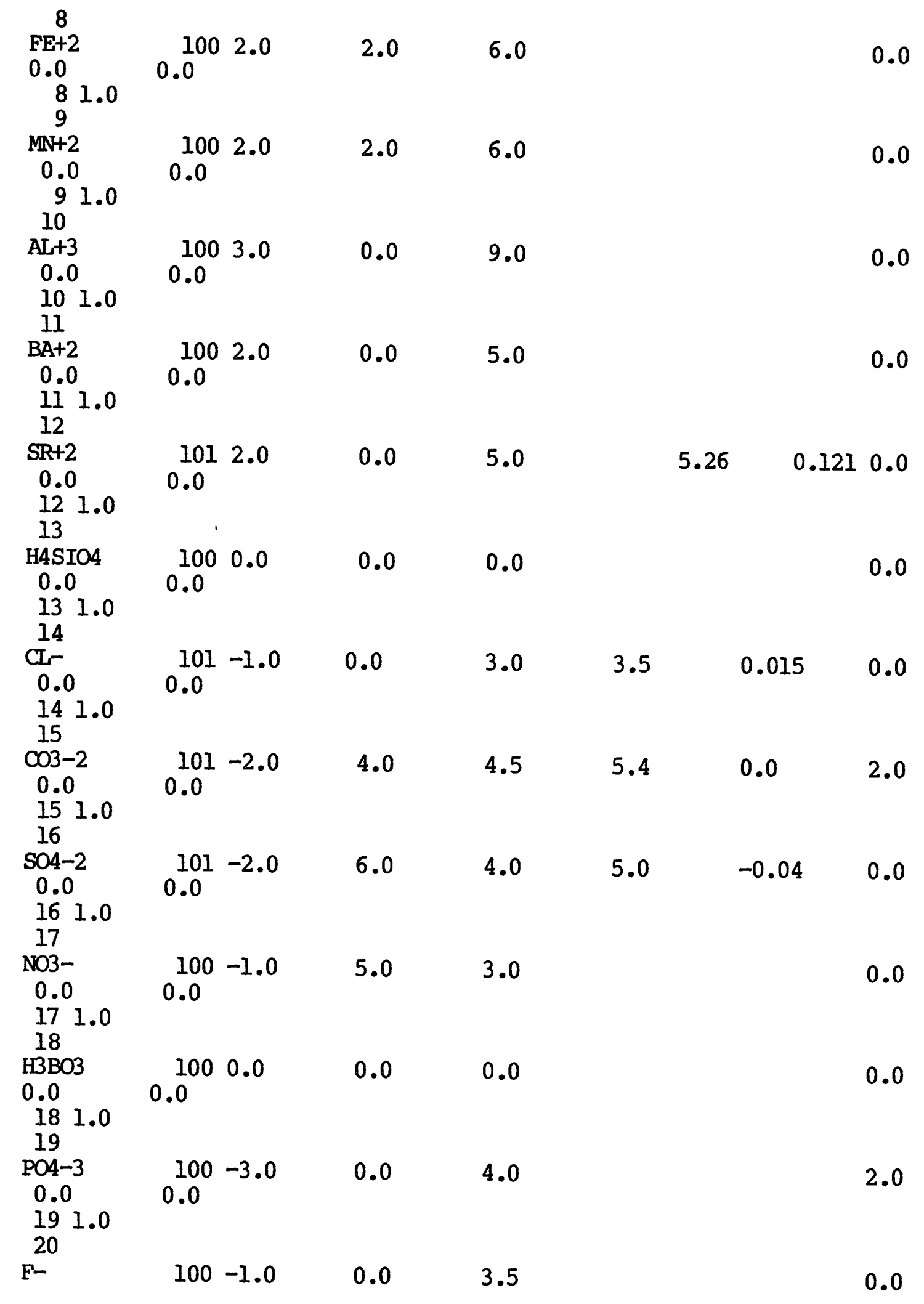




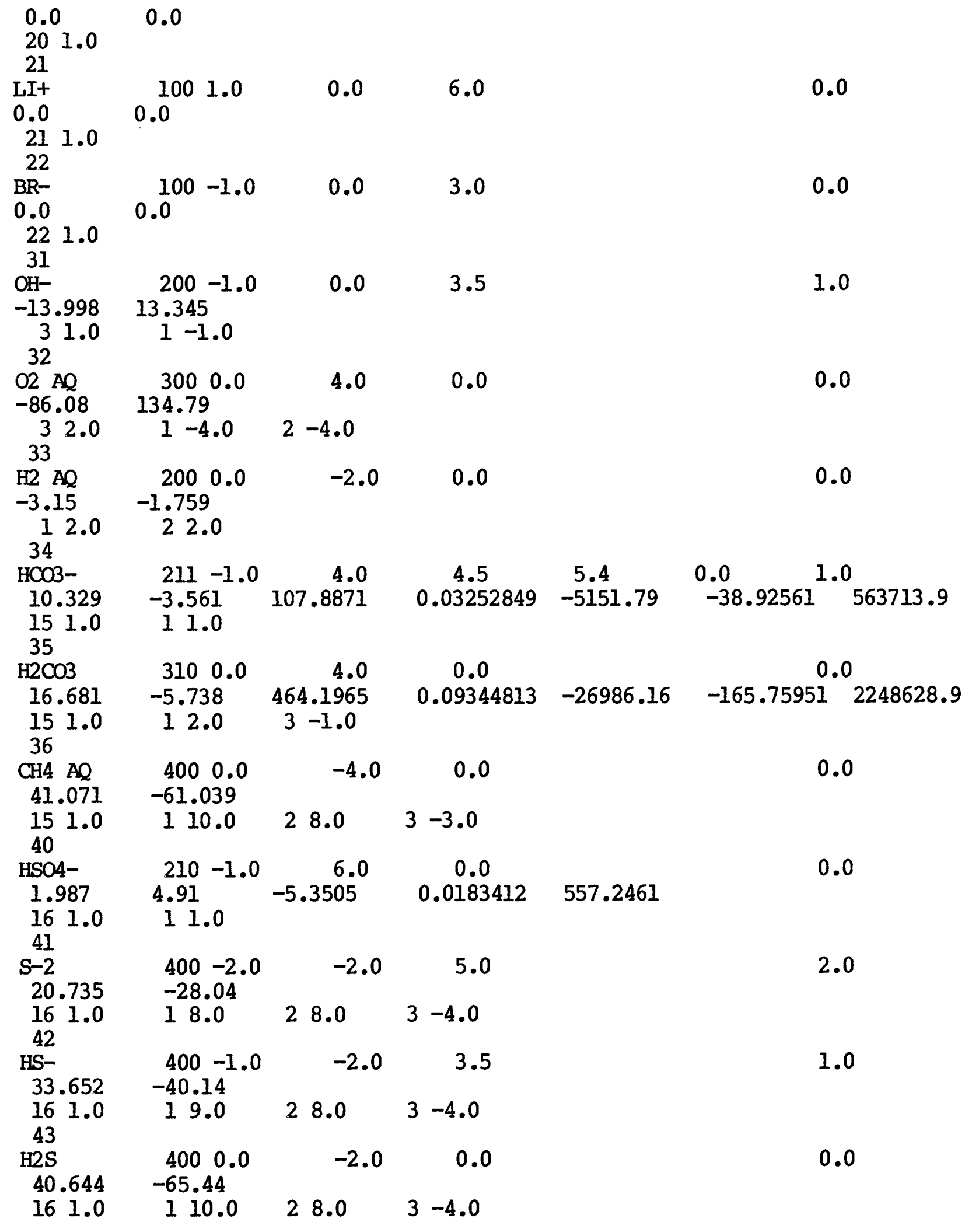




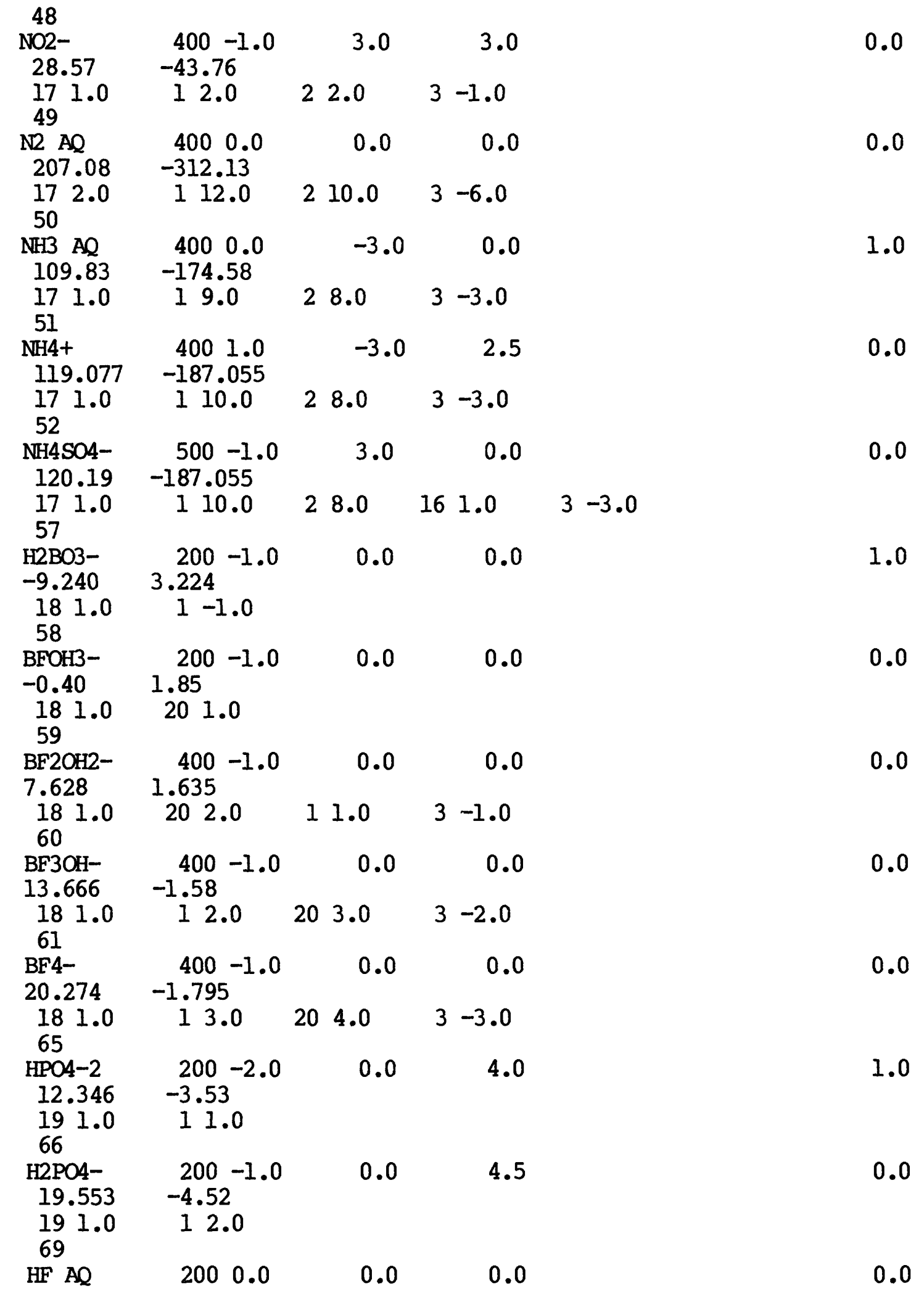




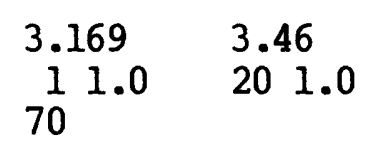

$$
\begin{array}{ccccc}
\text { HF2- } & 200-1.0 & 0.0 & 0.0 & 0.0 \\
3.749 & 4.55 & & & \\
11.0 & 202.0 & & & \\
75 & & & & \\
\text { CAOH+ } & 3001.0 & 0.0 & 0.0 & 1.0 \\
-12.598 & 14.535 & & & \\
41.0 & 31.0 & 1-1.0 & &
\end{array}
$$

76

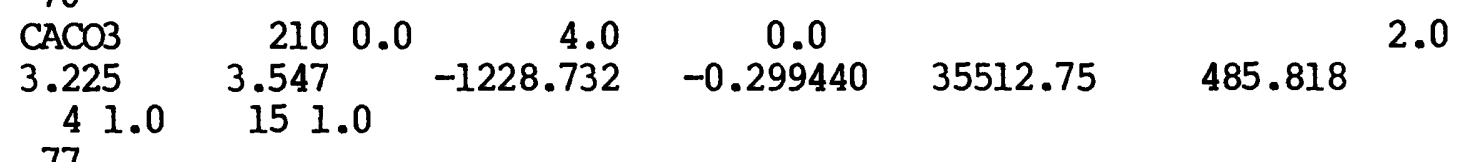

77

$\begin{array}{ccccccc}\text { CAHCO3+ } & 3111.0 & 4.0 & 0.0 & 5.4 & 0.0 & 1.0 \\ 11.435 & -0.869 & 1317.0071 & 0.34546894 & -39916.84 & -517.70761 & 563713.9 \\ 41.0 & 151.0 & 11.0 & & & & \\ 78 & & & & & 0.0 \\ \text { CASO4 } & 200 & 0.0 & 6.0 & 0.0 & & \end{array}$

$2.309 \quad 1.470$

$41.0 \quad 161.0$

79

$\begin{array}{lcccc}\text { CAPO4- } & 200-1.0 & 0.0 & 0.0 & 2.0 \\ 6.459 & 3.100 & & \\ 41.0 & 191.0 & & & 0.0\end{array}$

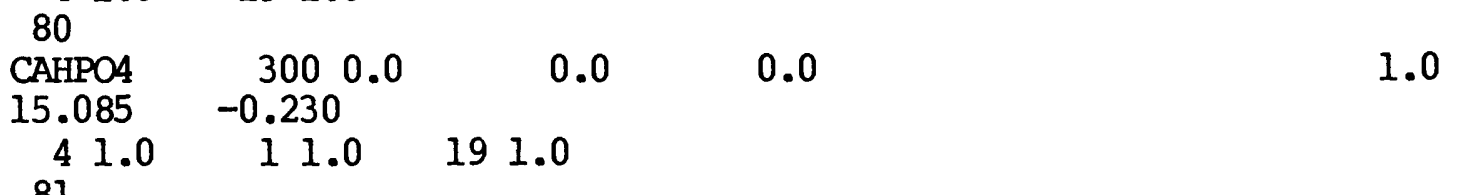

81

CAH2PO4+ $3001.0 \quad 0.0$

$20.961-1.120$

$\begin{array}{llll}41.0 & 12.0 & 191.0\end{array}$

82

CAF+ $\quad 2001.0 \quad 0.0$

$0.940 \quad 3.798$

$\begin{array}{ll}41.0 & 201.0\end{array}$

85

MGOH+ $\quad 3001.0$

$-11.794 \quad 15.419$

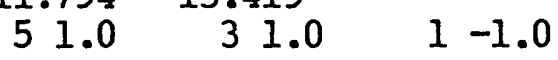

86

MGCO3 $210 \quad 0.0 \quad 4.0$

$2.981 \quad 2.535 \quad-32.172$

$51.0 \quad 151.0$

87

\begin{tabular}{lllllll} 
MGHCO3+ & 3101.0 & 4.0 & 0.0 & \multicolumn{2}{c}{1.0} \\
11.397 & -2.775 & 48.6721 & 0.03252849 & -2614.335 & -18.00263 & 563713.9
\end{tabular}

$51.0 \quad 11.0 \quad 151.0$ 


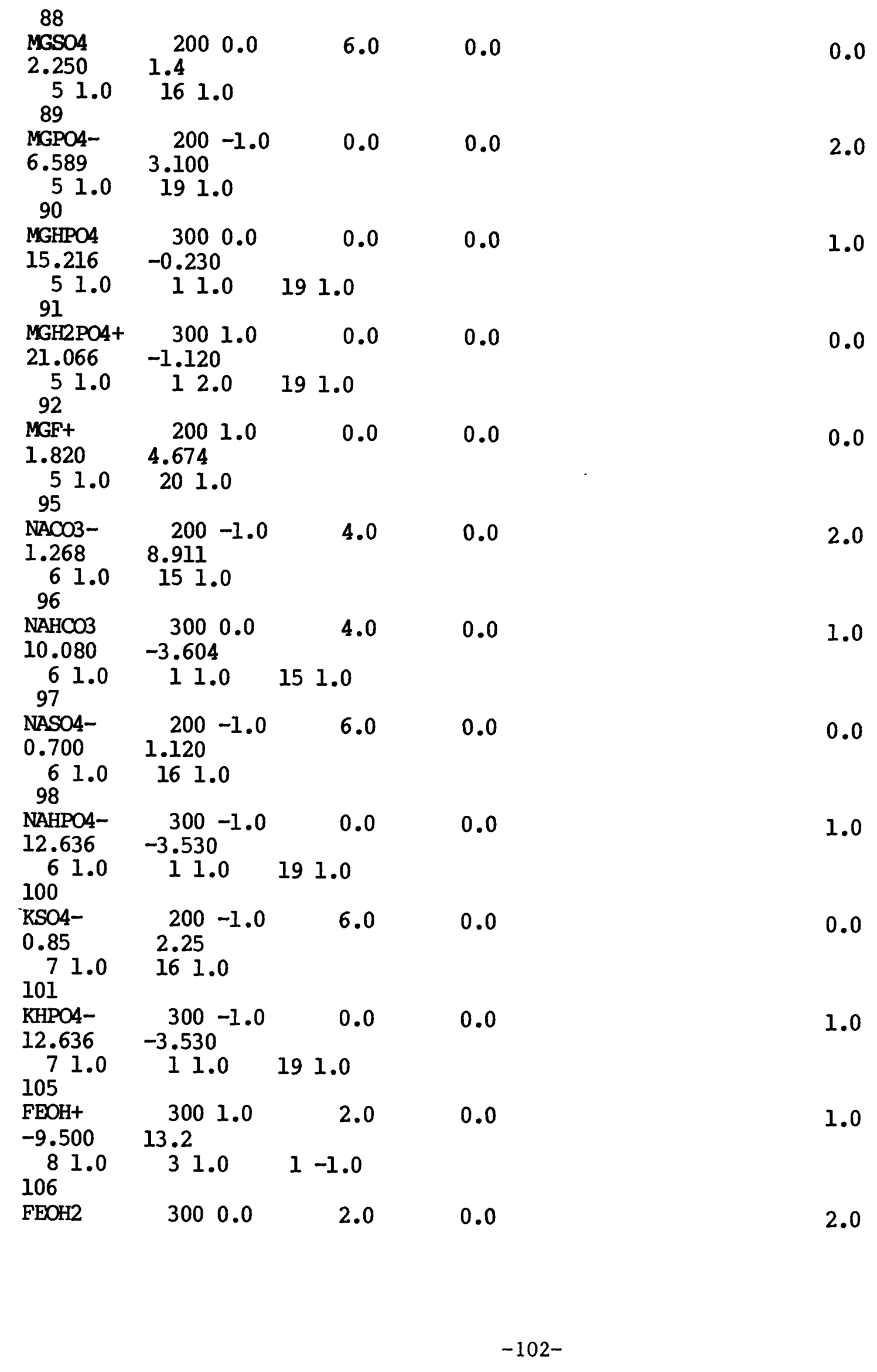




\begin{tabular}{|c|c|c|c|c|c|}
\hline $\begin{array}{r}-20.570 \\
81.0 \\
107\end{array}$ & $\begin{array}{r}28.565 \\
32.0\end{array}$ & $1-2.0$ & & & \\
\hline $\begin{array}{l}\text { FEOH3- } \\
-31.000\end{array}$ & $\begin{array}{l}300-1.0 \\
30.300\end{array}$ & 2.0 & 0.0 & & 3.0 \\
\hline $\begin{array}{r}81.0 \\
108\end{array}$ & 33.0 & $1-3.0$ & & & \\
\hline $\begin{array}{l}\text { FESO4 } \\
2.25 \\
81.0 \\
109\end{array}$ & $\begin{array}{l}2000.0 \\
3.23 \\
161.0\end{array}$ & 8.0 & 0.0 & & 0.0 \\
\hline $\begin{array}{l}\text { FE(HS) } 2 \\
76.250\end{array}$ & $\begin{array}{r}500 \quad 0.0 \\
-120.280\end{array}$ & -2.0 & 0.0 & & 2.0 \\
\hline $\begin{aligned} 81.0 \\
110^{1.0}\end{aligned}$ & 162.0 & 118.0 & 216.0 & $3-8.0$ & \\
\hline $\begin{array}{l}\text { FE(HS) 3- } \\
111.937\end{array}$ & $\begin{aligned} & 500-1.0-180.420 \\
&-180.40\end{aligned}$ & -4.0 & 0.0 & & 3.0 \\
\hline $\begin{array}{l}81.0 \\
111\end{array}$ & 163.0 & 127.0 & 224.0 & $3-12.0$ & \\
\hline $\begin{array}{c}\text { FEHPO4 } \\
15.946 \\
81.0 \\
112\end{array}$ & $\begin{array}{c}3000.0 \\
-3.530 \\
11.0\end{array}$ & $\begin{array}{rl} & 2.0 \\
19 & 1.0\end{array}$ & 0.0 & & 1.0 \\
\hline $\begin{array}{l}112 \\
\text { FEH2PO4+ } \\
22.253\end{array}$ & $\begin{array}{l}3001.0 \\
-4.520\end{array}$ & 2.0 & 0.0 & & 0.0 \\
\hline $\begin{aligned} 81.0 \\
115\end{aligned}$ & 12.0 & 191.0 & & & \\
\hline $\begin{array}{l}F E+3 \\
-13.032 \\
81.0 \\
116\end{array}$ & $\begin{array}{l}2003.0 \\
10.0 \\
2-1.0\end{array}$ & 3.0 & 9.0 & & 0.0 \\
\hline $\begin{array}{l}\text { FEOH+2 } \\
-15.22\end{array}$ & $\begin{array}{rl}400 & 2.0 \\
20.4 & \end{array}$ & 3.0 & 0.0 & & 0.0 \\
\hline $\begin{aligned} 81.0 \\
117^{1.0}\end{aligned}$ & 31.0 & $2-1.0$ & $1-1.0$ & & \\
\hline $\begin{array}{l}\text { FEOH2+ } \\
-18.70 \\
81.0\end{array}$ & $\begin{array}{c}4001.0 \\
10.0 \\
32.0\end{array}$ & $\begin{array}{r}3.0 \\
1-2.0\end{array}$ & $\begin{array}{r}0.0 \\
2-1.0\end{array}$ & & 0.0 \\
\hline $\begin{array}{l}118 \\
\text { FEOH3 } \\
-26.63\end{array}$ & $\begin{array}{l}400 \quad 0.0 \\
10.0\end{array}$ & 3.0 & 0.0 & & 1.0 \\
\hline $\begin{array}{rl}8 & 1.0 \\
119 & \end{array}$ & 33.0 & $1-3.0$ & $2-1.0$ & & \\
\hline $\begin{array}{l}\text { FEOH4- } \\
-34.63\end{array}$ & $\begin{array}{r}400-1.0 \\
10.0\end{array}$ & 3.0 & 0.0 & & 2.0 \\
\hline $\begin{aligned} 81.0 \\
120\end{aligned}$ & 34.0 & $1-4.0$ & $2-1.0$ & & \\
\hline $\begin{array}{l}\mathrm{FE} 2 \mathrm{OH} 2+4 \\
-29.01\end{array}$ & $\begin{array}{l}4004.0 \\
33.5\end{array}$ & 6.0 & 0.0 & & 0.0 \\
\hline 82.0 & 32.0 & $1-2.0$ & $2-2.0$ & & \\
\hline
\end{tabular}


121

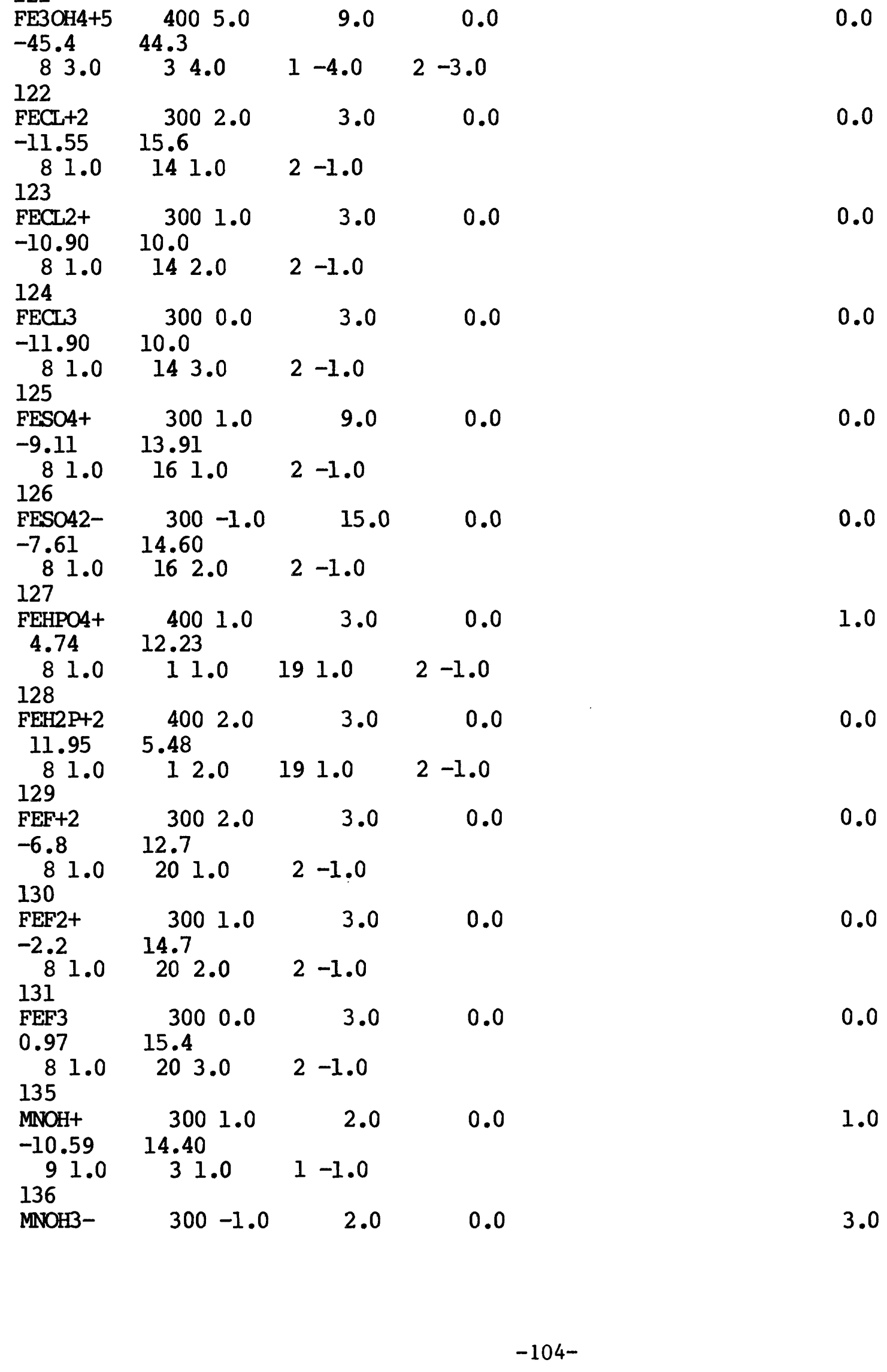




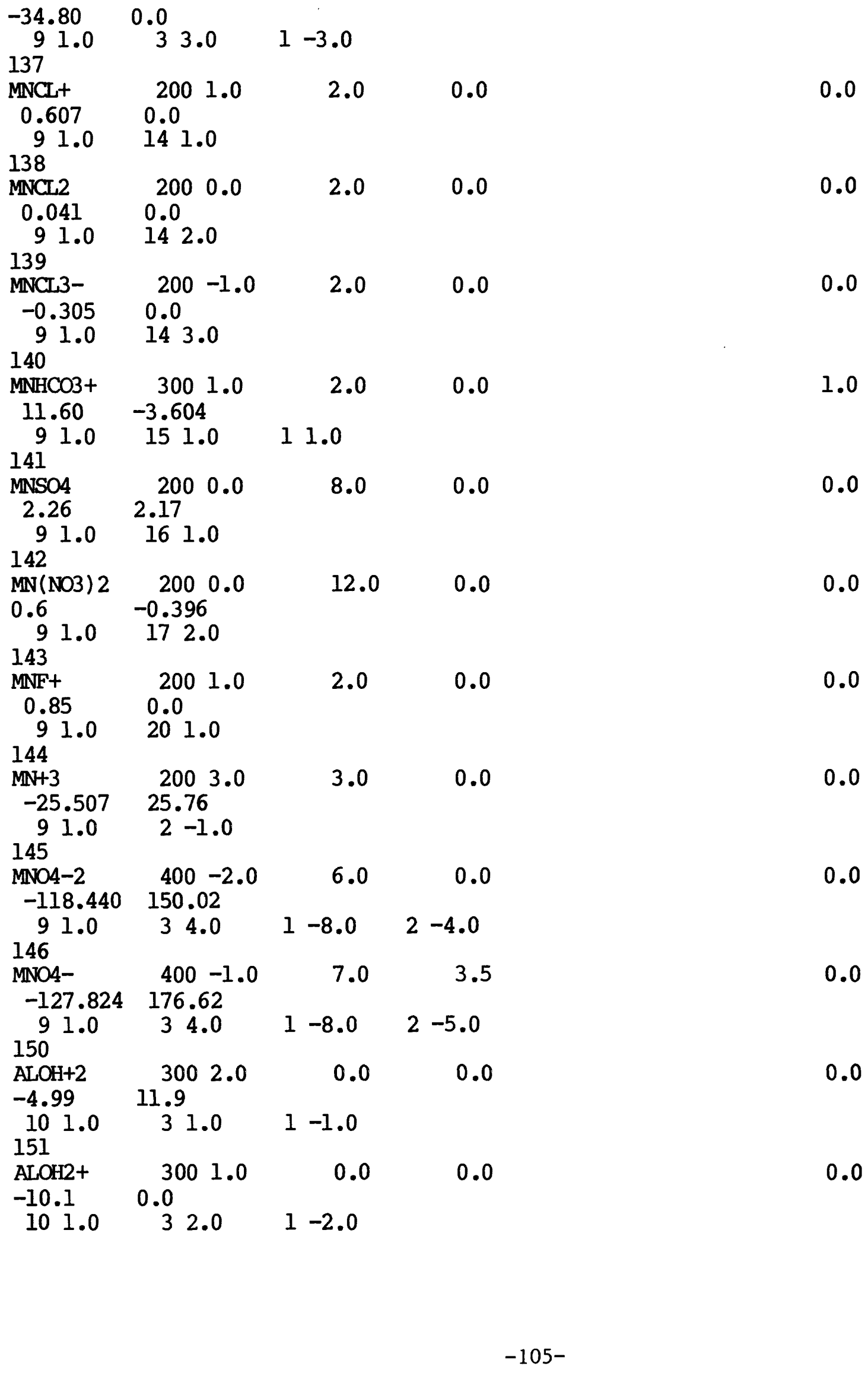




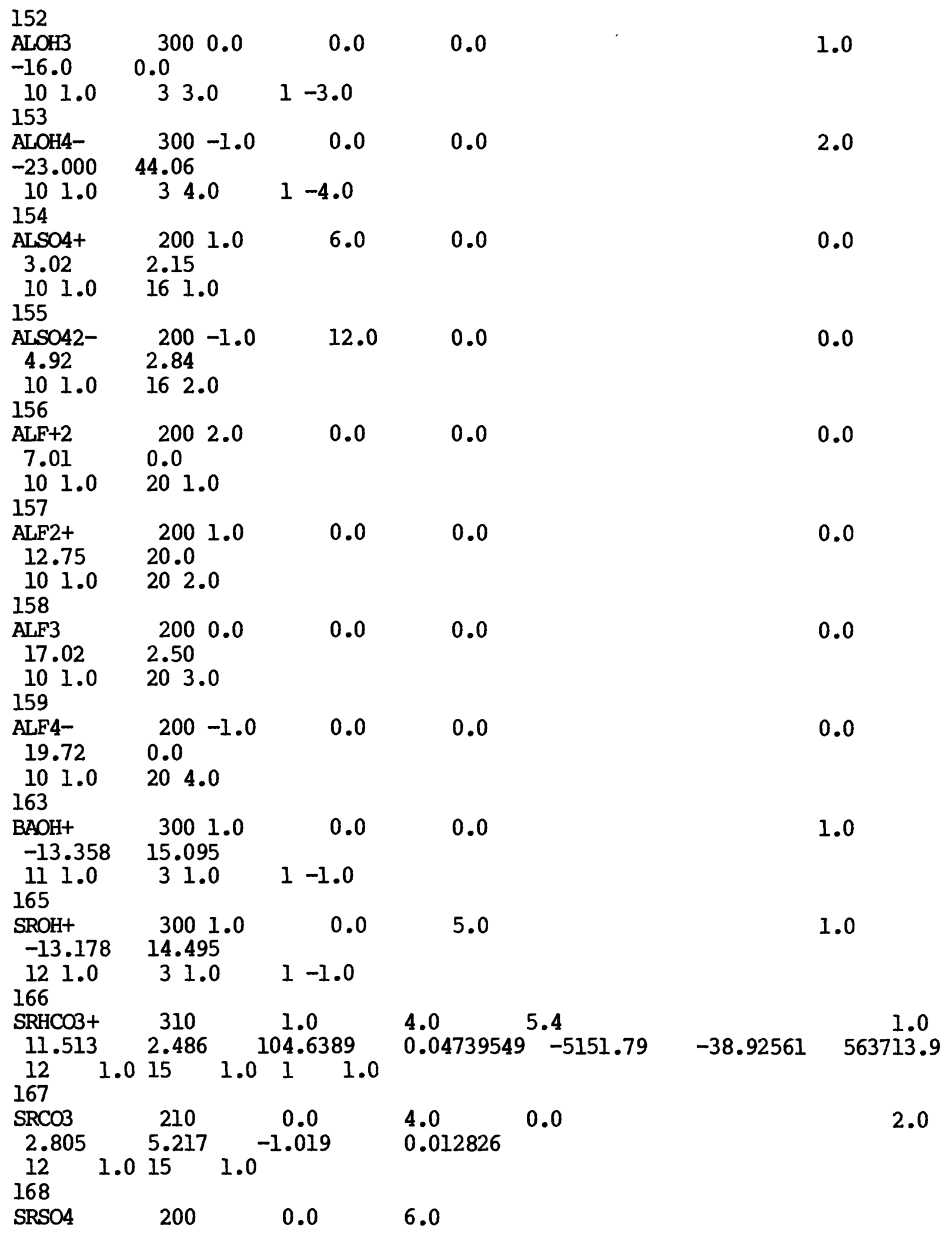


$\begin{array}{llll}2.55 & & 1.6 & \\ 170 & 1.0 & 16 & 1.0\end{array}$

H3SIO4- $\quad 210-1.0$

$\begin{array}{ccccc}-9.929 & 8.936 & 6.368 & -0.016346 & -3405.9 \\ 131.0 & 1-1.0 & & & \end{array}$

171

$\begin{array}{ccccc}\text { H2SIO4-2 } & 210-2.0 & 0.0 & 0.0 & \\ -21.617 & 29.717 & 39.478 & -0.065927 & -12355.1 \\ 131.0 & 1-2.0 & & & \end{array}$

172

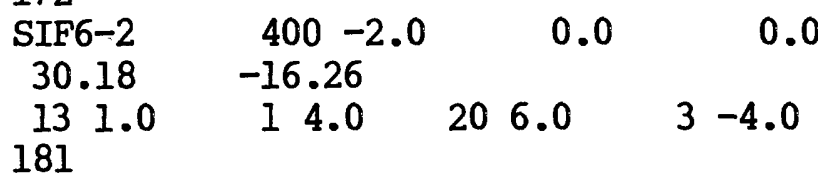

LISO4-

0.640

$21 \quad 1.0 \quad 161.0$

LOOK MIN

CALCITE 151.0

$200-1.0 \quad 6.0$

0.0

1.0

$-171.9065$

ARAGONIT

151.0 0.0

$-171.9773$

24.0

41.0

$-8.480 \quad-2.297$

1

DOLOMITE

41.0

$-.077993 \quad 2839.319$

71.595

24.0

41.0

$-.077993 \quad 2903.293$

71.595

SIDERITE

$\begin{array}{rll}81.0 & & 151.0 \\ \text { RHODOCHR } & 2 & 6.0\end{array}$

38.0

51.0

$-9.436$

0

91.0

STRONTIT

12

26.0

151.0

$2 \quad 151.0$

$1.0 \quad 15$

$\begin{array}{lll}4.0 & -9.271 & -0.40\end{array}$

2.0

155.0305

GYPSUM

41.0

82.090

$\begin{array}{llll}3 & 6.0 & -7239.594 & -56.586 \\ & -4.602 & -0.028\end{array}$

$-3853.936^{3} 2.0$

ANHYDRITE

41.0

161.0

CELESTII

121.0

BARITE

111.0

HYDROXAP

31.0

FLUORITE

41.0

CHALCEDY

131.0

6.0

$-4.384$

$-4.3$

161.0

$\begin{array}{lllll}2 & 6.0 & -6.578 & 0.228\end{array}$

6.141

0.0

0.0

161.0

$\begin{array}{llll}2 & 6.0 & -9.978\end{array}$ 161.0

$\begin{array}{llll}4 & 0.0 & -3.421\end{array}$

653.0

20.0

$-10.96$

$-36.155$

45.0

4.71

$1-4.0$

$2 \begin{array}{llll}20 & 2.0 & & \\ & 0.0 & -3.523 & 4.615\end{array}$

0 


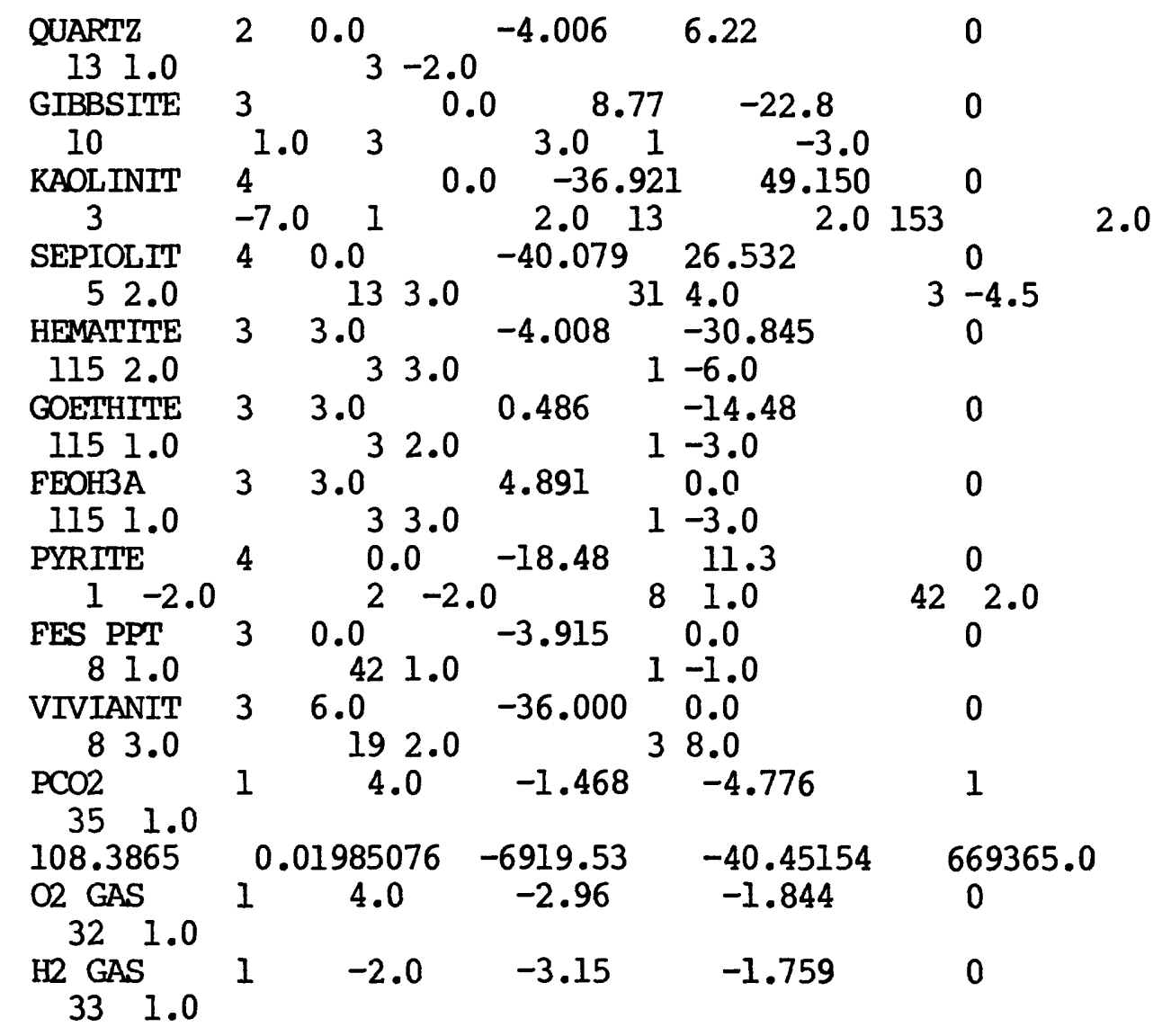

END 